Ks. Józef Wołczański

Kraków

\title{
Korespondencja abp. Józefa Teodorowicza z o. Włodzimierzem Ledóchowskim SJ $\mathrm{z}$ lat 1914-1937
}

\section{Wprowadzenie}

Konflikt pomiędzy abp. Józefem Teodorowiczem a o. prof. Pawłem Siwkiem SJ zrodzony na gruncie odmiennych poglądów na tzw. kwestię Konnersreuth, wywołał w latach 30. XX wieku rzecz jasna szeroki rezonans społeczny zwłaszcza w polskim środowisku kościelnym. Oto bowiem gorącą polemikę podjęło dwóch duchownych: zwierzchnik polskich Ormian obrządku katolickiego abp Józef Teodorowicz i znakomity uczony o utrwalonej już renomie na forum międzynarodowym o. prof. Paweł Siwek. O ile pierwszy z nich nie posiadał wystarczającego przygotowania merytorycznego do omawiania zagadnień psychologicznych i medycznych, choć nie brakowało mu wiedzy zdobytej metodą konsultacji ze specjalistami w obu tych dziedzinach jak też pasji i determinacji, o tyle jezuita legitymował się solidnymi studiami, dorobkiem pisarskim oraz poparciem autorytetów naukowych zarówno w Polsce, jak w Europie Zachodniej. Abp Teodorowicz powoływał się na kilkakrotne wizyty u Teresy Neumann i obserwację z autopsji jej stanów mistycznych.

Kiedy polemika pomiędzy oponentami nabierała rozpędu, a towarzyszące jej emocje odbiegały od racjonalnych argumentów, musiał rzecz jasna wkroczyć przełożony generalny Zakonu oo. Jezuitów w obronie oskarżanego przez ormiańskiego hierarchę o liczne nadużycia o. Siwka. Tak więc wywiązała się wymiana listów pomiędzy obu hierarchami, kursująca na linii Rzym - Lwów. Zachowało się do naszych czasów 15 dokumentów, spośród których 8 napisał abp Teodorowicz, 7 - o. Włodzimierz Ledóchowski.

Zwierzchnik ormiańskokatolickiej archidiecezji lwowskiej utrzymywał dobre relacje z Zakonem oo. Jezuitów. Przyznawał, iż sięgały one czasów jego formacji intelektualno-ascetycznej w Seminarium Duchownym we Lwowie, kiedy to zetknął się z zakonnikami w Stanisławowie. Miał dobre kontakty z wybitnymi reprezentantami Zakonu w ówczesnej Galicji Wschodniej: o. Szymonem Tychowskim, o. Stanisławem Załęskim, o. Henrykiem Jackowskim, o. Janem Badenim, o. Stefanem Bratkowskim, o. Włodzimierzem Ledóchowskim. Co więcej, niedługo po święceniach kapłańskich nosił się z myślą wstąpienia w szeregi zakonników; do tego kroku miały go przygotować rekolekcje odbyte w domu jezuickim w Starej Wsi. Plany te nie doszły jednak do skutku, ale pozostały więzi przyjaźni, pogłębione później współpracą z redakcją „Przeglądu Powszechnego” 
i licznymi zakonnikami ${ }^{1}$. Znajomość zaś z o. Ledóchowskim datowała się z czasów jego pracy w redakcji wspomnianego periodyku w latach 1896-1900, a potem urzędu prowincjała 1902-1906; w tym czasie ormiański duchowny był już głową Kościoła ormiańskokatolickiego na ziemiach polskich, stąd kontakty między nimi nabrały nowej formy ${ }^{2}$.

Gros publikowanych niżej listów bezpośrednio dotyczy polemiki między armiańskim hierarchą a jezuickim uczonym. Rola o. Ledóchowskiego polegała zasadniczo na funkcji arbitra, usiłującego sine ira et studio studzić emocje abp. Teodorowicza, a zarazem bronić, choć nie bezkrytycznie stanowiska o. Siwka. Negował więc oskarżenia ormiańskiego hierarchy, jakoby jego adwersarz przypisywał mu bezkrytyczną łatwowierność w opisie zjawisk w Konnersreuth. Potwierdzał prawo zaatakowanego autora do obrony wyników swoich badań naukowych. Dezawuował insynuacje o rzekomej kampanii jezuickiej przeciw biskupom (Teodorowiczowi i Franciszkowi Lisowskiemu). Dementował winę o. Siwka za wyrządzoną obrazę pasterzowi lwowskiemu, jak również odrzucał pomównienie o nieprawowierność, ponadto oddalał jako nieprawdziwe zarzuty pychy, złej wiary i kłamstwa przypisywane zakonnemu współbratu. Nie wahał się wytknąć swemu korespondentowi niedopuszczalne $\mathrm{w}$ polemice naukowej formy sarkazmu, ironii czy złośliwości. Natomiast abp Teodorowicz przypisywał o. Siwkowi „rażące błędy z teologii mistycznej", przecenianie pierwiastka naturalnego w ocenie zjawisk religijnych, pychę i kłamstwo, a nade wszystko ubolewał nad podjęciem przez zakonnika walki z biskupa$\mathrm{mi}$, co miało siać publiczne zgorszenie.

Prezentowane listy przynoszą interesujące informacje na temat sporu naukowego pomiędzy prominentnymi przedstawicielami Kościoła polskiego, przy zachowaniu norm kultury i wzajemnego szacunku. Materiały te przechowywane są w Archiwum Fundacji Kultury i Dziedzictwa Ormian Polskich w Warszawie oraz w Archivum Romanum Societatis Iesu w Rzymie.

\footnotetext{
${ }^{1}$ Zob. w niniejszej części dokument 15.

2 Zob. w niniejszej części dokument 3.
} 


\section{Dokument 1}

Oryg.: ARSIR, bsygn., List abp. Józefa Teodorowicza do o. Włodzimierza Ledóchowskiego SJ, Lwów 23 VI 1914 r.

$\dagger$

Czcigodny $^{\mathrm{a}}$ Ojcze!

Był u mnie Ks. Kobyłecki z prośbą, bym go przyjął do mej diecezji. Mówił mi też na moją uwagę o powrocie do klasztoru, że tego już by sobie nie życzyli nawet jego przełożeni zakonni. Oczywiście zależy mu tylko na uzyskaniu samego przyjęcia, gdyż nawet wcale nie pracowałby u mnie. Otóż, co do mnie, byłbym gotów zgodzić się na to, ale pod warunkiem, że to odpowiadałoby życzeniom i interesom Zakonu. Z tego powodu odnoszę się do Ojca z prośbą, by raczył mi szczerze i jasno napisać, czy sobie tego życzy, a jeśli tak, to jeszcze prosiłbym o zniesienie się z prowincjałem. Do tutejszych Ojców boję się wprost zwracać, bo się już poparzyłem na niejasnym sformułowaniu rzeczy z ich strony z okazji Ks. Wróblewskiego ${ }^{4}$.

U nas bardzo niepewne czasy. Biskup tarnowski ${ }^{5}$ wlazł w politykę z całą właściwą mu bezwględnością. Nie wiem co z tego będzie, w każdym razie pchnął piastowców w objęcia Stapińskiego ${ }^{6}$.

Czy katolicka organizacja zdoła złamać radykalizm sprzęgnięty z żydostwem i masonerią - to się pokaże. W ogóle w ciężkich żyjemy czasach.

Polecam się modlitwom Ojca i łączę wyrazy szczerze oddane czci i braterskiego szacunku

Lwów, d[nia] 23/VI [1]914

† Teodorowicz

a Tekst pisany czarnym atramentem na trzech stronicach papieru formatu zeszytowego. W lewym górnym rogu karty tytułowej nota ołówkiem: „Pol. Mai. 1025 bis - V - 60”, w lewym górnym rogu nota inną ręką; „1914”.

${ }^{3}$ Kobyłecki Stanisław (1864-1939), święcenia kapłańskie w Zakonie oo. Jezuitów w 1894 r., 1894-1899 wykładowca matematyki w Zakładzie Naukowo-Wychowawczym w Chyrowie, 1901-1902 redaktor „Przeglądu Powszechnego", 1902-1909 studia specjalistyczne z psychologii w Europie Zachodniej u wieńczone w 1905 r. doktoratem, 1909-1912 nauczyciel matematyki, fizyki i psychologii w Chyrowie, w 1912 r. opuścił Zakon oo. Jezuitów, 1912-1918 pracownik naukowy w USA, 1918-1929 prof. filozofii na Wydziale Teologii Katolickiej Uniwersytetu Warszawskiego, 1929-1939 emeryt, w roku akad. 1925/26 dziekan fakultetu; autor prac naukowych z dziedziny psychologii, teorii poznania i logiki matematycznej. Kobytecki Stanisław, w: EWJ, oprac. L. Grzebień, Kraków 1996, s. 287-288.

${ }^{4}$ Wróblewski Alfred (1861-1943), święcenia kapłańskie w Zakonie oo. Jezuitów w 1892 r., 1886-1889 wykładowca j. polskiego i francuskiego w Zakładzie Naukowo-Wychowawczym w Chyrowie, 1894-1896, 1897-1900 i 1902-1908 przebywał we Lwowie m.in. jako redaktor pisma dla robotników „Jedność", 18961897 i 1900-1901 pracował w Krakowie, 1901-1902 przebywał w Nowym Sączu, w 1908 r. opuścił Zakon oo. Jezuitów, 1910-1924 duszpasterz w USA, 1925-1943 analogicznie w Rzymie. Wróblewski Alfred, w: EWJ, s. 764.

${ }^{5}$ Aluzja do osoby biskupa tarnowskiego Leona Wałęgi (1859-1933), pełniącego tę funkcję w latach 1901-1932.

${ }^{6}$ Zob. w niniejszej publikacji: J. Wołczański, Listy abp. Józefa Teodorowicza do abp. Józefa Bilczewskiego, dokument 89. 


\section{Dokument 2}

Oryg.: ARSIR, bsygn., List abp. Józefa Teodorowicza do o. Włodzimierza Ledóchowskiego SJ, Warszawa 5 VII 1920 r.

$\dagger$

Czcigodny ${ }^{a}$ Przezacny Ojcze Generale!

Z okazji stulecia ponownego wprowadzenia Ojców do Polski , ślę na ręce Ojca Generała najserdeczniejsze życzenia. Oby praca Ojców nowym się stała zaczynem w Polsce wskrzeszonej. Wiem dobrze, jak to Ojciec Generał kraj nasz i ojczyznę w sercu swym nosi, i wiem, jaką troską prowincję polską otacza, więc mimo woli łączy się u mnie i splata jubileuszowa pamięć z Osobą Ojca Generała.

Niestety, w Polsce przechodzimy bardzo ciężkie chwile, a jeszcze cięższe nas czekają. Masoneria połączona z socjalizmem i żydostwem pracują nad zatruciem ducha narodu, bolszewizm zaś chce okuć w kajdany ciało ojczyzny. Bóg sam bezpardonowo wejść musi w grę wypadków, by nas uratować.

Polecam się pamięci i sercu Ojca Generała, zawsze oddany z czcią głęboką

† Teodorowicz

Warszawa, d[nia] 5/VII [1]920

\section{Dokument 3}

Oryg.: ARSIR, bsygn., List abp. Józefa Teodorowicza do o. Włodzimierza Ledóchowskiego SJ, Lwów $20 \mathrm{X} 1920 \mathrm{r}$.

$\dagger$

Czcigodny ${ }^{\mathrm{a}}$, Drogi Ojcze Generale!

Szczególnej ucieszył mnie list Ojca Generała. Tyle to wspomnień odległych już dzisiaj we mnie się zbudziło! Jeżeli pamiętam Ojca Generała, jako alumna Kolegium germańskiego i wtedy już, choć się nie stykałem z Ojcem Generałem, postać Jego głęboko mi utkwiła. A później jak żywo pamiętam te głębokie prace w „Przeglądzie Powszechnym”, w którym i ja wówczas debiutowałem. A później znowu sprawa „Ruchu Kat[olickiego]”, później jeszcze prowincjalstwo Ojca Generała. W tym suchym wyliczeniu dat ileż tkwi

a Tekst pisany czarnym atramentem na jednej stronicy papieru formatu A4. W lewym górnym rogu karty tytułowej nota ołówkiem ręką archiwisty: „Pol. Mai. 1025 bis - V - 61”, niżej nota czarnym atramentem inną ręką: „R. 11/X 20” i nieczytelne trzy wyrazy. W prawym górnym rogu nota ołówkiem: „1920”.

7 OO. Jezuici wypędzeni w 1820 r. z Rosji osiedlili się m.in. na terenie monarchii austro-węgierskiej w Galicji, podejmując funkcje duszpasterskie, animację ruchu chrześcijańsko-społecznego oraz organizację szkolnictwa katolickiego.

a Tekst pisany czarnym atramentem na dwóch stronicach papieru formatu zeszytowego. W prawym górnym rogu karty tytułowej nota ołówkiem ręką archiwisty: „Pol. Mai. 1025 bis - V - 62, 2-X27”.

8 Zob. w niniejszej publikacji: J. Wołczański, Korespondencja abp. Józefa Teodorowicza z abp. Adamem Stefanem Sapieha, dokument 94.

${ }_{9}$ Zob. w niniejszej publikacji: tenże, Listy abp. Józefa Teodorowicza do abp. Józefa Bilczewskiego, dokument 1 . 
przeżyć moich osobistych, które bynajmniej na tym się nie skończyły, gdyż wyjeżdżając parokrotnie do Rzymu zawsze zawdzięczałem rozmowom Ojca Generała tyle światła i tyle wskazań.

Zrozumie więc Ojciec Generał, jak mi są szczególniej cenne życzenia i to jeszcze poparte tak hojną dla mnie i szczodrobliwą duchową jałmużną Mszy św. Dziękuję za to z głębi serca i będzie to moim obowiązkiem kołatać do Boga, by zdrowie Ojca Generała prawdziwym cudem tak długo utrzymane Bóg jeszcze długo dla dobra Zgromadzenia i dobra naszego zachował.

Łączę najoddańsze wyrazy, sługa w Chr[ystusie]

Lwów, d[nia] 20/X [1]927

† Teodorowicz

\section{Dokument 4}

Oryg.: ARSIR, bsygn., List abp. Józefa Teodorowicza do o. Włodzimierza Ledóchowskiego SJ, Lwów $1 \mathrm{X} 1928 \mathrm{r}$.

$\dagger$

Czcigodny ${ }^{\mathrm{a}}$, Przezacny Ojcze Generale!

Niewymownie się ucieszyłem listem i przesyłką Ojca Generała, bo w takiej delikatnej pamięci na mnie pośród tylu wielkich prac i dzieł widzę dowód łaskawości dla dawnego współpracownika w „akcji kat[olickiej]”, za który ze serca dziękuję. Posługuję się tu nazwą, jaką Ojciec Generał w liście Swym użył, tylko dopełniam ją jeszcze. Bo przede wszystkim byłem uczniem w szkole mistrzów socjalnych idei, wśród których obok O. Badeniego ${ }^{10}$ był i Ojciec Generał zarówno przez swe dyrektywy, jak i zawsze tak głębokie a tak szczere artykuły. Była to doprawdy epoka przełomowa nadpoczęta encykliką Leona $13^{11}$, szkoda tylko wielka, że przez śmierć śp. O. Badeniego i ustąpienie na prowincjalstwo Ojca Generała niepodtrzymana dostatecznie w ciągu dalszym.

Dzieło mi łaskawie nadesłane o. Grandmaisona ${ }^{12}$ jest wydarzeniem wielkim w literaturze dotychczasowej katolickiej dotyczącej życia Jezusowego ${ }^{13}$. Bo jakkolwiek nie jest to życie Chrystusowe w znaczeniu zwyczajnym, to jednak dzieło to wzbija się na wyżyny

a Tekst pisany czarnym atramentem na trzech stronicach papieru formatu zeszytowego. W lewym górnym rogu nota ołówkiem ręką archiwisty: „Pol. Mai. 1025 bis - V - 63”, w prawym górnym rogu nota inną ręką: „1928”.

${ }^{10}$ Badeni Jan (1858-1899), święcenia kapłańskie w 1885 r. w Zakonie oo. Jezuitów, 1884-1897 publikował swe prace w „Przeglądzie Powszechnym”, 1896-1897 superior domu we Lwowie, 1897-1899 prowincjał Prowincji Galicyjskiej, aktywny działacz katolicko-społeczny, promotor prasy katolickiej. Badeni Jan, w: EWJ, s. 23-24.

11 Właściwie: Leon XIII.

12 Grandmaison Lèonce de (1868-1927), święcenia kapłańskie w 1899 r. w Zakonie oo. Jezuitów, 19081919 redaktor miesięcznika „Etudes”, założyciel w 1910 r. dwumiesięcznika „Recherches de science religieuse”, 1899-1901 wykładowca t. fundamentalnej w Seminariach Duchownych w Lyonie, Canterbury i Ore Place, autor dzieł teologicznych. B. Natoński, Grandmaison Lèonce de, w: EK, t. 6, red. zbior., Lublin 1993, kol. 43-44.

${ }^{13}$ L. de Grandmaison, Jésus-Christ. Sa personne, son message, ses preuves, t. 1-2, Paris 1928. 
naukowe takie, z jakimi nie może wejść w żadne porównanie żadna z dotychczasowych biografii Jezusa. Oczywiście z doskonałości dzieła płyną i jego usterki, i właśnie piszę o tym do jednego z Ojców, ale usterki nie przesłaniają znaczenia samego dzieła. Już skorzystałem praktycznie z ustępu dzieła o kwestii synoptycznej dla księdza biskupa Lisowskiego $^{14}$, który od 5 lat miał na biurku manuskrypt tłumaczenia listów św. Pawła ${ }^{15}$ w strofach i nie miał odwagi ich wydać. Dopiero postawienie jasne tej kwestii u Grandmaisona skłania go do wydania tej pracy.

Wracam z konferencji biskupiej w Gnieźnie, która zgromadziła aż 37 biskupów! 3 było nieobecnych, więc episkopat dosięga już 40. Ta ilość biskupów siedzących w dużej Sali zaimponowała nuncjuszowi ${ }^{16}$, który czegoś podobnego jeszcze nie widział. Zjazd poprzedziły pierwsze wspólne rekolekcje episkopatu dawane przez 84-letniego, trzęsącego się i pogiętego Ojca Bernarda ${ }^{17}$. Konferencje zachwyciły wszystkich, bo i rekolekcje urobiły, i nastroiły serca modlących, i po raz pierwszy referaty biskupów były naprzód opracowane, a nie improwizowane jak dotąd w ostatniej dopiero chwili.

Jeszcze raz dziękując Ojcu Generałowi za pamięć i serce, łączę zawsze bardzo oddane wyrazy głębokiej czci

Lwów, d[nia] 1/X 1928

† Teodorowicz

\section{Dokument 5}

Oryg.: AFKDOPW, teczka 141: Spuścizna abp. Józefa Teodorowicza, sygn. 945/420 (8) [7], List o. Włodzimierza Ledóchowskiego SJ do abp. Józefa Teodorowicza, Rzym 25 I 1932 r.

Rzym, dnia 25 stycznia 1932

Ekscelencjo $^{a}$, Najprzewielebniejszy Księże Arcybiskupie!

Niestety, teraz dopiero dowiedziałem się o korespondencji O. Siwka ${ }^{18}$ z Waszą Ekscelencją w sprawie Teresy Neumann ${ }^{19}$. Ponieważ Wasza Ekscelencja w liście Swym z dnia 11 stycznia ${ }^{20}$ i o mnie wspomina, dlatego pozwalam sobie sam w tej sprawie zwrócić się do Waszej Ekscelencji.

${ }^{14}$ Zob. w niniejszej publikacji: J. Wołczański, Korespondencja abp. Józefa Teodorowicza z abp. Adamem Stefanem Sapieha, dokument 77.

${ }^{15}$ Św. Paweł z Tarsu (ok. 5-10 - ok. 64-67), nawrócony na chrześcijaństwo Żyd, „Apostoł Narodów”, autor 13 listów apostolskich należących do kanonu Nowego Testamentu.

${ }^{16}$ W 1. 1928-1936 funkcję nuncjusza apostolskiego w Polsce pełnił abp Francesco Marmaggi (1870-1949).

17 Zob. w niniejszej publikacji: J. Wołczański, Korespondencja abp. Józefa Teodorowicza z abp. Adamem Stefanem Sapieha, dokument 83.

a Tekst pisany na maszynie $\mathrm{z}$ wyjątkiem autografu autora listu na 1,5 stronicy papieru formatu A4. W prawym górnym rogu karty tytułowej nota ołówkiem ręką archiwisty: „945/420(8) [7]”.

${ }_{18}$ Zob. w niniejszej publikacji: J. Wołczański, Korespondencja abp. Józefa Teodorowicza z abp. Adamem Stefanem Sapieha, dokument 101.

19 Tamże, dokument 91.

${ }^{20}$ Zob. w niniejszej publikacji: J. Wołczański, Korespondencja abp. Józefa Teodorowicza z różnymi osobami w sprawie Teresy Neumann, dokument 24. 
Przede wszystkim zaznaczyć pragnę, a co O. Siwkowi już oświadczyłem, że wcale nie życzę sobie, ażeby na recenzję Waszej Ekscelencji dał odpowiedź; byłoby to bowiem, jak uważam, z różnych powodów nieodpowiednie, a może i szkodliwe. Mam również nadzieję, że i Wasza Ekscelencja nie będzie się czuł obowiązany wytknąć O. Siwkowi w publicznej ocenie błędy rzucające podejrzenie na jego prawowierność. Bo zdaje mi się po przeczytaniu książki, że nie ma do tego powodów, choć rozumie się, jak to zawsze bywa, można być odmiennego zdania lub też życzyć sobie tu i ówdzie ściślejszego wyrażenia. Wasza Ekscelencja rozumie to dobrze, że zgoła co innego jest w prywatnej korespondencji wyrażać Swe wrażenia o jakiejś infiltracji racjonalizmu, aniżeli wysuwać tego rodzaju zarzuty w otwartej recenzji. W tym ostatnim wypadku byłbym zmuszony dać O. Siwkowi pozwolenie na otwartą odpowiedź.

Niech mi tu także nadmienić będzie wolno, że w naszych czasach na całej kuli ziemskiej oprócz racjonalizmu zagraża także prawdziwej pobożności i fala niezdrowego mistycyzmu, który w pewnych okolicach już smutne wydaje owoce.

Nareszcie pozwolę sobie wspomnieć, co Waszej Ekscelencji może nie jest znanym, że najwidoczniej istnieje teraz międzynarodowe sprzysiężenie przeciwko naszemu zakonowi, jak to przedwczoraj właśnie także Opat-Prymas Benedyktynów zauważył, sprzysiężenie, które rozporządza ogromnymi zasobami i oprócz kłamstw i oszczerstw od wieków powtarzanych ze wszystkiego korzysta, ażeby w opinii katolików i niekatolików Towarzystwu zaszkodzić. Stąd też musimy zebrać wszystkie siły, ażeby odeprzeć niebezpieczne ataki. W tej sytuacji jestem zupełny pewny, że recenzję Biskupa, która by zarzucała jednemu z naszych Ojców racjonalizm lub modernizm w lot by wyzyskano przeciwko zakonowi.

Jak mi żal naprawdę, że nie ma jeszcze dogodnej komunikacji powietrznej ze Lwowem (spodziewam się jednak, że i to wkrótce nastąpi), a nie omieszkałbym w kilku godzinach przewieźć się do Lwowa, gdzie niezawodnie Wasza Ekscelencja raczyłby mi pozwolić na dłuższą rozmowę, w której by niejedno nieporozumienie wyrównane być mogło.

Całując ze czcią najgłębszą pierścień Waszej Ekscelencji, z pokorą proszę o Arcypasterskie błogosławieństwo, stary sługa w Chrystusie

Wł[odzimierz] Ledóchowski SJ ${ }^{\text {b21 }}$

Jego Ekscelencja

Najprzewielebniejszy Ksiądz Arcybiskup

Ksiądz Józef Teodorowicz

Lwów

b Autograf czarnym atramentem.

${ }^{21}$ Zob. w niniejszej publikacji: J. Wołczański, Listy abp. Józefa Teodorowicza do abp. Józefa Bilczewskiego, dokument 59 . 


\section{Dokument 6}

Koncept: AFKDOPW, teczka 133: Spuścizna abp. Józefa Teodorowicza, sygn. 1605/184 [7], List abp. Józefa Teodorowicza do o. Włodzimierza Ledóchowskiego SJ, [Lwów] 13 II 1932 r.

13/II [1]932

W[ielce] ${ }^{a}$ Czcigodny, Przezacny O. G[enerale],

Otrzymałem właśnie list O. Generała przysłany mi tu do Krynicy ze Lwowa. Prawdziwie jestem wzruszony, gdy pomyślę, że O. Generał wśród tylu zajęć, trosk znalazł jeszcze czas na pisanie do mnie, lecz równocześnie zmartwił mnie list O. Generała. Albowiem jak widzę stałem [się] choć mimowoli przyczyną przykrości dla Ojca Generała i to w chwili i czasie tylu trosk i niepokojów.

Otrzymałem list w chwili, gdy część mej pracy „Zjawiska mistyczne i ich tłumaczenia” ukazała się już w „Ateneum”22, zaś cały manuskrypt jest złożony w redakcji. Napisałem jednak niezwłocznie do redakcji, że zmieniam zakończenie i tekst zmieniony prześlę. W przerobionym zakończeniu pomieszczę $\mathrm{w}$ formie pośredniej czy też bezpośredniej oświadczenie, które ponad wszelką wątpliwość stwierdza, że krytyka moja w niczym nie zmienia głębokiego mojego przeświadczenia o prawowierności O. Siwka. Jakkolwiek nie ma dla mnie wątpliwości o silnym uzależnieniu się O. Siwka od Ewalda ${ }^{23} \mathrm{i}$ innych, to jednak oświadczenie to moje odpowie najgłębszemu przekonaniu, że dzieje się to zawsze w granicach, w których zupełnie jego głęboka i żywa wiara złączona z osobistą pobożnością nie jest naruszona. Oceniam też punkt O. Siwka, który chciał przeciwdziałać zbytniej łatwowierności w sprawie Konnersreuth, ale szczerze ubolewam nad tym, już choćby ze względu na niego samego, że się do tego problemu trudnego i skomplikowanego zabrał $\mathrm{z}$ tak małym przygotowaniem. $Z$ tego powodu, przynajmniej ja tak sądzę, raczej zaszkodził sprawie jak pomógł. Bo nad wyraz wszelki słuszne jest spostrzeżenie Ojca Generała o fali niebezpiecznej idącej dziś na świat fałszywego mistycyzmu. I z pewnością zbytnia łatwowierność w ocenie zjawisk mistycznych może torować drogi dla tego niebezpiecznego powodu, z drugiej jednak strony fałszywemu mistycyzmowi jedynie skutecznie przeciwdziałać zdoła należyte oświetlenie prawdziwego mistycyzmu. Niestety, w książce O. Siwka znajdują się rażące błędy z teologii mistycznej, kryteria zaś mistyczne są tam, gdzie jedynie nie tylko nie rozwiązują problemu, [ale są] zupełnie pominięte i zastąpione psychologią wyolbrzymioną kosztem pierwiastka mistycznego. Do tego się przyłącza fakt wysoce kompromitujący dla każdego badacza, iż O. Siwek w najpoważniejszych kwestiach przedstawił zupełnie fałszywie stan faktyczny zjawisk, których zbadaniem się właśnie $[. . .]^{\mathrm{b}}$. To właśnie był wzgląd, który mi kazał przemóc wszelkie inne względy i wystąpić przeciw tej pierwszej w Polsce próbie na tym polu, wedle jednak mego widzenia rzeczy tak niefortunnie przeprowadzonej.

a Tekst pisany czarnym atramentem na dziewięciu stronicach papieru formatu A4. Brak miejsca wystawienia dokumentu i autografu autora.

${ }^{22}$ J. Teodorowicz, Zjawiska mistyczne i ich ttumaczenia, AK, 18(1932), t. 29, z. 1, s. 1-16; z. 2, s. 105-121; z. 3, s. 209-229; z. 4, s. 313-338.

${ }^{23}$ Zob. w niniejszej publikacji: J. Wołczański, Korespondencja abp. Józefa Teodorowicza z prof. Stefanem Dąbrowskim, dokument 29.

b Brak ciągu dalszego tekstu. 
Poza tym kierowały tu mną i inne jeszcze względy. Oto uwikłałem się w sprawę Konnersreuth pod wpływem Ks. Biskupa Lisowskiego, który mnie najpierw tam pociągnął, a potem narzucił mi nie ledwo wykład publiczny o Konnersreuth we Lwowie, powtórzony później przeze mnie w Krakowie, a naówczas już inne czynniki wpłynęły na to, że przygotowuję opracowanie tego problemu w osobnej książce po niemiecku ${ }^{24}$.

Po tym wszystkim prawie, że nie ulega dla mnie wątpliwości, iż właśnie tą rzekomą łatwowiernością moją O. Siwek usprawiedliwiał potrzebę napisania mej książki. Bo przecież w Krakowie pod koniec przeszłego roku, gdy mu o tej kwestii mówiłem, nic o tym nie wspominał, że myśli pisać o Konnersreuth, a więc chyba jeszcze nie miał tego zamiaru, a gdy mu w liście moje przypuszczenie wyraziłem, pominął tę kwestię w odpowiedzi zupełnym, a więc wymownym milczeniem. W takich warunkach postawiony poniekąd w stan oskarżenia i to w kwestii bardzo ważnej dla mnie jako biskupa, mam obowiązek się bronić. Ten obowiązek jest tym poważniejszy, że tu nie idzie o osobistą obronę, ale obronę samego kierunku o życiu nadprzyrodzonym. Muszę przy tym i to nadmienić, że na ten występ mój O. Siwek był przygotowany. Kiedy bowiem w roku zeszłym w lutym pojawiły się pierwsze artykuły O. Siwka w „Przeglądzie Powszechnym”, skorzystał Ksiądz Biskup Lisowski z pobytu ówczesnego prowincjała we Lwowie i przedstawił mu, jak smutne to następstwa wywoła [w] opinii [społeczeństwa], które [z]obaczy biskupów (biskup Lisowski zaangażował się i to pierwszy przez występ publiczny) i jezuitów w dwu przeciwnych i zwalczających się obozach. Dawał też do poznania przez to samo, że biskupi milczeć nie będą i będą przymuszeni stanowiska swojego publicznie bronić. Nie twierdzę, by stanowisko Ks. Biskupa musiało być w tym wypadku całkiem słuszne, ale to pewne, że o takim zagrożeniu O. Siwek winien był być przygotowanym wydając swoją książkę na zapowiedziane konsekwencje. W takich warunkach rzucił on nam względnie mnie zupełnie świadomie wyzwanie, ja zaś byłem tylko tym, który wezwanie jego zmuszony był przyjąć i przyjąłem je istotnie. Istotny mój cel odpowiedzi nie jest osobisty, ale podyktowany następstwami ogólnej natury, a poza tym głoszenia odczytów i pisania książki. Do tego się przymieszała jednak jeszcze i sprawa osobista.

Każdy zrozumie, [że] trudno by mi było przenieść na sobie, by zarzut niekrytycznej łatwowierności do mnie przylgnął. Oczywiście nie mam żadnej pretensji do nieomylności w tej kwestii. Mogę się mylić, a ktoś, kto jest przeciwnego zdania może mieć słuszność. Ale i w takim wypadku jeszcze jestem [z]obowiązany do tego, ażeby chociażby moja krytyka wspierała się jednak na poważnym badaniu, a nie była li tylko następstwem lekkomyślnej, a u biskupa wprost ubolewania godnej i pod pewnym względem gorszącej łatwowierności. Otóż z tego tytułu nie wolno mi jest pominąć milczeniem książki, która tak głęboko w cały ten problem wchodzi i muszę się z nią, chcę czy nie chcę, rozprawić.

Do tych zasadniczych względów przyłącza się jeszcze wzgląd osobisty, jeśli go osobistym nazwać mogę. Książka O. Siwka jest poniekąd oskarżeniem i to moralnym mojego stanowiska, jak i stanowiska Ks. Biskupa Lisowskiego (i on miał publiczny odczyt) o bezkrytyczną łatwowierność narzucaną jeszcze innym. W pracach łączących się ze

${ }^{24}$ J. Teodorowicz, Konnersreuth im Lichte der Mystik und Psychologie, Salzburg-Leipzig 1936. 
zjawiskami nadprzyrodzonymi podobna łatwowierność u biskupa jest jednak poważnym oskarżeniem. Czy o tym myślał O. Siwek czy nie, w to ja nie wchodzę, a z różnych okoliczności wnoszę, że jednak tak istotnie było, że moje odczyty dały mu asumpt do napisania książki przeciwstawiającej się mojemu stanowisku. Nawet w jednym miejscu znajduję wyraźną, choć bezimienną, ale dla słuchaczy krakowskich przejrzystą aluzję do mej naiwnej łatwowierności (s. 239, nawiasem dodam, że fakt przeze mnie opowiedziany O. Siwek nieściśle przedstawił).

Ten zupełnie wyjątkowy stan rzeczy, że dyskusja czysto naukowa w tym wypadku zahaczała o stronę moralną, przewidywał Ks. Biskup Lisowski, który zaraz po pierwszych artykułach O. Siwka w „Przeglądzie” ostrzegł ówczesnego prowincjała, jak fatalne to wywoła wrażenie, że OO. Jezuici dając odpowiedź na zajęte przez 2 biskupów stanowisko wywołują wrażenie jakiejś kampanii chociażby na naukowym polu prowadzonej przeciw tym biskupom. Dał też do poznania O. Prowincjałowi, że biskupi nie ustąpią.

Mógł oczywiście O. Siwek ostrzeżenie biskupa zignorować, ale w takim razie nic a nic nie mógł się temu dziwić, że nastąpiło to, co Ks. Biskup ostrzegając zapowiedział, tj. iż jeden z zaatakowanych biskupów da odpowiedź. Nie można mieć o to żadnej pretensji do O. Siwka, że napisał dzieło naukowe nie oglądając się na żadne względy, bo mu to zawsze wolno, ale konsekwencje swojego kroku musiał w takim razie przyjąć. Książka bowiem jego po tym ostrzeżeniu była wezwaniem, które tamta strona, to jest my, względnie ja, przyjąć musiałem. Nie przypisuję sobie bynajmniej nieomylności co do mego stanowiska, może nawet być ono błędne, ale bądź co bądź okupione jest ono wielu wysiłkami, wielokrotną bytnością w Konnersreuth, gruntownym studium zjawisk, tak samo studium mistyki i psychologii. Jeśli więc bym się nawet mylił, to omyłka moja nie płynęła jednak z naiwnej i bezkrytycznej łatwowierności. Nie o Teresę Neumann tu idzie; co do niej to może każdy zajmować stanowisko pro albo contra, ale o to tu szło, by w zajętym stanowisku uzasadnić, że pro nie jest owocem bezkrytycznej łatwowierności, sympatii lub uprzedzeń, ale poważnych naukowych studiów. A więc jednym słowem, zarówno ze względów ogólnej natury, jak ze względu na to, że w tej sprawie zabrałem głos publicznie, jak ze względu na książkę, którą przygotowuję, a w końcu ze względów osobistych musiał[em] w tej sprawie zabrać głos i dać odpowiedź O. Siwkowi, na którą został on z dawna w ostrzeżeniu Ks. Biskupa Lisowskiego przygotowany.

Przedstawiłem Ojcu Generałowi z całą szczerością przebieg całej sprawy, ubolewając ogromnie, co powtarzam raz jeszcze nad tym, że sprawiam przez to wszystko kłopotliwą przykrość. Niech mi O. Generał wierzy, że w tak ciężkich obecnych przejściach dla Ojca Generała nieraz się przenoszę myślą na plac Borgo di S. Spirito i [... $]^{c} \mathrm{w}$ to i zastanawiam [się] nad tym, ileż to cierpieć dziś musi O. Generał. Modlę się też gorąco, by Bóg krzepił O. Generała duchowo, a umacniał fizycznie. Na wzmiankę o [...] połykam tylko ślinkę, bo i jakże bym rad z Ojcem Generałem odbyć chociażby jedną z tych rozmów, która każda tyle zostawiała w mej duszy i wspomnień, i światła. Może mi Bóg da kiedy przybyć do Rzymu, bo niestety liczę tylko na [... $]^{\mathrm{e}}$ eskapady prymasa, a już mniej Ojca Generała.

\footnotetext{
c Wyraz nieczytelny.

d Wyraz nieczytelny.

e Wyraz nieczytelny.
} 
Proszę przyjąć przy tej sposobności najgorętsze wyrazy współczucia z powodu strasznych prześladowań szatana, który uderza na przednią straż Kościoła po to, by dosięgnąć potem sam Kościół.

Z wyrazami czci najgłębszej, a zawsze bardzo a bardzo oddanej.

\section{Dokument 7}

Kopia: AFKDOPW, teczka 136: Spuścizna abp. Józefa Teodorowicza, sygn. 1189/420 (12) [7], List abp. Józefa Teodorowicza do o. Włodzimierza Ledóchowskiego SJ, Lwów 22 IV 1932 r.

Najczcigodniejszy ${ }^{\mathrm{a}}$ Ojcze Generale!

Spotkała mnie ogromna przykrość ze strony redakcji „Ateneum”25. Zaraz po liście wysłanym do Ojca Generała napisałem do redakcji, ażeby zakończenie moje skreślili i czekali na przesłanie innego zakończenia. Tymczasem redakcja nie powiadomiwszy mnie, że w kwietniowym numerze „Ateneum” myśli zakończyć moją rozprawę, nie czekając na wysłanie zakończenia umieściła pomimo bardzo wyraźnego mego oświadczenia to właśnie zakończenie dawne. Wprawdzie nie ma w numerze żadnego nowego zarzutu i wprawdzie kilkakrotne moje poprzednie oświadczenia ponad wszelką wątpliwość wyraziły moje przekonania o prawowierności O. Siwka, to jednak fakt, który się wydarzył jest mi osobiście przykry ze względu na list, który pisałem do Ojca generała. Słyszałem, że O. Siwek nosi się z myślą odpowiedzenia mi; otóż oświadczam Ojcu generałowi, że z mej strony nic nie mogę mieć przeciw temu.

Przy tej sposobności łączę dla Ojca Generała najgłębsze wyrazy czci.

Lwów, dnia 22 kwietnia 1932

\section{Dokument 8}

Oryg.: AFKDOPW, teczka 141: Spuścizna abp. Józefa Teodorowicza, sygn. 944/420 (8) [7], List o. Włodzimierza Ledóchowskiego SJ do abp. Józefa Teodorowicza, Rzym 2 V 1932 r.

Rzym, 2 maja 1932

Ekscelencjo $^{a}$, Najprzewielebniejszy Księże Arcybiskupie!

W tej chwili otrzymuję tak łaskawy list waszej Ekscelencji z 27 kwietniab i spieszę się, by za ten list, jako też za poprzedni najserdeczniej podziękować. Polemika jednego z naszych Ojców z Księciem Kościoła jest mi ogromnie przykrą, ale w danych warunkach muszę pozwolić na odpowiedź. Gorąco modlić się będę, by wszystko wyszło na chwałę Bożą.

Całując z głęboką czcią ręce Waszej Ekscelencji, zawsze oddany sługa

Wł[odzimierz] Ledóchowski SJ

a Tekst pisany na maszynie na jednej stronicy papieru formatu A4. Brak autografu autora.

25 Właściwie: „Ateneum Kapłańskiego”.

a Tekst pisany czarnym atramentem na jednej stronicy papieru formatu A4. W prawym górnym rogu karty nota ręka archiwisty: „944/420(80 [7]”.

b Brak owego dokumentu. 


\section{Dokument 9}

Oryg.: AFKDOPW, teczka 141: Spuścizna abp. Józefa Teodorowicza, sygn. 943/420 (8) [7], List o. Włodzimierza Ledóchowskiego SJ do abp. Józefa Teodorowicza, Rzym 16 II 1934 r.

Ekscelencjo ${ }^{a}$, Najprzewielebniejszy Księże Arcybiskupie!

Rzym, dnia 16 lutego 1934

Niedawno temu otrzymałem od O. Prowincjała kopię listu Waszej Ekscelencji ze stycznia bez bliższej daty, w którym Wasza Ekscelencja pisze, że nie chodzi Mu zupełnie o stronę doktrynalną, ale przede wszystkim i głównie o stronę moralną, która w książce O. Siwka wybija się na pierwszy plan. Ta strona moralna to wina na mnie złożona, że ja manuskrypt O. Siwka przeczytałem, że z rozporządzenia co do Konnersreuth jakie wysłałem do Prowincji zrobiłem wyjątek jedynie dla O. Siwka i jemu dałem osobne pozwolenie, by się podjąć walki z Księżmi Biskupami. Możliwe, że Wasza Ekscelencja, do którego jak widzę rozmaite wieści dochodzą, przez powiedzenia innych, a nawet przez jedno lub drugie powiedzenie w liście niezupełnie jasne O. Siwka był w błąd wprowadzony. Z mojej jednak strony mogę Waszej Ekscelencji stanowczo oświadczyć, że ja nigdy manuskryptu O. Siwka nie przeczytałem; nie dawałem także O. Siwkowi żadnego wyjątkowego pozwolenia na pisanie o Konnersreuth, ani też rozkazu na drukowanie jego książki. W kwestiach pisarstwa, nawet kiedy ktoś zgłasza się do mnie z jakąś pracą i cenzorzy rzymscy są za jej drukowaniem, przyjęta jest u nas zasada, że wtedy Prowincjałowi daję pozwolenie i jemu całą rzecz zostawiam. Jak długo jestem generałem, stale trzymam się tej zasady i nie robiłem żadnego wyjątku.

O jakiejś walce z Księżmi Biskupami zupełnie nic nie wiedziałem, ani też nigdy nie myślałem. Przez całe życie moje starałem się zawsze odnosić do Księży Biskupów z najgłębszą czcią i szacunkiem; ufam, że za łaską Bożą i na stare lata je zachowam i z tej drogi nie zejdę.

Mam nadzieję, że wobec tych moich oświadczeń Wasza Ekscelencja sam uzna, iż nie zasługuję na tego rodzaju ciężki zrobiony mi w liście do O. Prowincjała zarzut.

Ze czcią najgłębszą całuję pierścień Waszej Ekscelencji i z pokorą proszę o Arcypasterskie błogosławieństwo, najniższy sługa w Chrystusie

Wł[odzimierz] Ledóchowski SJ

Jego Ekscelencja

Najprzew[ielebniejszy] Ksiądz Arcybiskup

Józef Teodorowicz

Lwów

a Tekst pisany maszynowo z wyjątkiem autografu autora na dwóch stronicach papieru formatu A4. W górnej partii karty tytułowej nota ołówkiem: „943/428(8) [7]”. 


\section{Dokument 10}

Kopia: AFKDOPW, teczka 132: Spuścizna abp. Józefa Teodorowicza, sygn. 1606/185 [4], List abp. Józefa Teodorowicza do o. Włodzimierza Ledóchowskiego SJ, Lwów 26 II 1934 r.

\section{Wielce ${ }^{a}$ Czcigodny Ojcze Generale!}

Bardzo dziękuję Ojcu Generałowi za list łaskawy i tak dla mnie cenny ze względu na wyświetlenie stanowiska Ojca Generała w całej tej przykrej sprawie.

Pozwoli Ojciec Generał, że ja z mej strony dam także pewne wyświetlenie jedynie w tym celu, aby się nie zdawało Ojcu Generałowi, że ja polegam w moim twierdzeniu na jakichś niepoważnych donosach; zdaje mi się bowiem, że tego przekonania jest Ojciec Generał skoro mi pisze, iż do mnie, jak widzi, „rozmaite wieści dochodzą”.

Istotnie, dochodziły do mnie i dochodzą różne wieści, ale wybieram z nich tylko takie, które mają charakter dokumentów; nie szukam ich wcale, dochodzą one same do mnie. Tak na przykład z redakcji „Ateneum” przysłano mi listy O. Siwka o wycofanie manuskryptu wprost brutalne i ordynarne, grożące redakcji sądem, a napadające na mnie; tak z redakcji "Szkoły Chrystusowej” ${ }^{26}$ przysłano mi list O. Siwka, w którym ten mnie mieni wobec obcej redakcji wprost oszczercą. Tak na przykład przysyłają mi znowu inny list, już nie O. Siwka, ale jego agenta w Krakowie, również z ciekawymi szczegółami, zupełnie kłamliwymi, które pochodzą od O. Siwka. Jedne tylko dokumenta sam zdobyłem, tj. te, które dotyczyły ataku na mnie w Rzymie na wykładzie O. Siwka, ale i to się stało dopiero wtedy, kiedy zwrócono moją uwagę na ten wykład ze strony księży przybywających do Polski i ze strony zakonnic, którym opowiadali o tym studenci innych narodowości.

Ale przede wszystkim listy, które O. Siwek do mnie pisał są dla mnie dokumentami. Inne jeszcze źródła pomijam, a są one liczne dzięki niezwykłemu talentowi propagandy i reklamy, jaki posiada widocznie O. Siwek oddziaływując na opinię przez niektórych swoich kolegów zakonnych.

Tyle w sprawie formalnej, a teraz przystępuję do najważniejszego istotnego punktu Ojca Generała, około którego wszystko inne właśnie się obraca. Dotyczy on kwestii pozwolenia Ojca Generała na wydrukowanie książki O. Siwkowi. Jak z listu Ojca Generała widzę, to Ojciec Generał takiego pozwolenia bezpośrednio nie dawał, zdając całą sprawę w kwestii wydawnictw na decyzję prowincjałów dotyczącej prowincji.

Ponieważ muszę uzasadnić wobec O. Generała zajęte przeze mnie moje stanowisko, to podaję fakty, na jakich oparłem moje twierdzenie, iż Ojciec Generał pozwolenie takie dał. Co do pierwszej książki ${ }^{27}$ i pozwolenia jej napisania, to polegałem na całkiem wyraźnych słowach listu O. Siwka. Pisze on w liście z 17/I 1932: „Istotnie miałem od Generała formalne pozwolenie na napisanie książki". (Podkreślone przeze mnie). Zrozumie Ojciec Generał, że nie mogę już tutaj mówić o niezupełnie jasnym powiedzeniu O. Siwka; to jest twierdzenie jasne, kategoryczne.

\footnotetext{
a Tekst pisany maszynowo na 11,5 stronicach papieru formatu A4. Brak autografu autora.

${ }^{26}$ „Szkoła Chrystusowa” - dwumiesięcznik wydawany we Lwowie w 1. 1930-1939 o tematyce życia duchowego.

27 P. Siwek, Konnersreuth w świetle nauki i religii, Kraków 1931.
} 
Co do drugiej książki O. Siwka o metodach ${ }^{28}$, to pozwolę sobie tutaj zacytować list Ojca generała własnoręcznie napisany z daty 2 V 1932. Pisze w nim Ojciec Generał: „Polemika jednego z naszych Ojców z Księciem Kościoła jest mi ogromnie przykrą, ale

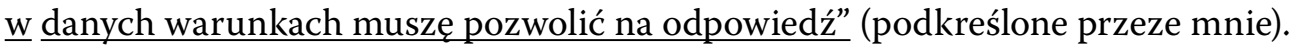

Pierwsze pozwolenie uważałem za wyjątkowe ze względu na poprzedni zakaz Ojca Generała przesłany poprzedniemu O. Prowincjałowi po ukazaniu się pierwszych artykułów O. Siwka w „Przeglądzie Powszechnym”. O tym liście Ojca Generała i o tym zakazie poinformował Ks. Biskupa Lisowskiego ówczesny Prowincjał w odpowiedzi na przedstawienie Ks. B[is]k[u]p[a] Lisowskiego uczynione Prowincjałowi o niewskazanym i niepożądanym wydaniu pracy O. Siwka dezawuującej stanowisko dwu Ks. Ks. Biskupów zajęte w ich publicznych wykładach.

Wyjątkowy charakter zezwolenia Ojca Generała na wydrukowanie drugiej książki uwidoczniony jest także w tym wszystkim, co się stało z manuskryptem O. Siwka w Krakowie. Ojcowie dali manuskrypt Ks. Biskupowi krakowskiemu do aprobaty; oczywiście w pracy O. Siwka i odpowiedzi mi danej nie było nic contra fidem i mores ${ }^{29}$, więc Ks. Biskup okazał gotowość wydania aprobaty; zwrócił jednak uwagę ks. Rostworowskiemu ${ }^{30}$ na następstwa w opinii publicznej tego rodzaju polemiki zakonnika z Biskupem. Na to O. Rostworowski odpowiedział Ks. Biskupowi, że książka O. Siwka jednak w druku się nie ukaże. Kiedy się zaś ukazała, wówczas O. Rostworowski napisał list do Ks. Biskupa krakowskiego z usprawiedliwieniem, że przyszedł z Rzymu nakaz wydania tej książki.

Było to więc tylko nowe potwierdzenie, że nie O. Prowincjał wówczas w Krakowie nieobecny, odbywający podróż po Wegrzech, nie Ojcowie krakowscy, ale Rzym rozstrzygnął tę kwestię na rzecz O. Siwka i drukowania tej jego odpowiedzi tak niestety fatalnej i tak kompromitującej swoją stronę moralną. Ten fakt występuje tym jaskrawiej, o ile istotnie manuskrypt był przedtem w Krakowie w ręku recenzentów krakowskich, ale rozstrzygniecie samo - a o to głównie chodziło - zostało ostatecznie zadecydowane nie przez nich, ale przez Rzym. Otóż po tym wszystkim nie mogłem mieć wobec tego żadnej wątpliwości co do tego, kto tę rzecz rozstrzygnął i kto dał w tych warunkach ostateczny nakaz drukowania.

Przychodzę teraz do drugiego punktu, w którym Ojciec Generał mi pisze: „O jakiejś walce z Ks. Ks. Biskupami zupełnie nic nie wiedziałem, ani też nie myślałem”. Otóż przykro mi niesłychanie, że w tym duchu Ojciec Generał zrozumiał znaczenie odnośnych ustępów mojego listu do Ojca Prowincjała. Mnie przecież nigdy przez myśl nie przeszło choćby podejrzenie Ojca Generała o jakąś walkę z Ks. Ks. Biskupami. Ojciec Generał zbyt wysoko stoi, ażeby Go ktokolwiek o coś podobnego mógł pomówić, a tym bardziej ja, który tak dobrze znam Ojca Generała i tak wysoki szacunek z dawien dawna mam dla Jego Osoby. Gdybym o coś podobnego Ojca Generała pomawiał, gdybym się dopatrywał u Ojca Generała jakiejś chęci walczenia z Ks. Ks. Biskupami, to bym

${ }^{28}$ Tenże, Metody badań zjawisk nadprzyrodzonych. Problem Konnersreuth, Kraków 1933.

${ }^{29}$ Łac.: przeciw wierze i obyczajom.

${ }^{30}$ Zob. w niniejszej publikacji: J. Wołczański, Korespondencja abp. Józefa Teodorowicza z bp. Henrykiem Przeździeckim, dokument 12. 
chyba nie zgłaszał się pierwszy do Ojca Generała z oświadczeniem w liście jakie dałem, iż nie mam przeciw temu, jeżeli O. Siwek odpowie mi na artykuły w „Ateneum”, skoro się godziłem na otwartą polemikę, to tym bardziej nie mogłem dopatrywać się w aprobacie Ojca Generała na pierwszą książkę jakiejś chęci walki z Ks. Ks. Biskupami. $\mathrm{Z}$ drugiej strony nie mogłem nie wspomnieć o dwu faktach, które wymieniłem w liście do O. Prowincjała.

Pierwszy fakt dotyczy ustępu bardzo znamiennego O. Siwka, w którym mi daje do poznania, co właściwie spowodowało wydanie jego książki. Pisze on: „Tamtego roku w październiku i listopadzie cały szereg wybitnych osobistości Krakowa zwracał się z sumieniem zakłopotanym do mnie w sprawie Konnersreuth. Dzisiaj dostaję cały szereg podziękowań - a figurują w nich imiona profesorów uniwers[yteckich] i członków Akademii Umiejętn[ości] ... List jednego z nich zacytowałem Waszej Ekscelencji... Ludzie tracą wiarę widząc pochopność niektórych w «zjawiskach nadprzyrodzonych». (Cały szereg moich kolegów na Sorbonie i w College de France potracili wiarę)". Ponieważ ta data listu odnosiła się do moich wykładów w Krakowie o Konnersreuth, dał mi więc O. Siwek niedwuznacznie do poznania, że właśnie moje wykłady były powodem zaniepokojenia, a nawet zachwiania wiary u moich słuchaczy, a wskazując tym samym na związek pomiędzy moimi wykładami a jego książką.

Drugim faktem była wzmianka w liście O. Siwka, że Ojciec Generał nie tylko mu dał pozwolenie na drukowanie jego książki, ale nawet dał mu wskazówki, w jaki sposób ma ją opracować. Ten pierwotny zakaz i następne pozwolenie pozwalały na doszukiwanie się przyczyny w podobnej zmianie. I tutaj ustęp O. Siwka o zgorszeniu, jakie wywołały dla wiary moje wykłady w Krakowie zdawał mi się być kluczem rozwiązującym dociekanie, co właśnie spowodowało tę - jak mi się wydawało - zmianę stanowiska Ojca Generała; ponieważ zaś sam o tym Ojcu Generałowi pisałem i Ojciec Generał dając mi odpowiedź na inne kwestie, tę pominął milczeniem, przeto w moich przypuszczeniach tylko tym więcej zostałem utwierdzony.

Jeżeli do tego dodam, iż Ks. B[is]k[u]p Lisowski ostrzegał O. Prowincjała, że wydanie pracy O. Siwka będzie uważane jako walka zakonnika z Ks. Ks. Biskupami, jeżeli do tego przydam drugie ostrzeżenie Ks. B[is]k[u]p[a] krakowskiego dane O. Rostworowskiemu w innej podanej formie, ale w treści mniej więcej takie samo, to książka O. Siwka pierwsza i druga ukazała się pomimo tych ostrzeżeń. Czy jednak stąd wyprowadziłem wnioski o jakiejś walce z Ks. Ks. Biskupami? Przenigdy! Właśnie w liście moim do O. Prowincjała, na który się Ojciec Generał powołuje całkiem wyraźnie piszę, że wolno się Ojcom nie oglądać się na te względy, które przecież nie tkwią w charakterze stosunku do Ks. Ks. Biskupów, ale tkwią w przekonaniu tego czy innego Ks. Biskupa o pewnym zgorszeniu opinii publicznej. Ta moja idea jest wyrażona w słowach: „... to jest ... dozwolone”.

Bo jest przecie zawsze dozwolone bez wywoływania walki jakiejkolwiek z Ks. Ks. Biskupami mieć inne zdanie o stanowisko w kwestii, która jest kwestią dyskusji. A więc po tak wyraźnym moim oświadczeniu musi być wykluczone wszelkie przypuszczenie, które by w sposób tak nieodpowiedni i niewłaściwy z mojej strony dosięgać mogło samej Osoby Ojca Generała. Jest to tym bardziej nie do pomyślenia, że najwyraźniej 
sformułowałem konkluzje wypływające z tych faktów; odnosiły się one do twierdzenia O. Prowincjała, iż książki O. Siwka zawierały kwestie „dysputabiles’’’1 i nie sięgały poza prywatną opinię O. Siwka. Otóż ja w odpowiedzi na to przytoczyłem te fakta na dowód, że w moim przekonaniu jednak tak nie jest; że wobec warunków w jakich ta książka powstanie i wobec motywów podanych przez jej autora, i wobec pozwolenia Ojca Generała następującego po poprzednim zakazie, książka ta ma pod pewnym względem charakter bojowy, o ile w przekonaniu O. Siwka broni zagrożonej wiary przez stanowisko zajęte w sprawie Konnersreuth przez dwu Ks. Ks. Biskupów.

A więc nie można mówić o tej książce, jako o czymś zupełnie oddzielonym od Zgromadzenia, bo zajęte stanowisko przez Zgromadzenie łączy się z tą książką. „To stanowisko - pisałem - wprawdzie jest dozwolone, ale trzeba stwierdzić, że przez to samo już pierwsza książka O. Siwka sprzęga się ze Zgromadzeniem”.

Prócz tego gdzie indziej podałem drugą jeszcze konkluzję, tę mianowicie, że wobec uprzedzenia przez Ks. B[is]k[u]p[a] Lisowskiego O. Prowincjała, iż Ks. Ks. Biskupi będą jednak bronić swej pozycji, o odpowiedzi O. Siwka nie mogli być Ojcowie choćby już z tego jednego powodu zaskoczeni moją polemiką w „Ateneum”. Czyli innymi słowy, zależało mi na wykazaniu, że wobec tych wszystkich precedensów Ojcowie sami ponoszą odpowiedzialność za logiczne następstwa wydanej książki w tych warunkach i takim ujęciu o Konnersreuth.

Sądzę, że po tym wyjaśnieniu z mej strony Ojciec Generał zechce łaskawie uchylić swoje przypuszczenie, jakobym miał na myśli jakąkolwiek walkę Ojca Generała z Ks. Ks. Biskupami.

Już tylko dodatkowo dotykam szczegółu o czytaniu manuskryptu O. Siwka przez O. Generała. Otóż to moje twierdzenie oparłem o list O. Siwka z dnia 17 I 1932 w którym pisząc, iż miał nie tylko pozwolenie Ojca Generała na wydanie tej książki, ale nadto jeszcze miał wytyczony kierunek obok pozwolenia, jakiego się ma trzymać w pisaniu książki, zaraz po tym dodaje: „Zaraz przy pierwszym widzeniu z O. Asystentem zakomunikował mi ten ostatni, że O. Generał przeczytał moją książkę i że jest z niej bardzo zadowolony, że tak doskonale odpowiada jego intencjom ...." (Podkreślenia O. Siwka).

Zdaje mi się, że wobec takiego tekstu było aż nadto usprawiedliwione moje przeświadczenie o przeczytaniu tej książki przez Ojca Generała wobec tak bezpośredniego udziału Ojca Generała pod pewnym względem, chociaż najogólniejszym, w programie tej książki.

Pozwolę sobie jeszcze zwrócić uwagę na szczegół listu Ojca Generała, w którym jest przytoczone moje zdanie w ten sposób, jakoby mi dziś nie szło o stronę doktrynalną, ale głównie i przede wszystkim zależy mi na stronie moralnej, która się wybija na czoło zagadnienia. Tak istotnie pisałem, ale mając na myśli przedstawienie przez O. Generała całego problemu sporu ze stanowiska li tylko kwestii „dysputabiles”. Otóż w tym znaczeniu od samego początku strony doktrynalnej kwestii podlegających dyskusjom, jak kwestia czy Konnersreuth jest zjawiskiem prawdziwym, czy też nie, nie zajmowałem

${ }^{31}$ Zniekształcony j. łac.: wątpliwe, sporne. 
się wcale. Pozostawiłem w tych sprawach wolność zupełną O. Siwkowi. Napisałem też O. Prowincjałowi, że o tę kwestię wcale tu nie chodzi dzisiaj.

Wyświetlając właściwy sens tych moich słów, pragnąłbym uniknąć wobec Ojca Generała pomówienia mnie o to, jakoby mi dziś nie zależało na kwestii doktrynalnej w innym znaczeniu, aniżeli to poruszyli Ojcowie w liście pisanym do mnie. Byłaby to z mojej strony podobna rezygnacja wprost dziwna, skoro dla tych kwestii podjąłem się pisać rozprawę z O. Siwkiem i skoro takim olbrzymim nakładem czasu i pracy tę rozprawę uzupełniłem dziś całą książką.

Otóż, do tego drugiego dzieła O. Siwka na które właśnie odpowiedzią była moja książka, nie mam żadnych pretensji doktrynalnych pod względem zasadniczym, t.j. w uwzględnieniu kryteriów mistycznych przez O. Siwka w drugiej książce bez względu na to, jakiej wartości naukowej są te kryteria. W mojej książce nawet poświęciłem cały rozdział wykazaniu, że pod względem zapatrywań na metody badań, idee o ekstazach etc., O. Siwek powtórzył za mną w drugiej książce to wszystko, choć w sposób sobie właściwy, co ja w rozprawie swojej w „Ateneum” rozprowadziłem. Ale właściwy mój zarzut w odniesieniu do jego pierwszej książki, iż przesądza o kryteriach mistycznych wyłącznie przez analogię z psychopatią etc., ten pozostaje.

Zresztą sam O. Siwek nie tylko w swej pierwszej książce, nie tylko w sposobie odpowiedzi danej mi w książce drugiej, ale nawet w dwóch swoich listach pisanych do mnie wyraźnie się do tego przyznaje, że mistyki jako takiej w swej pierwszej pracy nie uwzględnia; ja zaś nic więcej nie twierdziłem ponad to, co sam O. Siwek przyznaje. Ale te twierdzenia jednak podtrzymuję, bo one są faktami, z których konkluzje narzucają się już same.

Jeżeli zaś pisałem o moralnym czynniku w tej całej sprawie, to umotywowałem to aż nadto wyraźnie w liście moim do O. Prowincjała. Tak powoływanie się O. Siwka na zupełnie zniekształconą przez niego myśl mojego listu, jak sfałszowanie tendencyjne wszystkich moich tez naukowych, jak przedstawienie mnie za człowieka, który błądzi contra doctrinam christianam ${ }^{32} \mathrm{w}$ sprawie proroctw, jak wreszcie atakowanie mnie na publicznym wykładzie w Rzymie wobec międzynarodowego audytorium z kpinami ironicznymi i aluzjami - to wszystko razem chyba aż nadto usprawiedliwia to, co napisałem o stronie moralnej w całej tej nieszczęsnej kwestii.

Do tych szczegółów dodam teraz zupełnie nowy. Oto pojawiły się niedawno artykuły na szpaltach "Czasu” 33 i „Dziennika Poznańskiego"34 tak przejrzyście wskazujące na źródło skąd wyszły, że Ks. Biskup krakowski nie zawahał się wystosować list do Ojców krakowskich potępiający podobne metody. Co do mnie to sądzę, że się nie omylę, jeżeli źródła będę się doszukiwał nie w środowisku Ojców, ale wprost u Siwka. W każdym razie autor artykułu na szpaltach „Czasu” i „Dziennika Poznańskiego” w uderzający spo-

${ }^{32}$ Łac.: przeciwko chrześcijańskiej doktrynie.

${ }_{33}$ Zob. w niniejszej publikacji: J. Wołczański, Listy abp. Józefa Teodorowicza do abp. Józefa Bilczewskiego, dokument 18.

34 „Dziennik Poznański” - informacyjno-publicystyczna gazeta liberalna o programie narodowym założona przez Hipolita Cegielskiego w Poznaniu. Periodyk ukazywał się w l. 1859-1939. J. Łojek, J. Myśliński, W. Władyka, Dzieje prasy polskiej, Warszawa 1988, s. 41, 60-61. 
sób przypomina nie tylko sposób pisania, ale wszystkie metody polemiczne, jakimi operuje w swej drugiej książce przeciw mnie O. Siwek. A więc przede wszystkim autor obu tych artykułów pomimo wskazania w mojej książce fałszerstwa O. Siwka, ażeby za cenę sfałszowania tez zmienić istotny charakter moich zarzutów, jednak znowu piosnkę tę O. Siwka odtwarza. A więc nie zależało mi - wedle tego autora tak samo jak poprzednio wedle założeń odpowiedzi O. Siwka - na wykazaniu powierzchowności, jednostronności i nieścisłości naukowej w książce O. Siwka, ale atakuję go rzekomo właśnie za jego wiedzę ścisłą, poważne i słuszne naukowe argumenty tak, że on pada ofiarą naiwnej, bezkrytycznej mojej łatwowierności. Przemilcza ten autor, iż to O. Siwek czynił mi zarzut nieprawowierności w sprawie proroctw, a podsuwa go znowu mnie samemu, który się tak jasno zastrzegałem, że nie pomawiam osobiście O. Siwka znając jego wiarę głęboką o racjonalizm, owszem, wiem, że ten racjonalizm zwalcza. Te więc wykrętne metody podyktowane złą wiarą uderzają zaraz na pierwszy rzut oka zarówno czytelnika "Metod"35, jak i czytelnika obu tych artykułów. Dalej, uderza w nich ten ton niesłychanej zarozumiałości i pewności siebie jeszcze utrzymany w rezerwie w książce O. Siwka, ujawniający się tylko w ironii źle ukrytej i łaskawym pouczaniu mnie wszędzie. Tutaj jednak autor już się posuwa do reklamy dla O. Siwka w sposób tak nadęty, że to się staje aż śmieszne.

Kłamstwo i pycha, oto dwie cechy wspólne zarówno w książce O. Siwka, jak i w tych dwu artykułach w zamaskowany sposób uderzające na mnie przed forum opinii, u której się liczy i poluje na nieznajomość rzeczy; przy tym autor obu tych artykułów widocznie przebywa w Rzymie, choć się żywo interesuje wrażliwością Krakowa, a z którym jest widocznie związany. Już przedtem agent O. Siwka, ks. Weryński ${ }^{36}$ piszący pod pseudonimem „Miel”, akcentował w „Kurierku”" ${ }^{37}$ krakowskim, że książka O. Siwka pokaże się w typografii watykańskiej; w Katolickiej Agencji Prasowej znowu występuje Watykan choćby tylko w adresie: Citta Vaticana. A teraz autor artykułu udaje się pod skrzydła jeszcze nikomu niewiadomej encykliki papieskiej o nauce, ażeby stamtąd razić strzałami „bezkrytycznych i naiwnych recenzentów” mej książki, pośrednio więc mnie samego.

Daruje mi Ojciec Generał, że tak się o tym rozpisuję, ale boję się bardzo, że zainagurowana metoda w artykułach "Czasu” i „Dziennika Poznańskiego" uderzenia na mnie nie już z otwartą przyłbicą, ale z tyłu, gotowa się dalej przeciągać.

Pozwoli Ojciec Generał, że korzystając z tej sposobności, wyrażę Ojcu Generałowi moją najgłębszą cześć i mój najoddańszy szacunek, sługa w Chrystusie.

Lwów, dnia 26 lutego 1934

${ }^{35}$ Aluzja do dzieła o. Siwka: Metody badań zjawisk nadprzyrodzonych. Problem Konnersreuth, Kraków 1933.

${ }^{36}$ Zob. w niniejszej publikacji: J. Wołczański, Korespondencja abp. Józefa Teodorowicza z abp. Adamem Stefanem Sapieha, dokument 101.

37 Właściwie: „Ilustrowany Kurier Codzienny”. Zob. w niniejszej publikacji: J. Wołczański, Korespondencja abp. Józefa Teodorowicza z abp. Adamem Stefanem Sapiehą, dokument 104. 


\section{Dokument 11}

Oryg.: AFKDOPW, teczka 141: Spuścizna abp. Józefa Teodorowicza, sygn. 941/420 (8) [7], List o. Włodzimierza Ledóchowskiego SJ do abp. Józefa Teodorowicza, Rzym 29 III 1934 r.

Rzym, dnia 29 marca 1934

Ekscelencjo ${ }^{\mathrm{a}}$, Najprzewielebniejszy Księże Arcybiskupie!

Z powodu nowych zajęć nie mogłem wcześniej odpowiedzieć na list Waszej Ekscelencji z dnia 26 lutego, za który najuprzejmiej dziękuję.

Serdecznie się cieszę, że Wasza Ekscelencja stanowczo oświadcza, że to, co było dla mnie szczególniej bolesne, o tym nie ma nawet mowy, ani nikt nie myśli zarzucać mi „walkę z Ks[iężmi] Biskupami”, czy brak czci i szacunku względem nich. Muszę jednak powiedzieć, że przeczytawszy jeszcze drugi raz list Waszej Ekscelencji pisany do O. Prowincjała w styczniu zdaje mi się, że trudno dla mnie było list inaczej zrozumieć, gdyż oprócz jednego zdania: „To wprawdzie jest dozwolone”, cały prawie list zdawał się być oskarżeniem o ciężką winę moralną, która ostatecznie da się streścić w nieuszanowaniu Księży Biskupów; teraz jednak wobec oświadczenia Waszej Ekscelencji w liście do mnie pisanym jestem co do tego zupełnie spokojny.

Wobec tego jednak, że Wasza Ekscelencja jest zdania, iż ja w wyjątkowy sposób zająłem się książką O. Siwka i także w wyjątkowy sposób dałem aprobatę i nakaz, by była drukowana, sądzę, iż dla wyświetlenia prawdy muszę oświadczyć Waszej Ekscelencji, że $i$ to zupełnie nie odpowiada rzyczywistości. W całej tej sprawie, nie wchodząc w drobne szczegóły, rola moja była taka, że z początku, kiedy wyszły pierwsze artykuły o Konnersreuth, posłałem list do Prowincji, w którym dałem zakaz, żeby w tej kwestii nie pisano ani pro, ani contra; potem ograniczałem się do [sprawdzania] tego, czy ten zakaz jest zachowany. Skoro uznałem, że książka O. Siwka nie wykracza przeciw memu zakazowi, powiedziałem o tym O. Prowincjałowi, zostawiając mu najzupełniej nie tylko prawo, ale i obowiązek jaki na Prowincjale ciąży poddania tę książkę pod ocenę cenzorów czy ona godna jest by mogła być drukowana. Zachowanie się więc moje w tej kwestii, jak Ekscelencja widzi, było tylko tego rodzaju, czy książka O. Siwka podpada pod mój zakaz i nic więcej, tak że ani mowy być nie może o jakimś nakazie jej drukowania z Rzymu, jak to Wasza Ekscelencja mi pisze, „że Rzym rozstrzygnął tę kwestię”.

Co się zaś tyczy słów wyjętych z mego listu do Waszej Ekscelencji z dnia 2 maja 1932 r., „że w danych warunkach muszę pozwolić na odpowiedź”, pozwalam sobie zwrócić uwagę, że te słowa nie odnoszą się do pierwszej książki O. Siwka, ale do późniejszej obrony O. Siwka. Stwierdziłem w tym liście tylko to, co musiałem stwierdzić, że jeżeli ktoś jest zaatakowany o prawowierność nauki katolickiej, wtedy nie mogę zabraniać mu by się bronił, bo do tego każdy człowiek, także biedny zakonnik ma prawo już z samego prawa natury; ale pozwalając na to, nie wchodzę w meritum samej obrony; cała ta rzecz należy zawsze do O. Prowincjała.

a Tekst pisany na maszynie $\mathrm{z}$ wyjątkiem autografu autora na siedmiu kartach papieru formatu A4. W prawym górnym rogu karty tytułowej nota ręką archiwisty: „941/420(80 [7]”. 
Najważniejsza jeszcze zostaje rzecz, którą Wasza Ekscelencja w liście do mnie „tylko dodatkowo dotyka", to czytanie przeze mnie manuskryptu O. Siwka. Zdaje mi się, że Wasza Ekscelencja nie miał powodu do takiego twierdzenia na podstawie przytoczonych przez Waszą Ekscelencję cytatów z listów, a tym bardziej zdaje mi się, nie mógł pisać do Ks. Biskupa Przeździeckiego ${ }^{38}$, że O. Siwek pisał do Waszej Ekscelencji, „iż sam O. Generał przeczytał jego rękopis osobiście i zaaprobował go", chyba żeby Wasza Ekscelencja miał inny list O. Siwka niż ten przytoczony w liście do mnie z 17 stycznia 1932 r., ale tego nie mogę suponować.

Co do cytatów z listu O. Siwka, to bez wątpienia zawierają one słowa przesadne, które mogą być mylnie tłumaczone, ale pozwalam sobie zwrócić uwagę, że jak mój poprzednik $^{39}$, znakomity kanonista, słusznie podnosił, iż nie można nigdy szukać w zwyczajnych listach i rozmowach kanonicznej ścisłości - mówił o zwykłych swych listach - i trzeba je zawsze tłumaczyć nie tylko z kontekstu, ale z całego stanu sprawy; inaczej można by łatwo dojść do konkluzji niemożliwych i z prawdą zupełnie niezgodnych, jakeśmy to widzieli w smutnych walkach tak zwanych integrystów. Także O. Asystent, choć naturalnie nie przypomina sobie dokładnie słów powiedzianych do O. Siwka może zaręczyć, że tylko miał na myśli zgodność książki O. Siwka z moim poleceniem, a nic innego. Zresztą Wasza Ekscelencja rozumie, że takie moje postępowanie, żebym ja bez czytania książki i bez zdania cenzorów dał nakaż drukowania książki byłoby w wysokim stopniu nie tylko po prostu nierozumnym, ale wprost przeciwnym naszemu Instytutowi. A mogę powiedzieć, że chociaż jestem słaby i ułomny, sumienie mi jednak świadczy, że zawsze, przede wszystkim w tej materii trzymałem się przepisów Instytutu, co także wszyscy Asystenci zeznać mogą i czegoś wręcz przeciwnego nikt nie będzie mógł udowodnić. Stanowczo więc muszę oświadczyć, że wszystko co mi Wasza Ekscelencja przypisał: że ja czytałem manuskrypt O. Siwka, że kierowałem całą sprawą w sensie przez Waszą Ekscelencję podanym, że mimo oświadczenia Ks[ięży] Biskupów żeby oświetlić kwestię mistyki dałem nakaz drukowania książki O. Siwka itd., nie odpowiada rzeczywistości. A w szczególności co do tego „dezawuowania” Ks[ięży] Biskupów, do którego Wasza Ekscelencja tak często w Swych listach powraca mogę oświadczyć, że nic o nim nie wiedziałem, a nawet przypuszczać takiego postawienia kwestii nie mogłem, tak ono mi się zdaje dziwnym i niezgodnym z przyjętym powszechnie i tradycją wiekową popartym sposobem postępowania w podobnych sprawach.

Przy tej sposobności sądzę, że muszę także wyjaśnić sprawę listu Ks. Biskupa Przeździeckiego pisanego z Rzymu do Waszej Ekscelencji. Z tego listu Wasza Ekscelencja wnioskował, że w sprawę tłumaczenia książki Waszej Ekscelencji chce się wciągnąć Św[ięte] Officium i niejako nim grozić. Pozwalam sobie zwrócić uwagę Waszej Ekscelencji, że list Ks. Biskupa Przeździeckiego wprawdzie był niejasny, bo naprędce pisany, ale z niego z pewnością nie wynikało, że Św[ięte] Officium zajmuje się sprawą tłumaczenia

${ }^{38}$ Zob. w niniejszej publikacji: J. Wołczański, Listy abp. Józefa Teodorowicza do abp. Józefa Bilczewskiego, dokument 148.

${ }^{39}$ Poprzednikiem o. Ledóchowskiego na urzędzie generała Zakonu oo. Jezuitów był o. Franciszek Ksawery Wernz w l. 1906-1914. 
książki Waszej Ekscelencji i że ze strony jego są jakieś pod tym względem plany. Sens listu Ks. Biskupa Przeździeckiego był ten, że Sam Ekscelencja z zarzutami mógłby się zwrócić do Św[iętego] Officium. Rozmowę z Ks. Biskupem Przeździeckim najdokładniej pamiętam. Wyraziłem przed nim żal głęboki z powodu całej tej polemiki, dlatego osobisty, że pochodzi od Dostojnika, z którym łączyły mnie dawniej tak ścisłe węzły do tego stopnia, że ilekroć był ciężko atakowany zawsze najserdeczniej go broniłem, a teraz słyszę, że chce obecną sprawę rozciągnąć nawet i na inne kraje. Prosiłem wtedy Ks. Biskupa Przeździeckiego, czy nie mógłby w tej sprawie pośredniczyć. Mówiłem, jak zupełnie inaczej w podobnych wypadkach rzecz się przedstawiała w takich np. Niemczech czy Francji. Kiedy tam jeden, drugi Ojciec poszedł za daleko i było nawet niebezpieczeństwo, że może Św[ięte] Officium tą sprawą się zajmie, to Księża Biskupi z własnej woli stawali w obronie naszego Ojca, bo nie jest to w interesie Kościoła jakiegoś kraju, jeżeli jacyś jego księża są podejrzani o prawowierność, a tutaj, kiedy mi się zdaje, że i dla Polski coś zrobiłem, nawet profesora Uniwersytetu jakieś błędy są tak rozgłaszane. Sądzę, mówiłem, znając głęboką miłość Waszej Ekscelencji do Polski, że zamiast polemiki lepiej by było, jeżeliby Wasza Ekscelencja zwrócił się do Św[iętego] Officium i przedłożył niebezpieczeństwo, jakie mogłoby Kościołowi z tej książki zagrażać. Chociaż Wasza Ekscelencja o zarzucie co do Św[iętego] Officium później w listach już nie mógł mnie o coś podobnego podejrzewać, nie mogłem sobie w inny sposób wytłumaczyć, jak tylko silnym podnieceniem pod wpływem może nie dość jasnego listu Ks. Biskupa Przeździeckiego. Wszak podobne postępowanie, które się Waszej Ekscelencji na myśl nasunęło byłoby z mej strony niesłychanie niemądrym. Od 26 lat jestem w Rzymie i znam może lepiej niż wielu innych sposób postępowania Kongregacji rzymskich, a w szczególności Św[iętego] Oficium i wiem dobrze, jak sekret jest tu ściśle zachowany; zresztą byłbym sam związany sekretem Św[iętego] Officium gdybym nawet coś podobnego wiedział. Oprócz tego taki sposób postępowania byłby z mojej strony niską intrygą, a z łaski Bożej prócz Recaldó $w^{40}$ i Bremeró ${ }^{41}$ nikt mi tego jeszcze nie zarzucił.

Niech mi Ekscelencja wybaczy, że nieco dokładniej wszystkie te szczegóły opowiedziałem, ale sądziłem, że jako przełożony zakonu jest moim obowiązkiem wyświetlić jasno całą sprawę. Wasza Ekscelencja na końcu swego listu stawia także bardzo ciężkie zarzuty przeciw O. Siwkowi; sądzę, że lepiej na nie będzie odpowiedzieć osobnym listem.

Całując ze czcią najgłębszą pierścień Waszej Ekscelencji, z pokorą proszę o Arcypasterskie błogosławieństwo, sługa w Chrystusie

Jego Ekscelencja

Najprzew[ielebniejszy] Ksiądz Arcybiskup

Józef Teodorowicz

Lwów

${ }^{40}$ Osoba niezidentyfikwana.

${ }^{41}$ Osoba niezidentyfikowana.

b-b Autograf pisany czarnym atramentem. 


\section{Dokument 12}

Oryg.: AFKDOPW, teczka 141: Spuścizna abp. Józefa Teodorowicza, sygn. 942/420 (8) [7], List o. Włodzimierza Ledóchowskiego SJ do abp. Józefa Teodorowicza, Rzym 31 III 1934 r.

Rzym, dnia 31 marca 1934

Ekscelencjo ${ }^{a}$, najprzewielebniejszy Księże Arcybiskupie!

Wobec tego, że Wasza Ekscelencja na końcu Swego listu do mnie pisanego ${ }^{42}$ bardzo surowe sądy wydaje o O. Siwku mówiąc, że „metody jego podyktowane są złą wiarą uderzającą zaraz na pierwszy rzut oka”, dalej, że „kłamstwo i pycha są cechą jego książki” sądzę, że moim obowiązkiem, jako przełożonego O. Siwka, którego od wielu lat dość blisko znam jest powiedzieć Waszej Ekscelencji z całą szczerością, że tego rodzaju zarzuty uważam za niesłuszne i obiektywnie ciężko O. Siwka krzywdzące.

Naprzód co do złej wiary, to Wasza Ekscelencja wie i każdy, kto miał więcej z ludźmi do czynienia dobrze zdaje sobie z tego sprawę, jak niesłychanie trudno udowodnić komuś złą wiarę. Często gdzie pozory są, gdy się bliżej rzecz zbada widać, że tam wcale złej wiary nie ma i dlatego Francuzi słusznie mówią: „tout savoir, c'est tout pardoner" ${ }^{\text {”33 }}$. Im dłużej jestem w rządach, tym lepiej widzę, jak prawdziwym jest to przysłowie i lepiej rozumiem dlaczego Pan Jezus tak surowo ostrzega, by nie sądzić drugich. Co do mnie, pozytywnie mogę świadczyć, że czegoś podobnego u O. Siwka wcale nie ma i sądzę, że nikt nie będzie w stanie udowodnić mu prawdziwie złą wiarę.

Co się zaś tyczy zarzutu pychy, oczywiście, że w każdym z nas łatwo takie osobiste wchodzą względy; nawet u ludzi świątobliwych motywy miłości własnej mogą występować w pewnych wypadkach i odgrywać swoją rolę.

Jeśli chodzi o kłamstwo, zarzut ten zdaje mi się także obiektywnie krzywdzący O. Siwka, gdyż formalnego i świadomego sfałszowania prawdy nie można mu udowodnić. Dla przykładu biorąc chociażby tylko cytat przytoczony w książce Waszej Ekscelencji „Zjawiska mistyczne i ich tłumaczenia" na str[onicy] 218, pozwalam sobie zwrócić uwagę, że inni poważni ludzie i to nie zanadto przychylni dla O. Siwka odnieśli wrażenie, iż nie widzą tego fałszowania. Inna jest rzecz, że mogą się u O. Siwka zdarzać pewne niejasności i niedociągnięcia, nawet sprzeczności, co oczywiście przy większej ekscytacji łatwo może mieć miejsce. Ile razy widzimy przede wszystkim tu w Rzymie - a wiem, że osoby wyżej położone to samo stwierdzają - jak głęboką prawdę psychologiczną zawiera znany aksjomat schalastyków: „Quidquid recipitur, secundum modum recipientis recipitur $^{\prime 34}$. Stąd się zdarza, że ludzie poważni, o których dobrej wierze wątpić nie można, czasem zupełnie przemieniają to, co im się powiedziało.

A może i w sformułowaniu zarzutów moralnych, które Wasza Ekscelencja O. Siwkowi czyni, pewne niedokładności się wkradły. I tak, żeby tylko wytknąć kilka punktów, Wasza

a Tekst pisany na maszynie z wyjątkiem autografu na ośmiu stronicach papieru formatu A4. W prawym górnym rogu karty tytułowej nota ręką archiwisty: „942/420(8) [7]”.

${ }^{42}$ Zob. dokument 10 niniejszej części publikacji.

${ }^{43}$ Fr.: wszystko wiedzieć, to wszystko wybaczyć (cała umiejętność to całkowite wybaczenie).

${ }^{44}$ Łac.: cokolwiek jest przyjmowane do czegoś, jest odbierane zgodnie ze stanem odbiorcy. Św. Tomasz z Akwinu, Summa Theologiae, 1a, q. 75, a. 5; 3a, q. 5. 
Ekscelencja w liście do J[ego] E[minencji] Księdza Prymasa pisał ${ }^{45}$, że O. Siwek przez agenta swego Ks. Weryńskiego aż telegraficznie z Città Vaticana w K.A.P. zapowiedział swoją odpowiedź. Tymczasem w rzeczywistości O. Siwek nie miał tutaj najmniejszego udziału.

Co się zaś tyczy rozmów Waszej Ekscelencji z O. Siwkiem w Krakowie, to chyba nie chodziło tylko o półgodzinną rozmowę; O. Siwek ma daty najdokładniejsze i gotów jest przysięgą stwierdzić, że rzeczy zupełnie inaczej się przedstawiają.

Pozwalam sobie też zapytać się Waszą Ekscelencję, czy w liście do redakcji „Szkoły Chrystusowej" O. Siwek, którego list przysłano Waszej Ekscelencji rzeczywiście pisze, że Wasza Ekscelencja jest oszczercą, czy tylko obiektywnie wydają mu się zarzuty stawiane przez Waszą Ekscelencję oszczerstwami.

W sprawie zaś tej ogromnej reklamy O. Siwka, o której Wasza Ekscelencja z tak wielkim oburzeniem pisze zdaje mi się, że reklama zrobiona z drugiej strony jest bez porównania większa: w pismach najróżniejszych odcieni, politycznych, naukowych, popularnych, w miesięcznikach, tygodnikach, pismach codziennych przedstawia się O. Siwka pod względem moralnym i intelektualnym w jak najgorszym świetle, aby go zniszczyć - nie mogę znaleźć innego wyrazu - w opinii publicznej. Pisał Wasza Ekscelencja, że chce zostać na terenie dyskusji ściśle naukowej. Ale czy można powiedzieć, że artykuły ${ }^{46}$ ks. kan[onika] Bogdanowicza ${ }^{47}$ są dyskusją naukową? Czy to nie jest reklama i to niska, oburzająca każdego, który zna sprawę dokładnie, a tym bardziej oburzająca, że się wie, iż przeciwnik przynajmniej na razie odpowiedzieć nie może. A ponieważ ks. Bogdanowicz nieraz się podpisuje: „Kanonik Lwowskiej Kapituły obrz[ądku] orm[iańskiego]" i także list prywatny do Waszej Ekscelencji pisany cytuje, to mimo woli może nasuwać się myśl, że nie bez wiedzy Waszej Ekscelencji działa. Czy Ekscelencja nie powinien temu koniec położyć choćby tylko dla własnego dobrego imienia?

Co się zaś tyczy doniesienia, o którym Wasza Ekscelencja pisze do J[ego] E[minencji] Ks. Prymasa dnia 31 stycznia, że „pod wpływem OO. Jezuitów i Gregorianum w Rzymie broszura O. Siwka skierowana przeciwko mnie rozchodzi się w Niemczech"48, to jest ono z gruntu fałszywe; i tak Ekscelencja widzi, jak elementa widocznie niedobrze dla Towarzystwa usposobione Ekscelencję w błąd wprowadzają.

A tu muszę jeszcze wzmiankę uczynić o ciężkich obrazach, jakie O. Siwek miał Waszej Ekscelencji wyrządzić. Rzeczywiście w książkach tych ciężkich obraz nie widzę, a inni także ich nie widzieli; mógł się pomylić w pewnych zarzutach Waszej Ekscelencji czynionych, mogło mu się wymknąć słowo, ale to są rzeczy, które w dyskusji łatwo się zdarzają, a w każdym razie są one niczym w porównaniu - niech Wasza Ekscelencja wybaczy - z gryzącą ironią, cierpkim sarkazmem, zgryźliwymi porównaniami, które w książce Waszej Ekscelencji się znajdują. Na swoich wykładach zaś O. Siwek raz tylko

${ }_{45}$ Zob. w niniejszej publikacji: J. Wołczański, Korespondencja abp. Józefa Teodorowicza z różnymi osobami w sprawie Teresy Neumann, dokument 176.

46 A. Bogdanowicz, O logike w mistyce, GK, 41(1934), s. 80-82, 132-134.

47 Zob. w niniejszej publikacji: J. Wołczański, Listy abp. Józefa Teodorowicza do abp. Józefa Bilczewskiego, dokument 141.

${ }^{48}$ Zob. w niniejszej publikacji: J. Wołczański, Korespondencja abp. Józefa Teodorowicza z różnymi osobami w sprawie Teresy Neumann, dokument 176. 
Waszą Ekscelencję wymienił, a za to dostał surowe upomnienie, choć z katedry uniwersyteckiej się nieraz także z żyjącym dostojnikiem polemizuje; nie jest zaś obrazą twierdzić, że ktoś nie jest w pewnych kierunkach fachowo wykształcony. Zresztą Wasza Ekscelencja, zdaje mi się, wyolbrzymia fakt, na który nikt prawie nie zwrócił uwagi; ja sam tylko o wiele później o tym się dowiedziałem, a O. Siwek jak najchętniej gotów przeprosić za to, w czym zawinił.

A teraz jeszcze kilka słów, co do strony bardziej doktrynalnej. Kazałem książkę O. Siwka przetłumaczyć zupełnie dokładnie na język francuski tylko w tym celu, żeby była jak najściślej zbadana przez kompetentne osoby i zupełnie spokojnie patrzące się na całą sprawę. Sąd ich był tego rodzaju, że ta książka zawiera wiele braków i dlatego już nieraz żal wyraziłem, że w Prowincji cenzura była niedokładnie wykonana, ale równocześnie wszyscy jednogłośnie orzekli, że ciężkie zarzuty stawiane przez Waszą Ekscelencję O. Siwkowi są niesłuszne i krzywdzące.

Zdaje mi się, że gdyby w sprawie O. Siwka zastosowało się tak piękne zdanie św. Ignacego umieszczone zaraz na wstępie jego rekolekcji: „Supponendum est, Christianum unumquemque pium, debere promptione animo sententiam seu propositionem obscuram alterius in bonam trahere partem, quam damnare ${ }^{39}$, co jest zresztą streszczeniem opisu miłości św. Pawła, to by z pewnością O. Siwek nie był tak zniesławiany; tym bardziej, że Ekscelencja dobrze rozumie, iż Wasza Ekscelencja znajduje się w warunkach bez porównania lepszych dla Swej godności Arcybiskupiej niż O. Siwek, który choćby mu dozwolono pisać, nie mógłby ze względu na godność Biskupa tak otwarcie pisać, jak Wasza Ekscelencja.

Wasza Ekscelencja pisze, że na ewentualną odpowiedź O. Siwka zachował jeszcze pewne dokumenty, których dotąd nie opublikował, a które byłyby dla O. Siwka prawdziwie druzgocące. Jest możliwym, choć pewnych danych nie mam, że O. Siwek, który jest nerwowym człowiekiem jakieś nieroztropne listy napisał albo coś powiedział, zwłaszcza, gdy był silnie podniecony, co by mogło bardzo zaszkodzić gdyby było publikowane. Ale czy raczej nie należy bać się, by przeciwnika nie zdruzgotać? A tu niech mi wolno będzie zwrócić uwagę Waszej Ekscelencji, że i bez tej publikacji to niebezpieczeństwo istnieje. O. Siwek nie ma silnego zdrowia, to zniesławianie go po całej Polsce, które aż dotąd w milczeniu przyjmować musi, tak na jego nerwy oddziaływa, że prawdziwe niebezpieczeństwo istnieje, iż człowiek, który jak to inne jego prace wskazują mógłby z niemałym pożytkiem dla Kościoła i chwały dla Polski pracować, zupełnie niezdolnym do pracy się stanie.

Sądzę, że w tego rodzaju warunkach jest obowiązkiem obu stron, żeby dążyły do zakończenia tej tak przykrej sprawy, która i Waszej Ekscelencji, i innym nie widać z jakim pożytkiem tyle cennego w tak ciężkich chwilach Kościoła czasu zajmuje, a zdaje mi się, że przy dobrej woli to nie będzie tak trudnym.

Wasza Ekscelencja w Swoim liście z dnia 23 listopada 1933 r. do Ks. Biskupa Przeździeckiego oświadcza: „że w rzeczach zasadniczych tj. w zapatrywaniach na metody traktujące

${ }^{49}$ Łac.: Należy wysunąć wniosek, że każdy pobożny chrześcijanin powinien z ochotą zdanie lub ukryty zamiar innej osoby poczytywać raczej na jej korzyść (tzn. oceniać jako dobrą intencję), niż potępiać. 
o rzeczach mistycznych zgadzamy się zupełnie"50, a w innej formie mnie więcej to samo Wasza Ekscelencja w liście do mnie z dnia 26 lutego br. Pisze: „Otóż do tego drugiego dzieła O. Siwka, na które właśnie odpowiedzią była moja książka, nie mam żadnych pretensji doktrynalnych pod względem zasadniczym..." ${ }^{51}$ - z drugiej zaś strony Wasza Ekscelencja często wspomina o zgorszeniu z prowadzenia tej polemiki. Wobec tego zdaje mi się, że będzie można łatwo położyć koniec tej sprawie obustronnym oświadczeniem, które jednocześnie mogłoby być ogłoszone np. w „Ateneum Kapłańskim”. Wasza Ekscelencja mógłby oświadczyć, że porozumiawszy się z O. Siwkiem doszedł do przekonania, iż O. Siwek nigdy nie hołdował bynajmniej metodom niezgodnym z duchem Kościoła katolickiego, ani nie wyraził żadnej opinii, która by stała w sprzeczności z Teologią Katolicką lub stanowić miała niebezpieczeństwo dla św[iętej] wiary; również nie napisał nic takiego, co by uwłaczało jego dobremu imieniu czy to jako profesora Uniwersytetu, czy jako kapłana i zakonnika.

O. Siwek zaś ze swej strony mógłby oświadczyć, że nigdy nie miał intencji zarzucać Waszej Ekscelencji czegokolwiek, co by nie było w doskonałej zgodzie z Teologią Katolicką lub co by nie harmonizowało z wymogami metody naukowej lub zdrowej krytyki zaleconej przez Kościół w badaniach zjawisk nadprzyrodzonych; również mógłby oświadczyć, że nigdy nie miał zamiaru uwłaczać w czymkolwiek Waszej Ekscelencji.

Naturalnie, tekst dokładny tych oświadczeń musiałby być ułożony za wspólnym porozumieniem.

Ufam w Panu Bogu, że Wasza Ekscelencja przyjmie tę propozycję; w przeciwnym bowiem razie nie pozostawałaby inna droga, jak tylko udać się z tą sprawą do Stolicy Świętej.

Całując ze czcią najgłębszą pierścień Waszej Ekscelencji, z pokorą proszę o Arcypasterskie błogosławieństwo, najniższy sługa w Chrystusie

Wł[odzimierz] Ledóchowski SJ ${ }^{\mathrm{b}}$

Jego Ekscelencja

Najprzew[ielebniejszy] Ksiądz Arcybiskup

Józef Teodorowicz

Lwów

\section{Dokument 13}

Kopia: AFKDOPW, teczka 132: Spuścizna abp. Józefa Teodorowicza, sygn. 1604/185 [4], Kopia pisma abp. Józefa Teodorowicza do o. Włodzimierza Ledóchowskiego SJ, Lwów 14 V 1934 r.

Très-Révérend ${ }^{a}$ Père Général!

Je viens de recevoir deux lettres de Votre part et j'y réponds en Vous remerciant.

${ }^{50}$ Zob. w niniejszej publikacji: J. Wołczański, Korespondencja abp. Józefa Teodorowicza z bp. Henrykiem Przeździeckim, dokument 12.

${ }^{51}$ Zob. w niniejszej części publikacji dokument 10.

b Autograf czarnym atramentem.

a Tekst pisany maszynowo na 6 stronicach papieru formatu A4. Brak autografu autora. 


\section{Votre participation dans cette question}

Je vois que Vous trouvez que les paroles de ma lettre quant à Votre rôle, concernant la publication des deux livres du Père Siwek, qu'il était permis de faire ce qui a été fait, expriment trop peu et ne mettent pas assez en relief Votre éloignement de l'affaire. Je me permets de Vous rappeler que je ne me suis défendu dans ma dernière lettre seulement contre Votre accusation, que je Vous reproche de vouloir lutter avec les Evêques. Je pense que pour écarter cette accusation, les paroles dont je me suis servi et que Vous citez, Très-Révérend Père, sont tout à fait suffisantes. Mais convenez que j'ai été forcé d'envisager l'affaire avec le P[ère] Siwek comme je l'ai fait, en trouvant que la responsabilié morale repose en grande part sur Vous, Très-Révérend Père.

Les citations de P[ère] Siwek, se rapportant aux éloges exceptionnels, que Vous lui aviez donnés par l'assistant après la lecture du manuscrit - de même que la défense de publier l'article du „Przegląd”, où le P[ère] Siwek était très peu engagé, puis la lettre du $\mathrm{P}$ [ère] Rostworowski ${ }^{52}$, adressée par lui à Son Excellence l'Archevêque de Cracovie, où il lui mande d'avoir reçu de Rome un ordre précis de publier le second livre du P[ère] Siwek, enfin la liaison morale entre l'indication sur moi, comme sur celui, qui par ses conférences à Cracovie Soi-disant a suscité de l'inquiétude dans les coeurs croyants tout ceci pris en total est si clair et si éloquent, que je ne pouvais juger autrement Votre rôle, mon Père, que comme je l'ai fait dans ma lettre au Père Provincial.

\section{Pourquoi ai-je écrit une critique du livre du P[ère] Siwek?}

Vous me reprochez en première ligne d'avoir écrit en général une critique du livre du P[ère] Siwek.

Il me reste la réponse à Votre proposition, présentée à S[on] Exc[ellence] l'Evêque Przeździecki ${ }^{53}$, de laquelle Vous m'écrivez maintenant. Cette proposition est venue sur le tard; si je l'ai bien comprise, Vous étiez d'avis, Très-Révérend Père, qu'au lieu d'écrire toute une dissertation contre P[ère] Siwek, c'est-à-dire une critique de son premier livre, j'aurais dû parter plainte contre lui au Saint-Office.

1) C'était en premier lieu la pernicieuse influance du livre du P[ère] Siwek. Vous le savez pour sûr, Très-Révérend Père Général, qu'un livre peut être nuisible aux âmes, même quand il n'est pas contraire à la foi et aux dogmes. Nous en avons récemment un example dans le champ de l'exégèse: les auteurs qui occupent une position fidèle au surnaturel, mais qui font enfler les facteurs naturels aux prix des surnaturels, ou bien par d'autres motifs, se voient mis à l'index. Je n'affirme nullement que le livre du $\mathrm{P}$ [ère] Siwek le mérite, mais je constate en mappuyant sur une longue expérience, que son influence a été pernicieuse pour beaucoup d'âmes. Je peux en citer des preuves

${ }^{52}$ Zob. w niniejszej publikacji: J. Wołczański, Korespondencja abp. Józefa Teodorowicza z bp. Henrykiem Przeździeckim, dokument 12.

${ }^{53}$ Zob. w niniejszej publikacji: tenże, Listy abp. Józefa Teodorowicza do abp. Józefa Bilczewskiego, dokument 148. 
nombreuses et concrètes. L'explication de cette mauvaise influence ne se trouvait pas dans la position sceptique du P[ère] Siwek envers les phénomènes de Konnersreuth, mais dans ce qu'il fondait la reconnaissance des phénomènes mystiques uniquement sr des analogies psychopathiques, et négligeant les critères mystiques, il ne mettait pas en relief parmis les ressemblances, les différences fondamentales entre la psychopatie et la mystique. Cela eut pour conséquence qu'on se demanda, d'où pouvons-nous puiser la certitude, que les phénomènes mystique chez $\mathrm{S}$ [ain]te Thérèse ${ }^{54}$ n'étaient pas aussi de l'hystérie? que les stigmates de S[ain]t François ${ }^{55}$ n'étaient pas un produit de l'imagination? Après la lecture du livre du P[ère] Siwek - disaiton - on ne possède nulle ceritude quant aux vrais phénomènes mystiques. Combien de fois l'ai-je entendu! Il en résultait qu'on transportait ce scepticisme sur les miracles mêmes. Ce livre a fait des ravages, a ébranlé la foi dans beaucoup d'âmes. Je le sais indirectement et directement. Vous touchez, Très-Révérend Père Général, les souvenirs personnels et les égards au $\mathrm{P}$ [ère] Siwek. J'ai consevé ces souvenirs vivants et ils me sont toujours chers. Quant au $\mathrm{P}$ [ère] Siwek, après l'avoir connu à Cracovie avant la publication de son livre, j'avais pour lui de la sympathie. J'ai conçu le projet d'écrire une critique de son livre uniquement parce que les conséquences de ses méthodes, observées par moi directement, mont ordonné de mettre au dessus de tout l'intérêt des âmes qui s'écriaient: nous avons pensé jusqu'à présent que tel est le raisonnement du rationalisme, mais que l'Eglise a réponse à tout. Nous voyons aujourd'hui qu'un prêtre, un religieux, professeur du Gregorianum, se sert du même raisonnement au sujet des critères mystiques!

Je n'entre pas dans le meritum de ces observations, mais je pense que si le livre du $\mathrm{P}$ [ère] Siwek ne contenait que des inexactitudes, il donna lieu à un embrouillement et un désarroi des consciences, j'avais donc un motif suffisant pour prendre la parole. Et en effet la négligence des critères mystiques dans le livre du P[ère] Siwek a été quelque chose de plus qu'une inexactitude et un manque de clarté. J'ai donc cru que j'ai le devoir d'agir publiquement.

2) Le second motif de ma décision était que je ne sortais pas d'un point de vue théologique, mais généralement scientifique, touchant la méthode scientifique erronnée du $\mathrm{P}$ [ère] Siwek. J'ai posé le problème si pleinement: la mystique est une science théologique et expérimentable; chaque science se sert dans son domaine d'une science auxiliaire, mais ne se laisse pas remplacer par elle dans les conclusions définitives. J'en ai donné un exemple, puisé dans le domaine de l'histoire, qui ne se laisse pas remplacer pour fournir des conclusions définitives par l'archéologie. Mon point de vue était donc tout à fait scientifique et quiconque envisage que la mystique est une science, me rendra justice, s'il est croyant ou incroyant. C'est donc le reproche principal que j'ai fait au livre du P[ère] Siwek, en disant „u'il augmente l'importance de l'élément psychophysique, et rabaisse complètement malgré d’autres apparences, l'élément mystique” („Ateneum”

${ }_{54}$ Zob. w niniejszej publikacji: tenże, Korespondencja abp. Józefa Teodorowicza z abp. Adamem Stefanem Sapieha, dokument 29.

${ }_{55}$ Św. Franciszek z Asyżu (ok. 1181-1226), włoski zakonnik, założyciel Zakonu oo. Franciszkanów, mistyk, stygmatyk. 
1932, p. 4). Voilà les motifs pour lesquels je n'ai pas pu m'adresser au St. Office. Si je n'ai pas bien compris la lettre de S[on] Exc[ellence] l'Evêque Przeździecki, Vos paroles, Très-Révérend Père, sont la meilleure explication ou justification pour moi, car elles qualifient la lettre de Mgr Przeździecki comme „pas assez claire”, et dans un autre „passage non claire".

3) Quant à mon point de vue, que le problème, discuté par moi, se rapporte au caractère général de chaque science, donc aussi de la mystique, et comme tel est apte à une discussion scientifique, Vous l'avez indirectement prouvé, Très-Révérend Père Général, en donnant la permission au $\mathrm{P}$ [ère] Siwek de répondre à mes reproches. En lui accordant cette permission de résoudre le débat par une dicussion scientifique, Vous avez confirmé que ce débat appartient au domaine strictement scientifique.

Je doit Vous donc exprimer mon étonnement, que Vous me menacez de porter plainte au Saint-Père, c'est-à-dire que Vous transportez la question sur la voie, où décide la suprême autorité de l'Eglise.

J'apprends aussi par Votre lettre, Très-Révérend Père Général, que le P[ère] Siwek me donnera encore une réponse, ce qu'il n'a pu faire jusqu'à présent pour des motifs que je ne connais pas. Veuillez excuser si je dis que je ne comprends pas un pareil mode d'agir. Je prends pour illustration un exemple puisé dans la vie, malgré qu'il n'est pas assez précis. Les hommes décident par exemple leurs débats d'honneur d'une double manière: ils les remettent à un tribunal d'honneur, ou bien ils les confient au tribunal proprement dit. Mais qui a remis son affaire au tribunal pour les questions d'honneur, ne la confie pas après au tribunal proprement dit, en ajoutant qu'il la confiera encore en dernier lieu au premier de ces tribunaux.

Je ne puis de même comprendre le caractère de l'intrevention du Saint Père, qui devrait remplacer et aplanir ce qu'on avait mené sur la voie d'une discussion scientifique, malgré qu'on a l'intention d'y revenir en donnant le dernier mot au P[ère] Siwek. Il est pénible pour moi, Très-Révérend Père Général, que Vous prenez cette dissertation scientifique d'une manière tellement personnelle, puisque des débats pareils ont lieu parfois entre les Pères, par exemple entre Fröbes ${ }^{56}$ et Lindworski ${ }^{57}$.

Il y a eu pourtant un débat bien ardent au sujet de la question de Konnersreuth entre le professeur de l'université de Salzbourg, le Père Mager ${ }^{58}$, et le professeur d'une université

${ }^{56}$ Fröbes Joseph (1886-1947), katolicki duchowny niemiecki, święcenia kapłańskie w Zakonie oo. Jezuitów w 1900 r., studiował teologię, filozofę i psychologię, 1890-1894 nauczyciel gimnazjalny, 1889-1909 prof. filozofii w Ignatius College w Valkenburgu (Holandia), katolicki pionier psychologii eksperymentalnej, autor m.in. dzieł : Lehrbuch der experimentellen Psychologie (Bd. 1-2, Freiburg 1923-1929), Psychologia speculativa in usum scholarum (Bd. 1-2, Freiburg 1927), Compendium psychologiae experimentalis (Rom 1937, 1948²). L. Gilen, Fröbes, Joseph, w: NDB, Bd. 5, red. zbior., Berlin 1961, s. 646.

57 Lindvorski/Lindworski Johannes (1875-1939), święcenia kapłańskie w 1909 r. w Zakonie oo. Jezuitów w Holandii, profesor zwyczajny psychologii w Uniwersytecie Karola w Pradze, autor m.in. prac: Experimentelle Psychologie (1921), Psychologie der Aszese (1935). K. Frielingsdorf, Lindworski Johannes, w: DHCJ, t. 3, red. Ch. E. O’Neill, J. M. Dominguez, Madrid 2001, s. 2359.

${ }^{58}$ Zob. w niniejszej publikacji: J. Wołczański, Korespondencja abp. Józefa Teodorowicza z bp. Henrykiem Przeździeckim, dokument 10. 
suisse, le $\mathrm{P}$ [ère] Lavaud ${ }^{59}$. Dans cette discussion entrèrent des questions théologiques de premier ordre, comme par exemple celle du Christ parlant aux âmes.

Si les arguments que j'ai mentionnés ici Vous ne semblent pas assez suffisants, je rappellerai encore par surcroît que le P[ère] Siwek savait très bien que je préparais une oeuvre ample au sujet de Konnersreuth. Donc si non pour des motifs qui étaient pour moi fondamentaux et décisifs, mais par devoir d'un auteur travaillant au même sujet, j'étais obligé de discuter le livre du P[ère] Siwek, qui entrait profondément dans tous les domaines de ce problème. Ce motif seul ne me permettait pas d'éviter le débat avec le $\mathrm{P}$ [ère] Siwek. J'ai tâché de donner à cette discussion un caractère le moins bruyant, car au lieu de le faire entrer dans le livre allemand auquel je travaille, je me suis borné à la publier en articles dans „'Ateneum”.

\section{La critique et l'amour}

Vous me reprochez, Très-Révérend Père Général, que je n'ai pas suivi dans ma critique le beau précepte de S[ain]t Paul et de S[ain]t Ignace ${ }^{60}$ sur l'amour et l'indulgence, que j'était absolu et sans égards. J'y réponds par des faits. En reprochant au P[ère] Siwek Vous devez avouer qu'avec justesse - d'avoir jugé des phénomènes mystiques à l'aide de critères psychopathiques en négligeant les critères mystiques, j'ai tâché de relever tout ce qui pouvait être avantageux pour le P[ère] Siwek. Vous-même, Révérend Père, citez de mes lettres des paroles que j'ai écrites au profit de P[ère] Siwek, et qui rapportent au problème fondamental. Je répète ici quelques uns de mes textes.

En disant que le P[ère] Siwek se sert de critères psychopathiques au préjudice des critères mystiques, j'ai accentué clairement: „On doit relever une grande connaissance de la littérature psychophysiologique du P[ère] Siwek, une grande maîtrise dans ce sujet, une frappante facilité dans le maniement de problèmes scientifiques ardus, une plume légère”. („Ateneum” 1932 p. 3). Puis ensuite: „Je pense que si l'auteur, au lieu de vouloir résoudre ce problème à la lumière de la science et de la religion, s'était limité à une sphère plus modeste, et s'il avait rassemblé des matériaux scientifiques uniquement au point de vue du problème de Konnersreuth, il aurait, grâce à son érudition en matière de psychologie, rendu de véritables services dans l'étude de ce problème” („Ateneum” 1932, p. 213).

Même dans les questions les plus délicates, en affirmant que le rationalisme néglige de même, malgré que pour d'autres motifs, les ctitères mystiques, j'ai évité soigneusement de rendre le P[ère] Siwek responsable de rationalisme. J'écrivis: „Tout ceci arrive sans la conscience de l'auteur, qui est personnellement sincèrement pieux et profondément croyant. Il est un auteur de meilleure volonté, mais il appartient incontestablement à cette catégorie d'écrivains catholiques, qui s'inclinent peut-être trop exclusivement devant les méthodes expérimentales des psychologues indépendants, en puisant dans leurs oeuvres informations et méthodes” („Aten[eum]” p. 4). Le P[ère] Siwek cite luimême mes paroles, où j'affirme "qu'il se trouve au pôle opposé du rationalisme".

\footnotetext{
59 Tamże.

60 Św. Ignacy Loyola (ok. 1491-1556), hiszpański zakonnik, założyciel Zakonu oo. Jezuitów.
} 
Je pense qu'après avoir éclairé ainsi mon piont de vue, qui défend le P[ère] Siwek devant des accusations formelles de rationalisme, j'ai prouvé ma conformité à la belle maxime de S[ain]t Ignace, citée par Vous, Très-Révérend Père: „Supponendum est, Christianum unumquemque pium debere promptiora animo sententiam seu propositionem obscurum alterius in bonam trahere partem quam damnare" ${ }^{\prime 6}$.

\section{La déformation de mes thèses}

Dans la lettre que je Vous ai écrite, Très-Révérend Père Général, j’ai stigmatisé les articles du „Czas” et du „Dziennik Poznański”, dont un des Pères est l'auteur, les taxant de mensonge et d'orgueil, et j'ai prononcé, que l'oeuvre du P[ère] Siwek possède le même caractère. Vous fûtes indigné et Vous avez nommé ces accusations „injustes et infligeant un grand tort objectivement au P[ère] Siwek".

Il existe ici un malentendu. J'en appelle à Votre lettre, Très-Révérend Père, qui fut la réponse à mon reproche concret, que le $\mathrm{P}$ [ère] Siwek, en écrivant à une rédaction, m’a nommé calomniateur. En défendant le P[ère] Siwek, Vous aviez relevé la différence entre le fait de nommer quelqu'un calomniateur, et entre la définition que des paroles sont une calomnie. Je prends aujourd'hui cette différence comme réponse: je n'ai pas dit, que le P[ère] Siwek est un menteur, seulement que son livre contient des mensonges.

Si donc, Très-Révérend Père, Vous défendez le P[ère] Siwek à l'aide de cet argument, qu'il ne m'a pas offensé et ne m'a pas fait un grand tort, car il n'a pas dit certainement que je suis un calomniateur, pourquoi, mon Père, usez-Vous dans un cas analogues d'une autre mesure, quand il s'agit du P[ère] Siwek? Veuillez, Très Revérend Père Général Vous servir d'une mesure juste et égale pour juger ces deux cas tellement classiques dans la défense du P[ère] Siwek. Ensuite j’ai parlé de mensonge seulement dans ma lettre privée que je Vous ai adressée - je ne me suis pas servi de cette expression dans mon livre. Et voilà que je cite un passage de Votre lettre: „Je me permets de faire observer, que mon prédécesseur, canoniste éminent, disait avec justesse, qu'on ne doit jamais chercher une précision canonique dans des lettres privées et des conversations" - il parlait de ses lettres. „Il faut les expliquer non seulement d'aprés le contexte, mais d'après tout l'état de l'affaire". En général, Très-Révérend Père, Vous me faites le reproche le plus poignant qu'on peut me faire, d'avoir infligé un grand tort au P[ère] Siwek. Peut-on lancer un tel reproche sans le nommer et le préciser? Je suis donc obligé de demander, quelles sont les accusations qui ont fait tant de tort au P[ère] Siwek? Est-ce le reproche qu'il a jugé les phénomènes mystiques à l'aide de critères psychopatiques? Mais pourtant ses propres paroles et son livre entier le confirment?

Ou bien le reproche de ne pas connaître suffisamment les phénomènes de Konnersreuth porte-t-il un tel préjudice au P[ère] Siwek? Je l'ai prouvé en m'appuyant sur mon observation personnelle, donc j'ai confirmé la justesse de l'accusation par des faits concrets.

${ }^{61}$ Łac.: należy wysunąć wniosek, że każdy pobożny chrześcijanin powinien z ochotą zdanie lub ukryty zamiar innej osoby poczytywać raczej na jej korzyść niż potępiać. 
Porte-t-il un préjudice, le reproche, que le P[ère] Siwek a fondé ses jugements négatifs non sur des témoignages sérieux, mais sur des anonymes? Mais quiconque a lu la réponse du P[ère] Siwek peut s'en convaincre lui-même.

Je n'ai pas fait d'autres reproches au P[ère] Siwek, excepté encore un seul: celui d'avoir déformé toutes mes thèses: Je m'en occuperai spécialement ailleurs, car Vous tâchez de le repousser.

Vous n'écrivez: Ce reproche me semble aussi faire objectivement du tort au P[ère] Siwek, car on ne peut lui prouver d'avoir formellement et en conscience faussé la vérité. Pour en donner un exemple, je choisis une citation du livre de Votre Excellence: „Les phénomenes mystiques et leurs explications p. 218". Je me permets de faire observer, que des personnages bien sérieux et point trop bienveillants pour la P[ère] Siwek, ont eu l'impression, qu'un faux n'existe pas ici. Vous dites ensuite: „... qu'il peut y avoir chez le P[ère] Siwek quelques défauts de clarté, même des inexactitudes et des contradictions, ce qui peut facilement arriver dans un état d'excitation». Combien de fois le voyons-nous ici à Rome et je sais que des personnages haut placés l'affirment aussi que l'axiome des scholastiques contient une profonde vérité: „Quidquid recipitur, secundum modum recipientis recipitur"62. Il arrive donc, que des personnages sérieux qu'on ne peut soupçonner de mauvais vouloir, changent parfois ce qui leur fui dit. Toute la contradiction entre Votre défense, Très-Révérend Père Général, et mon affirmation, ressort ici avec beaucoup de clarté.

J'ai affirmé, que le P[ère] Siwek a transformé mon point de vue fondamental pour arriver à son but, et il a accompli cette métamorphose en déformant ses thèses - il est de moindre importance quel nom donnerons-nous à cette déformation: mensonge ou simple altération de mes idées de fond. Et Vous, mon Très-Révérend Père, Vous expliquez cette transformation par un malentendu, une inexactitude, peut-être même des contradictions tout à fait accidentelles, non préconçues. En face de cette explication j'en arrive à me demander, s'il est possible de nommer inexactitude accidentelle, fatigue de pensée momentanée du P[ère] Siwek, qu'il altère constamment et complétement mon attitude tant de fois et si catégoriquement accentuée, que je n'entre pas dans le meritum de la question de Konnersreuth? Est-il possible d'attribuer à un accident la façon de méconnaître aussi totalement mon fondamental point de vue et de le transformer d'une pareille manière? Est-ce possible que ce n'est qu'une inexactitude involontaire du P[ère] Siwek d'oublier mes restrictions tant de fois répétées, que je n'entre pas dans la question, si les phénomènes de Konnersreuth sont vrais ou faux, et qu'il me présente par cette métamorphose accomplie par lui, comme un défenseur acharné et non critique du miraculeux de Konnersreuth? Si le P[ère] Siwek n'a pu comprendre mes idées fondamentales, contenues dans tant d'analyses à ce sujet, que doit-on dire de sa mentalité? Et en même temps, comment expliquer que par un hasard singulier justement ces incompréhensions du P[ère] Siwek ont formé son principal plan apologétique, fondé sur la déformation de mes thèses et développé dans son ensemble et dans ses détails avec une adresse vraiment surprenante?

${ }^{62}$ Łac.: cokolwiek jest przyjmowane do czegoś, jest odbierane zgodnie ze stanem odbiorcy. 
Non, Très-Révérend Père Général, une telle défense du P[ère] Siwek est son accusation. Car ssil était vrai, qu>une pareille déformation de mes thèses, menée pour un but préconçu, n>était qu>un hasard, une inexactitude, une incompréhension de ma pensée, il faudrait supposer, que le P[ère] Siwek n'a su comprendre mes thèses du commencement jusqu'à la fin, qu'il les a toujours tournées de travers, il faudrait conclure qu'il a fait preuve de la plus grande impuissance intellectuelle. Et pourtant le P[ère] Siwek possède une grande pénétration d'esprit, une incontestable intelligence. D'autre part on devrait supposer qu'un plan préconçu et conséquent est sorti de ses incompréhensions et de ses inexactitudes.

Mais pour prouver que mon accusation du P[ère] Siwek d'avoir déformé mes thèses est injuste, Vous donnez une citation p. 218. Je le demande, que signifie une citation ou un passage en face de tout un déluge d'autres? Elle témoignerait justement, que si en ne peut trouver qu'un seul détail dans une si ample accusation, elle est bien fondée.

Du reste cet unique détail que Vous citez, Très-Révérend Père Général, malgré quil est strictement uni aux méthodes morales du P[ère] Siwek, n’a pas été placé par moi sur la liste des arguments que j'ai cité pour prouver les déformations de mes thèses par le P[ère] Siwek.

Ces déformations ont été rassemblées par moi depuis la page 42 jusqu'à la page 62 dans le chapitre intitulé: „Thèses déformées”. Je les ai suivies l'une après l'autre: extases, stigmatisation, grâces reçues gratuitement, prophéties, langues, type de Thérèse Neumann.

Je suis donc d'avis, que si des savants Vous ont dit que j'étais injuste en accusant le P[ère] Siwek d'avoir déformé mes thèses, c'étaient sûrement des savants auxquels la langue polonaise est inconnue, et qu'on leur a montré seulement le texte du P[ère] Siwek, traduit en français. Ils ont naturellement dans ce cas foi en l'auteur, qu'il cite mes véritables thèses, et ils se sont prononcés qu'ils ne voient nulle déformation. Par exemple le dr Steuer ${ }^{63}$, auquel je reviendrai encore, après avoir lu la réponse du P[ère] Siwek, écrivit là-dessus un article avantageux pour lui à la "Revue théologique" ${ }^{\text {; }}$; mais quand le consistoire de Poznań lui donna mon livre pour l'approbation, il s'orienta sur la véritable valeur de l'oeuvre du P[ère] Siwek, retira son article de la rédaction, et publia un autre dans „l'Ateneum”.

J'ajoute, que je n'en savais rien et que je l'appris ex post. Si donc ces savants avaient eu une traduction française de mon livre, comme ils l'avaient eue de celui du P[ère] Siwek, je ne peux croire qu'ils auraient absout ses déformations de mes thèses. Pourtant les preuves que j'en ai données, ne peuvent être renversées, car ce sont des citations de mon livre précédent et des paroles du P[ère] Siwek qui l'explique à sa manière ; une citation est comme un nombre dans la preuve. Comme il est facile de pénétrer au fond de la

${ }^{63}$ Steuer Albert (1874-1967), święcenia kapłańskie w 1899 r. dla archidiec. poznańskiej, dr filozofii, 1901-1919 wykładowca filozofii w Seminarium Duchownym w Poznaniu, od 1911 r. kanonik gremialny Kapituuły Katedralnej, 1946-1967 kapelan ss. Elżbietanek w Pokrzywnie k. Poznania, autor publikacji filozoficzno-teologicznych. M. Banaszak, Steuer Albert, w: SPTK, t. 7, s. 176-178.

64 „Przegląd Teologiczny” - kwartalnik naukowy wydawany we Lwowie w 1. 1920-1939; od 1931 r. pod tytułem "Collectanea Theologica”, organ Polskiego Towarzystwa Teologicznego. Redaktorzy: ks. Teofil Długosz, ks. Aleksy Klawek. 
question sans crainte de s'égarer, je Vous indiquerai seulement deux citations, chez lesquelles l'altération est visible de prime abord, et une altération de l'essence même, car de mes vues sur la critique des phénomènes surnaturels.

En écrivant sur l'hypothese du P[ère] Siwek, qu'en ne peut pas prononcer de certitude au sujet du caractère des guérisons de Thérèse Neumann, j'étais d'accord avec la thèse du P[ère] Siwek, en affirmant clairement, „qu'on ne peut rien reprocher à une solution du problème par un définitif «non constat»" 65 („Aten[eum] ” 1932, p. 8). Si le P[ère] Siwek omet ces paroles pour poser une motion contraire, et me présante comme un ennemi non critique de son "non constat”, chacun saura que penser d'une pereille méthode d'agir. Il n'ést pas besoin de se remettre ici à des commissions et à de fins connaisseurs, chacun le dira, que c'est une déformation. Et le P[ère] Siwek me suggère une thèse composée par lui; les paroles suivantes en témoignent: „Dans les méthodes dont je me sers, pour montrer la "possibilité»" - car c'est seulement de cette manière que je pose la question des guérisons par vois naturelle - le P[ère] Siwek voit un danger „sérieux”. Où est la différence avec des explications naturalistes de guérisons, par exemple à Lourdes? Et les conditions requises pour un vrai miracle, ne dépassent-elles pas Konnersreuth? („Méthodes” p. 13). La seconde déformation de mon attitude envers les phénomènes mystiques se rapporte à l'extase, aux ravissements mystiques etc. Dans cette thèse j'ai reproché sans équivoque au P[ère] Siwek le manque d'une critique scientifique suffisante, et en tout cas je l'ai exigée nécessairement pour reconnaître ces problèmes. J'ai écrit à ce sujet: „Il faut les reconnaître ou ne pas reconnaître par la voie d'une analyse scientifique et stricte, et il n'est pas permis de donner du crédit, que seule l'analyse peut rendre sûr” („Ateneum” 1932, p. 317).

Qu'a fait le P[ère] Siwek de cette thèse? En transformant complètement le caractère de ma définition du „rappel”, il ma compté et placé parmi les crédules, les non critiques, qui l'attaquent pour son criticisme et s'écrient: „L'extase de Thérèse Neumann c'est une oeuvre transcendante de la toute puissance de Dieu, c'est un miracle divin!" („Méthodes”, p. 74). Une exclamation douloureuse du P[ère] Siwek couronne cette déformation de ma thèse. Quelle douleur pour moi, quand j'ai lu la relation de ma conclusion à peu près dans cette forme: „Les extases de Thérèse ne peuvent être surnaturelles, car nous trouvons les mêmes caractères dans la pathologie” („Méthodes”, 75). Le P[ère] Siwek a appuyé sur ces deux thèses déformées mes rapports avec les phénomènes surnaturels et ma reconnaissance des miracles, tellement non scientifiques, non critiques, d'une manière si injuste pour les recherches scientifiques, que ces deux textes si déformés sont bien suffisante pour me discréditer une fois pour toutes dans le domaine de la science. C'est sur cette déformation de mes textes au sujet des miracles et des phénomènes surnaturels que le P[ère] Siwek place un puissant canon, qui doit jeter ses foudres sur moi, comme sur un homme qui voit partout du merveilleux et qui reproche de prêcher la prudence par son „non constat”. Je vois encore l'écho de ce plan dans l'article du „Dziennik Poznański”, ou l'auteur altère ma pensée par le titre seul: „Ne nous hâtons pas de reconnaître «les miracles» de Konnersreuth!"

65 Łac.: to nie jest pewne (nie stwierdza się). 
C'est le fond de son programme polémique, le secret de sa stratégie envers moi, démontrée par moi dans des dizaines de pages de mon livre. Ce travail de déformation est mené, comme je l'ai indiqué bien des fois, avec un plan d'une habileté raffinée. Cette méthode qui doit lui servir d'une part pour un éloignement de polémique sur le champ qui lui est propre, d'autre part pour m'attaquer à cause de mon attitude méritorique envers Konnersreuth, malgré que j'ai prononcé tant de fois des restrictions à ce sujet, voilà le caractère principal du travail du P[ère] Siwek. Chacun le comprendra, qu'un plan mené si systhématiquement, qui transforme du fond mes thèses, qui altère le texte de ma lettre privée, ne peut être traité comme un phénomène psychologique chez des hommes sérieux, chez lesquels la bonne volonté ne peut être mise en doute, et qui transforment parfois cemplétement ce qui leur a été dit.

Eloignez, Très-Révérend Père, les altérations du P[ère] Siwek, et sa principale idée apologétique et sa stratégie tombent en ruines. Ce que je dis ici, est clair comme le jour: Quiconque a lu la réponse que m'a donnée le P[ère] Siwek, le voit clairement, que cette réponse consiste en deux phrases.

La première exprime l'attitude du P[ère] Siwek, qu'il présente comme conforme à la science critique et à la volonté de l'Eglise. C'est une attitude qui oppose aux phénomènes surnaturels une critique scientifique stricte et serrée.

La seconde phrase présente ma position toute contraire, car je prends au P[ère] Siwek en mauvaise part son criticisme et j'exige qu'on apprécie le surnaturel des phénomènes de Konnersreuth sans critique. Dans ces deux phrases se trouve la solution de toute l'attaque stratégique du P[ère] Siwek contre moi.

Je le demande: une telle attaque est-elle possible, si mes thèses étaient fidèlement présentées? Une attaque pareille, qui est en même temps une défense, ne pourrait être imaginée, si le P[ère] Siwek voulait présenter mes thèses comme je les ai présentées. Car impossible est l'affirmation, que je prétends à une appréciatif mon critique des phénomènes surnaturels de Konnersreuth, puisque j'ai tant de fois exprimé la restriction, que je ne suis ni pour ni contre le caractère merveilleux de ces phénomènes. Il n'était donc pas possible au P[ère] Siwek de se placer sur les hauts cothurnes de la science critique en s'opposant à moi, puisque je lui ai si clairement reproché dans mon livre un dilettantisme scientifique superficiel, un manque de connaissance élémentaire des phénomènes qu'il décrit et qu'il ne connaît pas assez, enfin de n'avoir pas suffisamment approfondi le sujet et y fait entrer les critères, qui parmi les similitudes démontreront les différences.

Si donc le P[ère] Siwek a voulu mener sa principale idée polémique contre moi et arriver à la victoire, il n'avait pas d'autre choix, qu'à déformer toutes mes thèses depuis A jusqu'à Z.

Comment peut-on donc prétendre qu'il a agi inconsciemment? Combien la réponse du P[ère] Siwek est strictement liée à ce plan d'antithèse entre son scientisme et son criticisme, et le reproche que je fais à son scientisme et au manque d'une foi non critique, les articles qui prennent la défense du P[ère] Siwek, en témoignent clairement. Ils déforment ma thèse de fond, que je ne me déclare ni pour ni contre les phénomènes de Konnersreuth. Ils présentent plus ou moins le P[ère] Siwek comme une victime de 
son criticisme scientifique et font de moi un fidéiste. Tous en un mot répètent l'erreur fondamentale et centrale de la réponse du P[ère] Siwek, malgré qu'il a été par moi complètement vaincu par ses propres citations et les miennes.

Je comprends parfaitement cette attitude des défenseurs du P[ère] Siwek. Ils sont obligés de suivre la fausse voie, prise par le livre du P[ère] Siwek; s'ils l'abandonnaient, le point d'appui de sa réponse et et de sa défense serait renversé. La successive déformation de toutes mes thèses par le P[ère] Siwek avait ce seul but, car par cette déformation sa réponse se tient debout ou se renverse. Les critiques dont j'ai parlé et qui sortent de l'entourage des Pères, ne font qu'affirmer à leur manière mon opinion.

Vous comprendrez donc, Très-Révérend Père Général, que je n'accepte aucun reproche d'avoir fait du tort au P[ère] Siwek. Au contraire, je suis forcé de déclarer, que par ses méthodes, le P[ère] Siwek a fait un grand tort non seulement à moi, non seulement à la vérité, mais à la Compagnie elle-même, et en particulier à l'université, dont il est un membre. Telle est ma conviction la plus profonde.

Donc en formulant mes reproches moraux, dirigés vers le P[ère] Siwek, je pense d'après tout ceci, qu'il ne peut être question que d'inexactitudes. Quant au tort qui me fut infligé à moi, je vois d'après Votre lettre, mon Très-Révérend Père, que n>accentuant pas leessence même des torts du P[ère] Siwek par la déformation de mes thèses, Vous ne voyez pas en quoi consiste sa faute. Elle consiste en premier lieu, comme je l>ai démontré dans la question des miracles et d rautres, qu'en déformant mes citations, il me présente dans son livre comme un défenseur non critique et fanatique de Konnersreuth, et par cela même m'ôte le prestige scientifique. C'est la conséquence de son plan, peut-être non voulue. Car je le demande - qui prendra en mains le livre scientifique d'un auteur, qui s'oppose a des recherches scientifiques, qui au nom d'une croyance non critique en des guérisons miraculeuses, lutte avec la prudence scientifique de son antagoniste?

Peut-être penserez-Vous que j'exagère. J'y répond par un exemple concret. J'étais l'année dernière à Krynica ${ }^{66}$ quand parut le livre du P[ère] Siwek. Physiquement épuisé et plongé complètement dans mon travail de la vie du Christ, je n'avais nulle envie de répondre. Mais un des Evêques présents à Krynica et beaucoup de prêtres de différents côtés de la Pologne, et des plus sérieux, m’ont pressé de donner une réponse en disant que si je ne le fais pas, mon prestige scientifique s'en ressentira. Je ne m'en impressionnais encore pas trop, mais des voix commencèrent à marriver de Varsovie, que des personnes qui avaient jusqu'alors volontiers lu mes écrits, sous l'influence du livre du P[ère] Siwek s'en détournaient, comme provenant d'un auteur non critique, fanatique et naïf.

Je pourrais résigner de ce prestige scientifique quant à ma personne, s'il n'était nécessaire pour mon oeuvre de la Vie du Christ, que j'avais commencé de publier. Je me laissai donc convaincre par les faits et les persuasions - et quoique avec une répugnance intérieure - je me mis à un travail au-deesus de mes forces physiques. Si Vous,Très-Révérend Père, Vous vous apitoyez sur la santé du P[ère] Siwek, il m'est, je crois, permis de dire, que la réponse d'après la méthode choisie par lui, non conforme à la vérité et à la science objective, a bien contribué à miner ma santé, non seulement à cause d'un travail épuisant,

${ }^{66}$ Krynica - polski kurort położony w okolicy Nowego Sącza. 
mais de sentiments vraiment douloureux, car Vous admettrez qu'il était trop pénible pour moi de se frayer un chemin à travers une brousse, ou un art raffiné, remplaçait la vérité.

Cela, que le P[ère] Siwek veut m'écrire maintenant qu'il n'a pas eu l'intention de m'offenser, n'est pas une réparation du tort qu'il m'a fait.

\section{Le ton de mon livre}

Vous caractérisez le ton de mon livre, Très-Révérend Père Général, „comme une mordante ironie, un amer sarcasme, des comparaisons satiriques.

Je dois accentuer, Très-Révérend Père, que ce serait un grand tort pour mon travail, si Vous vouliez le considérer seulement comme une critique ironique de celui du P[ère] Siwek. Qui a lu attentivement mon livre sait parfaitement, que d'après mes faibles forces j'ai donné sur ces environ quatre cent pages la solution de tous les problèmes de Konnersreuth avec une exclusive objectivité, dans laquelle le travail du P[ère] Siwek disparait presque complètement. Voilà pourquoi on a tellement insisté en Allemagne sur la traduction de ce livre. La polémique avec le P[ère] Siwek y intéressait peu, mais la critique scientifique des phénomènes de Konnersreuth était pour les Allemands d'un grand intérêt. Si Vous parlez d'ironie, Très-Révérend Père Général, veuillez relire ces passages où on trouvera les remarques que Vous nommez ironiques. Vous vous convaincrez que sur une étendue d'environ 400 pages, ces quelques remarques ne sont pour la plupart qu'une réponse aux ironies du P[ère] Siwek.

Si je le demande, comment peut-on discuter avec l'ironie sérieusement, comment la traiter, si on n'est par une remarque ironique?

J'userai ici d'une phrase empruntée à l'Ecriture Sainte, en soulignant la restriction, que je me sers de ses paroles seulement dans le sens général, ne rapportant nullement au P[ère] Siwek la définition: sot. Voici cette citation: „Donnez réponse au sot d'après sa sottise". Je n'applique cette citation au P[ère] Siwek que dans ce sens, qu'au mode d'ironie cynique de ses attaques, je ne puis répondre que d'une manière qui leur est adaptée.

Si Vous aviez le temps de parcourir attentivement ces passages de mon livre, qui à parler strictement ne sont même pas ironiques, Vous pourrez Vous convaincre que ces passages d`exception ne sont qu>une réponse aux ironies du P[ère] Siwek. Pour ne pas alourdir le texte, je cite en supplément quelques allusions ironiques, tournées vers moi, et voisinant presque avec le cynisme.

Je pense que la meilleure illustration de mes paroles seront les citations, dont je donne quelques unes en exemple. Voici qu'écrit le P[ère] Siwek: „Nul ne peut fonder sur une pure possibilité". Il est possible, que quand je serai dans la rue, une tuile me tombera sur la tête et me tuera. Mais si à cause de cette „possibilité” quelqu'un se verrouillerait dans sa maison et ne voudrait pas en sortir pendant toute sa vie, un chacun dira: il est temps de l'enfermer dans une maison de santé („Méthodes” p. 86).

„Elle ne montre pourtant d'autres stigmates à personne” („Ateneum” février 1932, p. 112). Je réponds: „Il ne manquerait qu'elle montre ceux de son côté! Elle s'exposerait alors à un nouveau reproche: « d'immoralite »" (Méthodes” p. 86). 
„Ne sont-ce pas ceux qui déforment plutôt l'image de Thérèse Neumann qui ex post proclament le « surnaturel » de ses visions, font soigneusement des retouches à son portrait moral et physique, le libérant de chaque tache, avouant seulement in ordine logico ${ }^{67}$, qu'elle a des faiblesses, des défauts, et les adaptent à ses dons spirituels?" (Ibid[em] p. 98).

„Nous avons été tous une fois malades. Mais nous n'avons pas eu tous des accès de colère contre le médecin et sa diagnose. Nous ne nous sommes pas nous vengés sur lui après son départ! nous ne nous sommes pas tous moqués de lui! ... Nous ne sommes pas tous insupportables pendant la maladie. Nous n'avons pas tous tramé des plans de fuite de l'hôpital ... des simples garde-malades savent discerner parmi les malades les personnes «nerveuses », dans notre langage: «émotives »- de celles qui ne le sont pas. Elle n'attribuent pas la «nervosité » à tous les malades" (Ibid[em] p. 67).

Et encore; „Il n'y a pas de dogme de foi, duquel en le référant ainsi, on pourrait le changer en une formelle hérésie. Pierre dit par exemple: Dieu n'a pu créer le monde par nécessité - c'est un dogme! Paul, citant les paroles de Pierre, s'exclame: Dieu n'a pu créer le monde! - hérésie!" (Ibid[em] p. 75).

Ajoutez-y, Très-Révérend Père, ces reproches, que je n'ai point d'idée de ce que la doctrine de l'Eglise parle des prophéties et vous verrez comme est indulgente la défence du P[ère] Siwek dans Vos paroles: „Peut-être qu'une parole un peu tranchante lui est échappée, mais une chose pareille arrive facilement dans une discussion”.

Ici se trouve aussi une réponse à Votre avis, que „les chances sont inégales dans une discussion entre moi et lui, car je me trouve dans des conditions bien meilleures que le $\mathrm{P}$ [ère] Siwek. Si on lui permettait d'écrire, il ne pourrait le faire aussi franchement que Votre Excellence à cause de votre dignité épiscopale".

Peut-on prétendre après la lecture de ces citations que le P[ère] Siwek était entravé par des égards envers moi? pouvait-il faire plus de remarques ironiques et cyniques à quelqu'un, qu'il ne m'en fait à moi dans sa réponse?

Suit après tout un cortége de passages scientifiquement non fondés, ou le P[ère] Siwek cite l'un après l'autre des noms latins empruntés à la logique, pour se démontrer que je ne pense pas logiquement et que je répète continuellement des erreurs de logique. Ces reproches sont posés dans une forme qui parle pour elle-même.

Quand l'abbé Bogdanowicz ${ }^{68}$ dans ses articles publiés dans la "Gazeta Kościelna” 99 (Gazette écclésiastique) - je n'entre pas dans leur meritum se servit littéralement envers le P[ère] Siwek de la même méthode, dont ce dernier avait usé envers moi, et commença a lui démontrer ses défauts de logique, cela suffit pour provoquer chez Vous, Très-Révérend Père Général, la plus grande indignation. Si on est si sensible et si impressionable à des méthodes de ce genre, mais fondées, que dire de cette méthode appliquée envers moi, et dont le manque de fondement a été démontré dans mon livre. Ajoutez-y ce jeu et ce délice à maccuser d'un manque de connaissance élémentaire des principes de la foi

\footnotetext{
${ }^{67}$ Lac.: w porządku logicznym.

${ }^{68}$ Zob. w niniejszej publikacji: J. Wołczański, Listy abp. Józefa Teodorowicza do abp. Józefa Bilczewskiego, dokument 141 .

${ }_{69}$ A. Bogdanowicz, O logikę w mistyce, GK, 41(1934), nr 8, s. 80-82; nr 12, s. 132-134.
} 
et de la mystique, de même sans fondement, Vous comprendrez alors, Très-Révérend Père, que mes allusions peu nombreuses n'étaient qu'une simple et nécessaire conséquence des attaques ironiques et cyniques du P[ère] Siwek contre moi.

Je le répète: conséquence nécessaire, car de telles attaques dans une réponse ne peuvent être traitées sérieusement; la méthode unique d'y répondre est justement celle que j'ai choisie. C'est pourquoi je vois une complète partialité dans ce problème si Vous voyez seulement les conséquences d'une méthode, appliquée par le P[ère] Siwek, et Vous couvrez l'auteur comme s'il était innocent, et n'avait pas provoqué dans mon livre ces passages qui Vous scandalisent, Très-Révérend Père Général, et que Vous essayez de transporter dans tout le caractère de ma discussion, tranquille et objective, sur le problème fondamental de la stigmatisation.

\section{La réclame}

Quand à la réclame, Vous m'écrivez: „... dans des journaux de toutes les nuances, politiques, scientifiques, populaires - dans des revues mensuelles, hebdomadaires, on présente le P[ère] Siwek de la plus défavorable manière quant à sa valeur morale et intellectuelle, pour le détruire - je ne trouve pas d'autre expression - dans l'opinion publique".

En premier lieu, je dois accentuer que je n'ai nullement influence les recensions que Vous mentionez, Très-Révérend Père; je ne savais même pas qu>elles devaient paraître. La seule exception était lıarticle de lıabbé Bogdanowicz, duquel jeétais informé, mais je le souligne, que je n'ai influencé ni son idée, ni son exécution. D’après Votre lettre, Très-Révérend Père Général, il y a eu une foule do critiques, dirigées contre le P[ère] Siwek et voulant complètement l'anéantir. Il suffit de faire un registre de ces critiques pour se convaincre comme il y en a peu; pour les compter, il suffit des doigts d'une seule main.

Je ne compte pas ici la critique qui n'est pas une réponse pour le P[ère] Siwek, mais pour son recenseur, signé des lettres J. N. ${ }^{70}$ Malgré qu'il est déjà connu, qui se cache sous, ce pseudonyme, ce n'est que la manière inouïe de défense du P[ère] Siwek qui a donné lieu à des articles contraires. Quant à d'autres journaux, il est tout naturel qu'après la publication de mon livre, chaque journal s'est cru obligé d'en donner un compte-rendu, un livre d'environ 400 pages, dont l'auteur est un Evêque, et qui s'occuppe d'un problème strictement scientifique, très actuel au point de vue de la mystique, de la psychopathie etc.

Ce n'est que le „Przegląd Powszechny” (Revue universelle) qui se permet le luxe de vouloir tuer un livre par son silence, comme par exemple mon livre de la Vie de Jésus-Christ „De Bethléem à Nazareth"71, l'oeuvre de toute ma vie, de laquelle pendant deux ans cette revue n'a fait aucune mention, malgré qu'elle en donne des amples au sujet de chaque petit livre de dévotion. Tous les journaux considèrent comme leur devoir d'écrire une telle critique, mais qui voudra les lire, ne dira jamais qu'elles tendent à anéantir le P[ère] Siwek. Parcourons les l'une après l'autre.

${ }^{70}$ Kryptonim niezidentyfikowany.

${ }^{71}$ J. Teodorowicz, Jezus Chrystus, t. 2: Od Betlejem do Nazaretu, Poznań 1932. 
Il y a eu une critique dans „l'Ateneum”, de la plume de l'abbé professeur Steuer, qui était pourtant indispensable dans cette Revue qui avait publié mes articles; chacun le comprendra. Il y en a eu une dans le „Przegląd Katolicki” (Revue catholique), écrite par M. Czarnecki ${ }^{72}$, mais il y a eu aussi du même auteur une critique sympathique du livre du P[ère] Siwek. L'auteur a signé du nom de: Roicki ${ }^{73}$. Dans la revue „Szkoła Chrystusowa" (L'école du Christ) fut publiée une critique de mon livre par le Dominicain le Père $\mathrm{Fic}^{74}$, aussi après celle du livre du P[ère] Siwek, de même sympathique. Il y a eu encore dans le „Kurier Warszawski”75 une critique assez délicate et réservée, signée du pseudonyme „Szary”. Voilà tout. Les articles écrits par l'abbé Bogdanowicz dans „Gazeta Kościelna” étaient plutôt à publier dans une revue mensuelle,ne s'occuppent à vrai dire pas tant de mon livre, ni ne sont directement une critique de celui du P[ère] Siwek, mais présentent une étude de son livre du point de vue de la logique, analogiquement à son travail me concernant, comme je l'ai déjà indiqué à une autre place.

Où est donc cette foule de revues mensuelles, hebdomadaires, de quotidiens de toutes nuances, que Vous mentionnez, mon Très-Revérend Père? Et quelle différence entre elles et celles du côté opposé! Premièrement par leur nombre. Combien y en a-t-il eu dans le "Ilustrowany Kurier Codzienny"76 (Courrier quotidien illustré), journal extrêmement répandu, donc ces articles ne sont en aucun rapport avec ceux qui sont contenus dans des revues, lues seulement par certaine cercles, et quel autre est leur caractère! Les critiques du camp du P[ère] Siwek, en rapports directs avec les Pères, au lieu de présenter fidèlement mes pensées, les changent et les faussent toutes, me font voir, comme je l'ai déjà dit autre part, non moralement, mais intellectuellement sous le plus mauvais jour. Mais quand on jette un coup d'oeil sur les autres critiques de mon livre, on voit qu'elles le présentent tout objectivement comme ce qu'il est, en n'exprimant même pas leur opinion personnelle, ils donnent le résumé du livre. Les critiques du P[ère] Siwek frappent et attaquent en dessous, car ils ne lèvent pas leur visière et se cachent sous un pseudonyme, tandis que ceux de mon livre signent franchement leur nom. Chez les premiers il n'y a qu'une signature, celle du Père Szczepański ${ }^{77}$, qui en résumant le livre du P[ère] Siwek a répandu non seulement en Pologne, mais dans toutes les parties du monde la conviction de „la fin de la légende Konnersreuth”, et m'attaquait en parlant de ma défaite.

Veuillez donc, Très-Révérend Père Général, faire le bilan de ces deux camps de critiques et Vous verrez que ce que Vous m'avez écrit n'existe pas en réalité. Ce n'est pas le $\mathrm{P}$ [ère] Siwek, mais moi qui fut partout frappé avec le concours direct ou indirect des Pères.

72 Osoba niezidentyfikowana.

${ }^{73}$ Osoba niezidentyfikowana.

${ }^{74}$ Zob. w niniejszej publikacji: J. Wołczański, Korespondencja abp. Józefa Teodorowicza z prof. Stefanem Dabrowskim, dokument 9.

75 „Kurier Warszawski” - dziennik wychodzący w 1. 1821-1939 w Warszawie, związany ze Stronnictwem Chrześcijańsko-Narodowym.

${ }^{76}$ Zob. w niniejszej publikacji: J. Wołczański, Korespondencja abp. Józefa Teodorowicza z abp. Adamem Stefanem Sapieha, dokument 104.

77 Osoba niezidentyfikowana. 
Comme il maccable, le critique appartenant à Votre Congrégation, dans le "Czas" et le „Dziennik Poznański”, et parle avec mépris des critiques de mon livre et nous relègue au camp des hommes, qui ne sont pas en état d'apprécier les grandes lumières d'un professeur du Gregorianum et auxquels va luire la splendide clarté de la nouvelle Encyclique du Saint Père sur la science chrétienne! Combien y a-t-il chez cet auteur de mépris dédaigneux, presque, qui arrive jusqu'à piquer exprès un critique dans le titre même. Par exemple le Père Fic, Dominicain, est un savant qui fut agrégé à l'université de Cracovie, a fini la théologie à Louvain. Pour montrer son dédain et souligner que le P[ère] Fic est entré dans un domaine qu'il ne connaît pas, cet auteur déclare qu'il n'est qu'un "géographe".

Et maintenant je me permets de demander, qui a été la cause de critiques défavorables pour le P[ère] Siwek? N'est-ce pas lui-même en première ligne? Il a pourtant par son premier livre induit en erreur ces savants qui lui ont donné crédit, et les critiques défvorables de son livre en sont une réaction. Il en fut ainsi avec la critique de M. Czarnecki, qui s'était senti compromis par ses premiers éloges pour le P[ère] Siwek; il en était de même avec la critique d'un savant de tel renom que le professeur Steuer.

Je le demande: à qui la faute, si le second livre du P[ère] Siwek, c'est à dire la réponse qu'il ma donnée, entra dans le forum public et devint l'objet de critiques publiques? Personne d'autre que le P[ère] Siwek et les Pères en particulier, car il est d'usage dans le monde littéraire qu'on répond dans le même journal où la critique était publiée. La critique du livre du P[ère] Siwek le fut dans „l'Ateneum”. La loyale courtoisie envers moi exigeait une réponse dans le même "Ateneum, surtout dans un cas si nouveau que la polémique entre un Evêque et un religieux. Mais voilà que pour un motif aussi futil, que "'Ateneum" ne voulait pas envoyer les épreuves à Rome, le P[ère] Siwek jeta son livre sur les ondes d'une discussion publique. S'il avait du moins publié sa réponse comme manuscrit, on aurait évité les recensions publiques!

Les Pères de Cracovie ont senti parfaitement l'inconvenance de la publication d'un pareil livre; ils comprenaient, que la polémique d'un religieux avec un Evêque qu'il traite d'une façon inouïe, ne pourra que scandaliser l'opinion, son préparée scientifiquement à un tel travail. Malheureusement, un ordre arriva de Rome de publier ce livre, contrairement à l'opinion des Pères de Cracovie!

Vous mentionnez, Très-Révérend Père, le passage de ma lettre à Son Eminence le Primat, où je lui écris que jrai des prouves fulgurantes contre le P[ère] Siwek. Je les ai en effet. Mais Vous me dites que je veux l'anéantir. Ce reproche n'est pas juste, car puisque je ne me suis pas servi de ces preuves dans mon livre, que j'ai préféré, au lieu de le frapper à l'aide de ces documents que je possède, suivre un chemin long et fatigant pour moi, cela indique clairement jusqu'à quel point j'ai épargné le P[ère] Siwek. Naturellement qu'en présence de Votre annonce, Très-Révérend Père Général, et de celle d'un travail futur du P[ère] Siwek, nul ne peut exiger que je ne fasse pas usage de ces documents pour ma propre défense. Vous me dites que l'abbé Bogdanowicz a écrit ses articles en vue d'une réclame pour soi.

L'abbé Bogdanowicz avait déjà en septembre une réponse prête au P[ère] Siwek, mais il ne la publiait pas, comptant que je désire conclure cette affaire d'une manière la plus 
paisible et d'éviter tout ce qui pourrait être irritant de ma part pour la critique future. Je relève avec éloge cette abstinence de l'abbé Bogdanowicz, car elle n'a pas été provoquée par mes ordres, mais par son propre sentiment. Malheureusement, de même que la polémiqué publique a été la conséquence de la réponse du P[ère] Siwek remise aux librairies, les articles des Pères l'ont éveillée dans les cercles qui me sont proches. Si du moins ces articles étaient critiques, scientifiques! Non dans des sérieuses revues, mais dans des journaux quotidiens furent publiées ces insipides réclames pour le P[ère] Siwek et son travail, avec des allusions offensantes pour ceux qui oseraient les critiquer, et d'autres masquées pour moi, qui suis un chercheur non critique de l'élément miraculeux dans les phénomènes. Il faut donc le dire, que les articles de l'abbé Bogdanowicz furent écrits exprès dans le même ton qu'avait l'attaque dirigée envers moi, pour en finir une fois pour toutes avec de pareilles méthodes combatives de polémique. Je n'ai pas l'intention d'entrer dans le meritum des articles de l'abbé Bogdanowicz, mais j'annonce que l'archive de Konnersreuth est ouverte à mes chanoines et que l'abbé a publié son travail sous sa propre responsabilité.

Encore une remarque. Avant de publier mon livre, j'en donnai le manuscrit à trois personnes possédant beaucoup de tact dans de pareilles questions. Je priai chacune d'elles de prendre connaissance du manuscrit et de morienter sur les passages qui auraient un caractère personnel envers le P[ère] Siwek. C'est la meilleure preuve que je ne voulais pas le froisser et le payer avec la monnaie dont il s'était servi.

Chacun a sa manière de polémiser, la mienne est toujours vive et directe, mais je dois dire, que si vous trouvez, Très-Révérend Père, que le ton de ma polémique est tranchant, j'indique la méthode du P[ère] Siwek pour l'expliquer, de même que la manière dont il s'est servie dans son second livre envers Thérèse Neumann. Avant la publication de ma critique dans "l'Ateneum”, quand le P[ère] Siwek ignorait encore ce que j'ecrirai, il a osé dans une lettre qu'il m'adressa après mes conférences à Cracovie, railler Thérèse Neumann de même que moi-même. Il nomme Thérèse dans cette lettre une fillette, il me fait des allusions de modernisme etc. Mais ce qui est le plue important, il m'annonce dans une de ces lettres dans quelle direction ira sa critique éventuelle, si j'ose critiquer son travail. „Je serai obligé de toucher à toute une série de points délicats, plus ou moins personnels, de ceux qui sont mêlés à la question de Konnersreuth". Malgré qu'on pourrait juger que ces paroles ont un caractère général, unis à d'autres détails, ils font voir clairement que le P[ère] Siwek me menace, en cas que j'entrerais en discussion avec lui, de se venger sur Thérèse Neumann en transportant le débat sur des questions personnelles à son sujet. Je me suis peut-être servi d'un mot trop drastique: se venger. Mais il m'est difficile de définir autrement la liaison entre la menace du P[ère] Siwek et mon travail éventuel qu'il ne connaissait pas, vu qu'il n'était pas encore publié.

Le P[ère] Siwek a tenu son annonce. Il commet au plus haut degré une indiscrétion en publiant les révélations du Consistoire de Regensburg, par surcroît, comme le dit la lettre de S[on] E[xcellence] l'Evêque Buchberger ${ }^{78}$, non vraies. Il relève une série de

\footnotetext{
${ }^{78}$ Zob. w niniejszej publikacji: J. Wołczański, Korespondencja abp. Józefa Teodorowicza z prof. Stefanem Dąbrowskim, dokument 32.
} 
faits qui compromettent Thérèse Neumann, fondées sur des anonymes, de même non véritables, et il y ajoute de sa part des passages qui frappent par leurs soi-disants et leur piquanterie avec une malice ironique les côtés les plus délicats du caractère de Thérese Neumann, car son moral.

Je laisse à Votre jugement, Très-Révérend Père Général, si une telle manière d'attaquer une pauvre personne sans défense, s'appuyant sur des anonymes et voulant ignorer les témoins oculaires comme Mgr. l'Evêque Lisowski ${ }^{79}$ et moi et les documents écrits, est conforme avec Votre jugement "qu'on ne peut uniquement attribuer au P[ère] Siwek qu'un bon vouloir".

Pour moi, une pareille manière d'agir et de critiquer est incompatible avec la bonne volonté. Une méthode pareille parle pour elle-même et doit provoquer chez ceux qui sont même indifférents à la question de Thérèse Neumann non seulement un dégoût, mais de l'indignation. Cet éclaboussement de Thérèse avec de la boue m'indigne aussi à cause de ce que juste à présent les Evêques de Bavière ont confié cette question à S[on] $\mathrm{E}$ [xcellence] l'Evêque Buchberger qui s'en occupe. D'après les paroles que j'ai entendues de sa bouche au cours d'une conversation avec lui, je le sais quelle haute idée il a du caractère moral de Thérèse Neumann, ce qu'il a prononcé publiquement pendant ses sermons.

Donc l'action de jeter Thérèse Neumann avec tant de cynisme en pâture au protestantisme et au rationalisme, comme l`a fait le P[ère] Siwek doit forcément provoquer do l'indignation. Si je rassemble donc tous les points de Votre défense du P[ère] Siwek, je suis forcé d'affirmer avec peine, que je n'ai pu en trouver un seul de juste, malgré que j'étais prêt à le faire. Mais il est naturel que ce sont les plus faibles défenses, celles qui veulent tout expliquer et tout défendre.

Votre coeur, et comme on le dit, paternellement faible et indulgent pour le P[ère] Siwek, Très-Révérend Père Général, a voulu effacer chaque trace de tache chez son fils spirituel, car même là, où Vous avouez quelque point, Vous le voilez et le défendez en même temps.

Donc si le P[ère] Siwek m'a attaqué du haut de sa chaire avec moquerie, Vous le défendez en prétendant que cela n'offense personne si on dit que quelqu'un n'est pas fort dans un domaine étranger pour lui. Voilà que la pointe du tort du P[ère] Siwek est émoussée, et pourtant il m'avait raillé que je m'occupe de choses que je ne comprends pas. Quelle impressionabilité chez Vous, Très-Révérend Père, pour la critique actuelle du $\mathrm{P}$ [ère] Siwek qui frappe son prestige intellectuel, et quel manque d'impressionabilité non même pour une critique objective, mais pour des railleries de ma mentalité à moi.

Les attaques du P[ère] Siwek, ironiques, cyniques, violentes, ce n'est qu'une excitation nerveuse. Il ne Vous est même pas connu, ce ton violent des attaques du P[ère] Siwek, si bien connu des rédactions auxquelles il a eu contact; l'une d'elles m'a même averti du manque d'égards qu'il montre pour ses adversaires. Son ironie et le cynisme qui se montre dans les pages de son travail ne sont pas visibles pour Vous et ne sont qu'une chose minime, une parole un peu fortement prononcée!

${ }^{79}$ Zob. w niniejszej publikacji: tenże, Korespondencja abp. Józefa Teodorowicza z abp. Adamem Stefanem Sapieha, dokument 77. 
Son habile déformation de toutes mes thèses, ce n'est qu'une subjective inadvertance. Si on lutte avec le P[ère] Siwek à l'aide de ses arguments, on péche par manque d'amour, car seul celui qui comprend tout, sait tout pardonner. Polémiser avec lui, répondre à ses reproches, c'est lui infliger du tort etc. etc.

Excusez, Très-Révérend Père Général, que je fais ainsi le bilan définitif du caractere de toute la défense et que je suis forcé de la trouver insuffisante. J'ai un plein respect pour le sentiment que Voue avez pour le P[ère] Siwek, mais j'étais obligé d'indiquer tout ce qui est voilé et caché à l'aide de ce sentiment.

\section{Conclusions}

J'aborde maintenant la conclusion définitive. Vous m'avez suggéré par l'intermédiaire de Son Eminence le Primat la pensée d'une publique déclaration de ma part. J'ai répondu au Cardinal que je trouve ce projet très difficile à réaliser et j'ai émis les motifs de mon refus. En général et en principe je suis d'avis que là où on décide une question par la voie d'une discussion publique, il n'y a plus de place pour une déclaration. Mais malgré le scepticisme avec lequel je considérais cette question, j'aurais voulu acquiescer à Votre désir. Car à la fin, ce qui est difficile, n'est pas encore impossible. Il est certainement difficile d'imaginer des raisons d'une déclaration de ma part, disons demi officielle. Elle pourrait éveiller l'impression que je me rétracte. Peut-être que par un échange de lettres, dont la première serait celle du P[ère] Siwek, pourrais-je dans ma réponse rappeler tous les passages de mon oeuvre où j'ai parlé de lui favorablement. Après avoir présenté au Primat mes difficultés, j'ai remis entre ses mains la solution définitive de cette affaire. J'attendais même quaprès une entente du Primat avec Vous à Rome et l'examen de mes difficultés le projet arrivera à des formes concrètes. Mais voilà qu'au lieu d'une réponse du Primat, je reçois une lettre de Vous, Très-Révérend Père Général, par laquelle je suppose que Vous ne comptez plus sur l'intermédiaire de Son Eminence et sur ma déclaration que je lui ai donnée; mais que Vous prenez Vous même l'affaire directement en mains en me dictant des conditions.

J'avoue que ce mode d'agir ma grandement étonné. Je pense que par égard à la personne du Primat et à la mienne, on ne peut nommer ce tour de l'affaire ni désirable ni même convenable. Puisque j'ai montré ma bonne volonté, j'ai parlé dans cet esprit avec le Métropolite Sapieha ${ }^{80}$ et le Métropolite Szeptycki ${ }^{81}$, j'avais droit au respect dû à mon attitude et à ma dignité. Mais je mets de côté ce détail. A côté de la disposition de mon éventuelle déclaration, qui voudrait que je nomme les méthodes du P[ère] Siwek bonnes, malgré que je les ai combattues d'un point de vue strictement scientifique, il se trouve dans Votre projet une condition des plus importantes. Vous déclarez, Très-Révérend Père, que n'ayant pas abouti à recevoir de ma part les explications nécessaires, Vous vous

${ }^{80}$ Zob. w niniejszej publikacji: J. Wołczański, Listy abp. Józefa Teodorowicza do abp. Józefa Bilczewskiego, dokument 2 .

81 Tamże, dokument 3. 
adresserez avec cette affaire directement au Saint-Père. Je dois dire, qu'une pareille déclaration de Votre part met fin à ce que je sois prêt à mener cette affaire d'après Vos désirs.

Car agissant en quoi que ce soit sous une pareille menace, j'attirerais les apparences d'avouer que mes livres contiennent quelque chose qui a pu fournir des matériaux pour une accusation tellement inouie. Je ne peux en assumer même une ombre.

Puisque Vous avez posé ainsi la question, Très-Révérend Père Général, je Vous déclare loyalement, qu'éventuellement moi aussi je porterai plainte à La Sainteté sur le $P$ [ère] Siwek. Cette plainte se rapportera principalement à son attaque contre moi, proférée à Rome du haut de sa chaire, et qui n'est pas si simple comme Vous le prétendez. Car le P[ère] Siwek s'est raillé de moi en présence des étudiants. Il ne s'agit pas de cela si la chose s'est plus ou moins répandue, il s'agit du caractère de cette action, et si les prêtres revenant de Rome et les religieuses romaines me l'ont fait connaître, je ne rends pas ce fait plus éclatant, comme Vous le pensez.

Ensuite je me plaindrai que le P[ère] Siwek dans sa réponse relativement aux prophéties m'a fait un reproche public d'une doctrine non conforme à celle de l'Eglise. Car en faisant dépendre la vérité des prophéties de l'existence des extases, ce que le P[ère] Siwek me suggère, c'est une erreur de doctrine dans une question aussi fondamentale et primordiale comme l'est la doctrine des prophéties. Je donnerai aussi à Sa Sainteté des preuves que le P[ère] Siwek má moralement abaissé en faisant de moi un fidéiste crédule et non critique.

Je peux Vous donner la déclaration que j'ai donnée à l'Archevêque de Cracovie bien longtemps avant Votre projet.

J'exprime cette déclaration sans égard pour Vos démarches éventuelles, car elle ne présente rien de nouveau, elle répéta seulement mes déclarations antérieures. J'ai déclaré au Métropolite de Cracovie, que si les Pères ne lutteront pas avec moi publiquement, je ne toucherai plus la question des débats avec le P[ère] Siwek dans ces limites et avec les restrictions que j'ai exposées dans ma lettre à Son Eminence le Primat. Je ne peux être responsable des critiques qui apparaitraient en dehors de moi, mais je pense qu'elles sont presque finies. S'il s'agit de moi, je ne toucherai plus cette question sous aucuns forme. Je pense que c'est fondamental et essentiel.

Je remets donc le destin d'une discussion ultérieure entre les mains des Pères. Il dépend d'eux complètement si l'affaire s'apaise, ou si - ce que je ne suppose et ne désire fortement pas - elle s'irrite de nouveau.

Permettez moi encore une remarque qui finit cette lettre. Vous mavez fait observer, Très-Révérend Père Général, que c'est dommage de sacrifier tant de temps aux choses qui ont la cause de ce débat. Je Vous ne prends pas en mauvaise part cette admonition, d'autant plus qu'il y a longtemps que je me la suis faite à moi-même. Mais je pourrais peut-être une fois Vous révéler verbalement, comme j'ai été poussé même contre mon vouloir à m'occuper du problème de Konnersreuth, et le débat fondamental avec le $\mathrm{P}$ [ère] Siwek en a été la conséquence nécessaire. Mais je me vois forcé à faire une observation à Votre adresse, Très-Révérend Père Général, et je suis convaicu que Vous ne la prendrez pas en mauvaise part. 
La question de Konnersreuth est un problème qui ébranle le monde, et comme le P[ère] Siwek l'a dit dans son premier livre, il possède tout ce qui peut en ébranler les bases. Naturellement qu'il s'agit, si ce problème est une illusion ou s'il est véritable. Ces questions doivent être décidées par la science, ensuite par l'Eglise en définitif. Mais quelle doit être l'attitude de la critique envers ce problème? Peut-on nommer sérieuse et objective celle qui fut exprimée par le dernier travail du P[ère] Siwek? Il est sorti à la rencontre de ce problème en premier lieu avec une étonnante ignorance des faits de Konnersreuth, en les jugeant avec présomption et les connaissant trop peu. Il s'approcha de ce problème avec une prévention qui arrive au cynisme quant à la personne de la stigmatisée. Il a raillé ce problème d'une manière quaucun rationaliste n'a osée. En jugeant ce problème, il a écarté les plus authentiques témoignages de témoins oculaires, en s'appuyant seulement sur des anonymes.

Il n'est pas étonnant si un tel livre devient dans les mains des protestants et des rationalistes un évangile pour combattre le caractère surnaturel de phénomènes dans l'Eglise et cela à un moment, où ces phénomènes sont l'objet d'un examen de l'Eglise. Si un tel problème est le signe de l'action du Saint-Esprit, dans le cas la possibilité seule de cette action une pareille attitude est coupable, non seulement du point de vue d'une objectivité des recherches scientifiques, mais de celui d'une position ennemie à l'éventuelle action de l'Esprit-Saint dans le monde et de ses décisions qu'il veut provoquer par ces phénomènes.

Il ne s'agit plus ici si ce quelqu'un qui se pose en ennemi du problème s'appelle P[ère] Siwek et est professeur au Gregorianum, ou s'il se nomme Teodorowicz et est un Evêque! Ce sont des questions personnelles qui disparaissent complètement devant le phénomène de ce problème. Il s'agit ici qu'en face de l'éventualité d'une action de l'Esprit-Saint, une pareille opposition d'avance à cette éventualité pèse lourdement non seulement sur le chercheur, mais sur sa Congrégation, si elle ne voit pas sa faute, mais le défend encore jusqu'au bout.

J'en ai dit assez, peut-être trop. Pardonnez-moi, mais je crains et je tremble pour Votre responsabilité dans cette question, Très-Révérend Père Général.

Je citerai ici le Père Mager, que le P[ère] Siwek présente comme tête des ennemis de Konnersreuth. Il ne l'est nullement et je l'ai démontré dans mon travail; je possède une lettre du P[ère] Mager qui approuve complètement l'attitude que j'occupe envers lui dans mon livre.

Le P[ère] Mager a eu le noble courage de publier dans le „Benediktiner Bote” la lettre d'une grande dame allemande catholique, qui lui raconte avec détails la miraculeuse conversion de son mari, un protestant, au catholicisme, et exprime au P[ère] Mager et à l'abbé Wunderle ${ }^{82}$ son regret qu'en présence de signes divins si évidents ils conservent leur attitude défavorable envers Konnersreuth. Dans la préface qu'il donne à cette lettre, le P[ère] Mager explique, que son attitude est quelquefois mal comprise, mais en

${ }^{82}$ Wunderle Georg (1881-1950) - niemiecki duchowny, prof. teologii i filozofii, wykładowca na Uniwersytecie w Eichstätt i Würzburgu. Prowadził badania w dziedzinie filozofii religii, psychologii religii, historii religii, pedagogiki i in.; autor m.in. pracy: Die Stigmatisierte von Konnersreth (1927). J. Hasenfuss, Wunderle Georg, w: LThK, Bd. 10, herausg. von H. Höfer, K. Rahner, Freiburg im Breisgau 1965, s. 1265-1266. 
publiant la lettre reçue, il donne de la force aux arguments dont cette dame s'est servie contre lui, en parlant de la responsabilité qu'assume devant Dieu celui qui occupe envers ce problème une attitude conforme ou non conforme aux principes d'une saine critique. Ce noble maintien du P[ère] Mager qui n'a pas hésité à jeter son propre prestige pour s'incliner devant l'éloquence de conversions extraordinaires, m’a incité à Vous faire, Très-Révérend Père Général, cette remarque, appuyée par l'opinion d'un des Princes de notre Eglise, qui personnellement Vous est très-dévoué.

Je finis ma lettre par ces paroles.

Lwów, 14 V 1934

J'y joins encore une question non essentielle. Je dois expliquer encore plus longuement la question de ma conversation avec le P[ère] Siwek à Cracovie. Je ne le connaissais pas avant mes conférences, que j'y ai eues. J'avais seulement entendu de la part de certains Pères, que le P[ère] Siwek est un antagoniste de Konnersreuth et on me répéta même ses arguments, par lesquels il attaquait ce problème. Quand j'arrivai à Craoovie pour mes conférences, j'ai voulu connaître le P[ère] Siwek et parler avec lui. Premièrement car je cherche partout, aussi a l'étranger, pour entendre leur opinion sur Konnersreuth, les hommes qui s'en occupent. J'en ai parlé par exemple à Vienne avec le professeur Alers ${ }^{83}$, à Lwów avec le professeur Halban ${ }^{84}$, avec le professeur Mager et d'autres à Salzbourg, Münich, Eichstätt ${ }^{85}$.

Ensuite puisque je préparais un livre sur Konnersreuth je voulais connaître les reproches que le P[ère] Siwek faisait à ce problème. J'en priai de même le professeur Westermayr ${ }^{86}$ de m'écrire les siens; il le fit et nous entrâmes en correspondance. Voilà les causes pourquoi je désirais avoir un contact avec le P[ère] Siwek.

Je l'invitai à venir a mes conférences; je le priai de me dire son opinion et j'essayai de lier conversation avec lui au sujet de Konnersreuth. Mais ces essais furent vains. Je sentais que le P[ère] Siwek se renferme devant moi. Il ne me dit même pas qu'il a l'intention d'écrire un livre sur Konnersreuth. Il répondait à mes questions d'une manière évasive. J'appris beaucoup plus de ses compagnons sur ses arguments. J'en fus tellement frappé, que quand le „Przegląd Powszechny” commença à publier les articles du P[ère] Siwek, je demandai à un des Pères à quoi dois-je attribuer ce manque de franchise envers moi, qui avait parlé si ouvertement avec lui.

Je me souviens que je l'avais questionné sur la psychosténie, qui à cette époque ne m'était pas bien connue dans ses détails. J'aurais pu les puiser plus abondamment

${ }^{83}$ Właściwie: Allers Rudolf (1883-1963), austriacko-amerykański psychiatra, psycholog i filozof. Zajmował się m.in. filozoficznymi podstawami medycyny i psychologii medycznej, 1918-1938 profesor w Instytucie Fizjologii w Wiedniu, w 1938 r. wyemigrował do Stanów Zjednoczonych gdzie prowadził wykłady z filozofii i psychologii w Katolickim Uniwersytecie Ameryki w Waszyngtonie i Georgetown University tamże. Allers Rudolf, w: DBE, Bd. 1, herausg. von W. Killy, München 1995, s. 91.

${ }_{84}$ Zob. w niniejszej publikacji: J. Wołczański, Korespondencja abp. Józefa Teodorowicza z prof. Stefanem Dąbrowskim, dokument 42.

${ }^{85}$ Eichstätt - miasto powiatowe w Bawarii w Niemczech.

${ }^{86}$ Westermayr Johann - niemiecki rzymskokatolicki duchowny, dr teologii, w latach $30 \mathrm{XX}$ w. rektor Seminarium Duchownego we Freisingu. 
dans la première encyclopédie venue que ne l'a fait le P[ère] Siwek, mais en sentant qu'il se ferme devant moi, je me contentai d'une discussion qui n'avait pas de stricte liaison avec le problème de Konnersreuth. Car si on voulait expliquer ces phénomènes par l'hystérie, il faudrait s'y prendre aux phénomènes le moins subtils comme le somnanbulisme, comme le dédoublement de la personnalité, avec lesquels les légères manifestations de la psychosténie ne sont pas liées. Dans des conversations pareilles, j'ai la coutume de noter quelques opinions du savant avec lequel je parle, mais d'ordinaire ces notes se perdent dans deux ou trois jours, si elles ne sont pas essentielles pour le problème qui m'occupe.

Si donc le P[ère] Siwek s'est donné tant de peine pour noter sa conversation avec moi, c'est si je me la rappèle bien, en de grosses lignes et il devra avouer, que le gros de la conversation se rattachait à un chemin latéral, qui n'avait rien de commun avec la grande route qui mène à Konnersreuth. La seconde question se rattache à la publication de la lettre de S[on] E[xcellence] l'Evêque Buchberger. Vous avez certainement écrit au Prince Métropolite Sapieha, que l'Evêque Buchberger était mécontent qu'on avait publié sa lettre. J'en serais bien étonné, car quand le P[ère] Siwek se référait continuellement au Consistoire de Regensburg dans sa réponse qu'il m'avait donnée, j'avais traduit alors tous les passages de son livre qui se rapportaient aux révélations du Consistoire de Regensburg et je les envoyai à l'Evêque Buchberger avec l'original polonais, j'exprimai en même temps que je ne savais pas qu'y répondre et que je le prie de m'envoyer ses éclaircissements. Il va de soi qu'ils ne pouvaient venir que de l'Evêque et qu'ils n'auraient de l'importance que si on les publie et les oppose aux fausses notes du P[ère] Siwek.

Je ne pouvais comprendre autrement la réponse de S[on] E[xcellence] l'Evêque Buchberger, qui n'avait donné aucunes restrictions quant à la discrétion. J'ai envisagé cette réponse non comme une lettre privée, mais comme un document public, destine au but, pour lequel j'avais prié de me l'envoyer.

\section{[Wersja ${ }^{87} \mathbf{w}$ j. polskim:]}

Wielce ${ }^{\mathrm{a}}$ Czcigodny Ojcze Generale!

Otrzymałem właśnie dwa listy Najprzewielebniejszego O. Generała i dziękując za nie, odpisuję.

\section{Udział Ojca Generała}

Co do udziału w tej sprawie Najprzew[ielebniejszego] Ojca Generała, to jak widzę, Ojciec Generał uważa, że mój zwrot użyty w liście o roli Ojca Generała w sprawie wydania dwu książek O. Siwka, iż to, co zostało uczynione, wolno było uczynić, mówi za mało i nie uwypukla dostatecznie usunięcia się Ojca Generała zupełnie z gry.

87 AFKDOPW, teczka 132: Spuścizna abp. Józefa Teodorowicza, sygn. 1606/185 [4], List abp. Józefa Teodorowicza do o. Włodzimierza Ledóchowskiego SJ, bmr., mps.

a Tekst pisany maszynowo na 35 stronicach papieru formatu A4. Brak autografu autora pisma. 
Pozwolę sobie przypomnieć Ojcu Generałowi, że się broniłem w ostatnim liście tylko przed zarzutem Ojca Generała, jakobym Go pomawiał o walkę z Ks.Ks. Biskupami; na obalenie tego zarzutu wystarczył ten zwrot, którego użyłem i który Ojciec Generał w swym obecnym liście przedstawia. Natomiast daruje mi Ojciec Generał, że w całej tej sprawie O. Siwka musiałem tak sądzić, jak sądziłem, iż moralna odpowiedzialność w znacznej mierze spoczywa jednak na Ojcu Generale. Zarówno cytaty O. Siwka powołującego się na niezwykłą pochwałę Ojca Generała daną przez asystenta po przeczytaniu manuskryptu, jak zakaz pierwotnie zawieszony przez Ojca Generała na jeden najmniej angażujący O. Siwka artykuł „Przeglądu”, jak list O. Rostworowskiego powołującego się wobec Ks. Biskupa krakowskiego wyraźnie na rozkaz bezpośredni z Rzymu wydania drugiej książki, jak związek moralny pomiędzy wskazaniem O. Siwka mnie, który przez prelekcje krakowskie rzucił niepokój w serca wierzące - wszystko to razem wzięte jest zbyt jasne i wymowne, ażebym mógł w liście do O. Prowincjała inaczej osądzić rolę Ojca Generała, jak osądziłem.

\section{Dlaczego pisałem krytykę książki O. Siwka?}

Najpierw zarzuca mi Ojciec Generał, iż w ogóle pisałem krytykę pracy O. Siwka. Pozostaje mi tu odpowiedź na propozycję O. Generała przedstawioną Ks. B[is]k[u]p[owi] Przeździeckiemu, o której obecnie mi Ojciec Generał pisze. Propozycja wprawdzie spóźniona; o ile ją dobrze zrozumiałem opiewała tak, iż Ojciec Generał sądzi, że powinienem był zamiast pisać rozprawę w odpowiedzi O. Siwkowi, a raczej zamiast pisać pierwszą krytykę jego książki, zwrócić się do Ś[więtego] Officium z zażaleniem na O. Siwka. Przyczyny dla których na tę drogę nie poszedłem są następujące.

1) Przede wszystkim był nią szkodliwy wpływ książki O. Siwka. Wiadomo z pewnością Ojcu Generałowi, że książka może zaszkodzić duszom nawet wtedy, kiedy nie jest przeciwna wierze i dogmatom. Mamy nawet w ostatnich czasach przykład w dziedzinie egzegezy: pisarze, którzy stoją na stanowisku nadprzyrodzonym, jednak czy to skutkiem wyolbrzymienia pierwiastku przyrodzonego kosztem nadprzyrodzonego, czy skutkiem innych przyczyn, dostają się nawet na indeks. Nie twierdzę tego bynajmniej jakoby książka O. Siwka na taki los zasługiwała, ale stwierdzam na podstawie dużego doświadczenia, że jej wpływ był z wielu stron dla dusz szkodliwy. Mogę na to przytoczyć cały szereg bardzo konkretnych dowodów.

Nie w tym tkwiła tajemnica jej złego wpływu, iż O. Siwek odnosił się sceptycznie do zjawisk w Konnersreuth, ale w czymś innym zupełnie. W tym mianowicie, że O. Siwek oparł poznawalność zjawisk mistycznych na samych analogiach psychopatycznych i poniechawszy kryteria mistyczne, nie podał pośród podobieństw różnic zasadniczych między psychopatią a mistyką. Stąd pytali ludzie: ależ w takim razie jakąż mamy pewność, że zjawiska mistyczne św. Teresy nie były także histerią?, że stygmaty św. Franciszka nie były produktem wyobraźni? Po książce O. Siwka - mówiono - nie ma żadnej pewności co do stanów prawdziwych mistycznych. Ileż razy takie zdania obijały się o uszy moje! Stąd przerzucano ten sceptycyzm i na cuda; zwłaszcza wśród młodzieży 
książka w duszach czyniła istne spustoszenie, zachwiała wiarą wielu osób. O tym ja wiem bezpośrednio i pośrednio.

Ojciec Generał dotyka w swym liście i wspomnień osobistych, i względów na O. Siwka. Te wspomnienia zachowałem i żywe, i jako zawsze mi drogie. Co zaś do O. Siwka, to po Krakowie, przed napisaniem książki zachowałem dla niego uczucie sympatii. Jeśli jednak wziąłem się do napisania krytyki jego pracy to tylko dlatego, że skutki jej metody zaobserwowane przeze mnie bezpośrednio nakazały mi ponad wszystko postawić interes dusz wołających: dotąd myśleliśmy, że tak rozumuje racjonalizm, ale Kościół ma na to odpowiedź; dzisiaj widzimy, że tak samo rozumuje o kryteriach mistycznych kapłan - zakonnik i profesor Gregorianum!

Nie wchodzę w meritum tych wypowiedzeń, ale sądzę, że gdyby nic więcej książka O. Siwka nie zawierała jak tylko nieścisłość, to skoro dała asumpt do obałamucania sumień, już w tym był dostateczny powód dla mnie, ażeby zabrać głos. W samej zaś rzeczy w książce O. Siwka pominięcie kryteriów mistycznych było czymś więcej niżeli tylko niejasnością i nieścisłością. I stąd uważałem za swój obowiązek sumienia publicznie wystąpić.

2) Druga przyczyna mojego publicznego wystąpienia tkwiła w tym, iż nie wychodziłem w krytyce mojej z żadnego założenia teologicznego, ale punktem mojego wyjścia było założenie ogólnonaukowe, które dotyczyło błędnej metody naukowej w pracy O. Siwka. Moje postawienie problemu było proste: mistyka jest wiedzą teologiczną i eksperymentalną; każda zaś wiedza w swojej dziedzinie posługuje się wiedzą pomocniczą, ale nie daje się jej nigdy wyręczać w ostatecznych konkluzjach. I przytoczyłem przykład z dziedziny historii, która nie pozwala na to, ażeby ją wyręczała w ostatecznej konkluzji pomocnicza nauka archeologii. Moje więc założenie na punkcie wyjścia w krytyce O. Siwka było ściśle naukowe i ktokolwiek uznaje mistykę za wiedzę, ten bez względu na to, czy jest wierzącym, czy niewierzącym musi mi przyznać słuszność.

To więc jest właściwy zarzut, który podając wyraziłem się nadto, że w pracy O. Siwka „jest wyolbrzymiony pierwiastek psychofizyczny a obniżony zupełnie, pomimo wręcz innych pozorów, pierwiastek mistyczny” („Ateneum Kapł[ańskie]” str. 4).

Oto są przyczyny dla których nie mogłem się odnieść do Ś[więtego] Officium; jeżeli zaś źle zrozumiałem list Ks. B[is]k[u]p[a] Przeździeckiego, to najlepszym w takim razie wytłumaczeniem są słowa Ojca Generała, który list Ks. B[is]k[u]p[a] Przeździeckiego kwalifikuje jako „nie dość jasny”, a na innym miejscu wręcz, „że był niejasny”.

3) Co do punktu wyjścia mojego, iż problem przeze mnie obrabiany dotyczył ogólnego charakteru każdej nauki, a więc i mistyki i że jako taki nadaje się tylko do rozprawy naukowej, to pośrednio stwierdził i O. Generał udzielając pozwolenia O. Siwkowi, ażeby mi dał odpowiedź na zarzuty jemu postawione.

Albowiem dając pozwolenie na to, ażeby w drodze dyskusji naukowej spór rozstrzygnąć, stwierdził tym samym O. Generał, że spór należy do dziedziny ściśle naukowej. Dlatego muszę wyrazić Ojcu Generałowi swoje zdziwienie, iż grozi mi oskarżeniem do Ojca św., czyli, że wciąga tę sprawę na tory, na których ją rozstrzyga najwyższy autorytet kościelny. 
Przy tym jeszcze dowiaduję się z listu O. Generała, że i O. Siwek da mi jeszcze odpowiedź, której dotychczas dla jakichś przyczyn dać nie może. Niech mi O. Generał nie weźmie za złe gdy powiem, że się w takim sposobie postępowania zupełnie wyznać nie potrafię. Biorę dla ilustracji przykład z życia, choć bardzo niedokładny. Ludzie rozstrzygają sprawy na przykład honorowe w sposób dwojaki; albo je oddają pod rozstrzygnięcie sądu honorowego, albo też idą z tą sprawą do sądu zwyczajnego. Ale nikt, kto raz sprawę skierował na tory sądu honorowego, nie zwraca jej potem powtórnie do sądu zwyczajnego i to jeszcze z tym dodatkiem, że ją ostatecznie znowu podda sądowi honorowemu.

Tak samo też nie mogę zrozumieć charakteru interwencji Ojca św., która miałaby zastępować i wyrównywać to, co się wdrożyło na tory dyskusji naukowej i ją likwidować, mimo że jeszcze raz ostatecznie zamierza się powrócić do dyskusji naukowej, ostatnie słowo oddając O. Siwkowi. Przykro mi niemiernie, że O. Generał bierze tę dyskusję naukową tak bardzo osobiście, skoro przecie podobne dyskusje i sprawy sporne toczą się nieraz nawet w łonie samych Ojców; jak na przykład pomiędzy Fröbesem a Lindworskim.

W szczególności co do Konnersreuth, jakże gorąca rozprawa toczyła się pomiędzy prof[esorem] uniwersytetu Magerem a prof[esorem] uniw[ersytetu] szwajcarskiego O. Lavaud, gdzie wchodziły nawet kwestie pierwszorzędnej wagi teologicznej, jak na przykład o Chrystusie przemawiającym w duszach.

Jeśli zaś nawet te argumenty, które tu przytoczyłem dla osobistego ujmowania kwestii ze strony O. Generała są niewystarczające, to dodatkowo przypomnę to, o czym O. Siwek doskonale wiedział, że przygotowywałem duże dzieło o Konnersreuth. A więc już jeśli nie z tych względów, które były dla mnie zasadnicze i rozstrzygające, ale z tytułu obowiązku autora piszącego książkę o jakimś temacie, musiałem rozprawić się z pracą O. Siwka tak głęboko wnikającą we wszystkie dziedziny tego problemu. Już z tego jednego tytułu nie mogłem absolutnie wyminąć rozprawy z O. Siwkiem, której starałem się nadać najmniej rozgłośny charakter, albowiem zamiast ją pomieścić w dziele niemieckim, które piszę, ograniczyłem się do artykułów fachowego pisma „Ateneum Kapłańskiego".

\section{Krytyka a miłość}

Zarzuca mi Najprzewielebniejszy O. Generał, że w mojej krytyce nie stosowałem pięknej zasady św. Ignacego i św. Pawła o miłości i wyrozumiałości, tylko byłem bezwzględny. Odpowiem na ten zarzut faktami.

Czyniąc O. Siwkowi zarzut, który - przyzna O. Generał - jest zupełnie słuszny, iż za pomocą kryteriów psychopatycznych przesądza o zjawiskach mistycznych bez kryteriów mistycznych, staram się wszystko uwzględnić, co na korzyść O. Siwka przemawiać może. Sam O. Generał wyciąga z moich listów takie słowa, które piszę na korzyść O. Siwka w odniesieniu do zasadniczego problemu. Dodaję tutaj jeszcze kilka moich tekstów. 
Pisząc o tym, że O. Siwek posługuje się kryteriami psychopatycznymi z pominięciem kryteriów mistycznych wyraźnie zaznaczam: „Na wstępie należy z uznaniem podnieść duże oczytanie się O. Siwka w literaturze psychofizjologicznej, uderzające opanowanie tego przedmiotu, łatwość wielką w przedstawieniu tych trudnych problemów naukowych i lekkość pióra” („Aten[eum Kapłańskie]”, str. 3). Piszę także: „Sądzę, iż gdyby autor zamiast podejmować się rozwiązania problemu w świetle nauki i religii ograniczył się do skromniejszego zakresu i gdyby był sobie tylko wytknął za zadanie zebranie materiału naukowego i to tylko pod jednym kątem widzenia do problemu Konnersreuth, byłby dzięki swojej erudycji z zakresu psychologii oddał niewątpliwe przysługi w badaniu tego problemu" (tamże, str. 213).

Lecz nawet $w$ kwestiach najdrażliwszych, bo w stwierdzeniu, że i racjonalizm także, choć z innych powodów nie uwzględnia kryteriów mistycznych, strzegłem się jak najbardziej tego, aby nie zarzucić O. Siwkowi formalnego racjonalizmu. Pisałem: „Dzieje się to wszystko mimo świadomości autora, który jest osobiście szczerze pobożnym i głęboko wierzącym, a przy tym pisarzem najlepszej woli, ale należy bezsprzecznie do rzędu tych katolickich pisarzy, którzy hołdują bodaj czy nie nazbyt metodom wyłącznie eksperymentalnym psychologów niezależnych, czerpiąc przede wszystkim informacje i metody z ich dzieł" (tamże, str. 4). Sam O. Siwek przytacza mój inny cytat, w którym mówię o nim, iż jest „na przeciwnym biegunie ich (racjonalistów) stanowiska”.

Wyjaśniwszy moje stanowisko sądzę, że o ile ono jest obroną O. Siwka przed wszelkim zarzutem formalnym przeciw wierze i racjonalizmowi, o tyle jest przystosowaniem pięknego zdania św. Ignacego, który tu podaje O. Generał: „supponendum est, Christianum unumquemque pium debere promptiore animo sententiam seu propositionem obscuram alterius in bonam trahere partem quam damnare".

\section{Zniekształcenie moich tez}

W liście do O. Generała napiętnowałem artykuły „Czasu” i „Dziennika Poznańskiego” napisane przez jednego z Ojców jako kłamstwo i pychę, i te dwa określenia przeniosłem na pracę O. Siwka, ażeby wskazać, że ma ona te same cechy przewodnie. O. Generał oburza się na to i uważa te zarzuty za "niesłuszne i obiektywnie ciężko O. Siwka krzywdzące".

Otóż jest w tym pewne nieporozumienie. Powołuję się tutaj na list Najprzew[ielebniejszego] O. Generała pisany do mnie, który był odpowiedzią na mój zarzut konkretny, iż O. Siwek w liście do jednej z redakcji nazwał mnie oszczercą. Wtedy O. Generał broniąc O. Siwka wskazał na różnicę pomiędzy nazwaniem kogoś oszczercą, a pomiędzy określeniem, że coś jest oszczerstwem. Otóż to rozróżnienie O. Generała biorę teraz dla siebie, jako odpowiedź na Jego słowa. Ja nie nazwałem O. Siwka kłamcą, tylko powiedziałem, że w książce jego jest kłamstwo.

Jeżeli więc O. Generał broni tym argumentem O. Siwka, iż on mnie nie obraził i że mnie ciężko nie skrzywdził, bo nie powiedział prawdopodobnie, że ja jestem oszczercą to dlaczego w wypadku analogicznym O. Generał używa innej miary do mnie i mojego 
napiętnowania i uważa je - gdy idzie o O. Siwka - za ciężko krzywdzące. Prosiłbym więc Najprzew[ielebniejszego] O. Generała o równą i sprawiedliwą miarę w sądach w tych dwóch wypadkach tak klasycznych dla całej obrony O. Siwka. Następnie pisałem o kłamstwie tylko w liście moim prywatnym do O. Generała, nie użyłem zupełnie tego wyrażenia w mojej książce. I znowu tu się powołam na następujące zdanie O. Generała: „Pozwalam sobie też zwrócić uwagę, że jak mój poprzednik, znakomity kanonista, słusznie podnosił, iż nie można nigdy szukać w zwyczajnych listach i rozmowach kanonicznej ścisłości - mówił w zwykłych swych listach - i trzeba je zawsze tłumaczyć nie tylko z kontekstu, ale z całego stanu sprawy".

W ogóle O. Generał czyni mi najdotkliwszy zarzut, jaki mi uczynić można, jakobym wyrządził O. Siwkowi wielką krzywdę. Czyż się godzi lansować podobny zarzut bez wyraźnego wymienienia, w czym O. Siwkowi krzywdę wyrządza. Bez takiego uzasadnienia zarzut staje się ogólnikowy i dlatego gołosłowny,

Dlatego zmuszony jestem sam postawić pytanie, które zarzuty O. Siwkowi krzywdę uczyniły. Czy może uczynił ją zarzut, że przez kryteria psychopatyczne przesądza o zjawiskach mistycznych? Ale przecie nie tylko cała książka, ale i jego własne słowa to stwierdzają.

Czy może zarzut nieznajomości zjawisk w Konnersreuth jest tak krzywdzący dla O. Siwka? Ale to wykazałem przecie na podstawie własnej obserwacji. Stwierdziłem więc zarzut przez konkretne fakty.

Czy może krzywdzącym jest zarzut, że swoje twierdzenie ujemne o Teresie Neumann zamiast o świadectwa poważne oparł o zdania anonimowe? Ale każdy, kto tylko przeczyta odpowiedź O. Siwka, o tym przekonać się może.

Więcej zarzutów O. Siwkowi nie czyniłem, prócz jednego jeszcze, a mianowicie, że zniekształcił wszystkie moje tezy. Tym zarzutem zajmę się osobno, gdyż O. Generał stara się go odeprzeć.

Pisze mi O. Generał: „Zarzut ten zdaje mi się także obiektywnie krzywdzący O. Siwka, gdyż formalnego i świadomego sfałszowania prawdy nie można mu udowodnić. Dla przykładu biorąc chociażby tylko cytat przytoczony w książce Waszej Ekscelencji: «Zjawiska mistyczne i ich tłumaczenia» na str. 218, pozwalam sobie zwrócić uwagę, że inni poważni ludzie i to nie zanadto przychylni dla O. Siwka odnieśli wrażenie, iż nie widzą tego sfałszowania”. Pisze dalej O. Generał, że „mogą się u O. Siwka zdarzać pewne niejasności i niedociągnięcia, nawet sprzeczności, co oczywiście przy większej ekscytacji łatwo może mieć miejsce. Ile razy widzimy przede wszystkim tu w Rzymie - a wiem, że osoby wyżej położone to samo stwierdzają - jak głęboką prawdę psychologiczną zawiera znany aksjomat scholastyków: «Quidquid recipitur, secundum modum recipientis recipitur». Stąd się zdarza, że ludzie poważni, o których dobrej wierze wątpić nie można czasem zupełnie przemieniają to, co im się powiedziało”.

Całe przeciwieństwo pomiędzy obroną O. Generała a moim twierdzeniem występuje tu jasno. Ja bowiem twierdziłem, że O. Siwek przeistoczył moje zasadnicze stanowisko dla swoich celów i dokonał tej metamorfozy przez zniekształcenie moich tez, mniejsza o to, jak to zniekształcenie rzeczy nazwiemy, czy kłamstwem, czy też najprostszym fałszerstwem moich idei przewodnich. Tymczasem O. Generał tłumaczy tę przemianę 
tylko pewnym nieporozumieniem i niedociągnięciem, może nawet sprzecznościami, zupełnie przypadkowymi i niecelowymi.

Wobec tego tłumaczenia O. Generała zadaję sobie pytanie, czyżby to istotnie mogło być tylko czymś przypadkowym, jakimś niedopatrzeniem O. Siwka, jakimś niedowładem jego myśli, iż tyle razy i tak kategorycznie przeze mnie podkreślone stanowisko niewchodzenia w meritum sprawy Konnersreuth on zmienia doszczętnie? Czyż podobna pomyśleć, aby przypadkowi przypisać tak zupełne zapoznanie zasadniczego mojego stanowiska i takie jego przeistoczenie? Miałożby to być tylko niedopatrzeniem, iż moje zastrzeżenie, że nie wchodzę w to, czy zjawiska w Konnersreuth są prawdziwe, czy też fałszywe tak przeistoczył O. Siwek, iż wyszedłem z tej jego metamorfozy, jako zaciekły i niekrytyczny obrońca cudowności Konnersreuth?

Jeżeli O. Siwek aż do tej miary nie mógł zrozumieć moich przewodnich idei w tylu analizach przeprowadzonych, to $\mathrm{w}$ takim razie co za wyobrażenie mieć by należało o umysłowości O. Siwka? A jakżeby równocześnie wytłumaczyć można, iż dziwnym trafem te właśnie niedopatrzenia O. Siwka ułożyły się na jego główny plan apologetyczny, oparty na zniekształceniu moich tez a przeprowadzony tak w całości, jak i w szczegółach z mistrzowskim wprost sprytem!

Nie, Najprzew[ielebniejszy] O. Generale, podobna obrona jest tylko oskarżeniem O. Siwka. Jeśliby bowiem prawdą było, że tak celowe zniekształcenia moich tez przez O. Siwka były przypadkiem, były niedopatrzeniem, były niezrozumieniem z jego strony mej myśli, to w takim razie musiałoby się przypuścić, że O. Siwek nie umiał dojrzeć ani razu od początku do końca moich tez, że zawsze je przekręcał, że więc złożył dowód najwyższego umysłowego niedołęstwa. A przecież O. Siwek jest bardzo bystry i zdolny. $\mathrm{Z}$ drugiej znowu strony musiałoby się przypuścić, że z tych jego zapoznań niezrozumień raptem wyskoczył cały konsekwentnie i celowo przeprowadzony plan.

To wszystko musiałoby się przypuścić, gdyby prawdziwe było twierdzenie, że ja niesprawiedliwie osądzam O. Siwka nie biorąc w rachubę zasady scholastyków: „Quidquid recipitur, secundum modum recipientis recipitur!” Czy to jest możliwe? Nie! Bo ani podobna przypuścić przypadkowości w takiej celowości, jaką wykazałem na całym szeregu stron mojej książki, ani nie można pomówić O. Siwka znanego ze swej zdolności i talentu o umysłowy niedowład.

Ale O. Generał na dowód, iż moje oskarżenie o zniekształcenie tez przez O. Siwka nie jest prawdziwe, przytacza jeden cytat na stronicy 218-tej. Pytam, co znaczy jeden cytat, czy też jeden ustęp w całej powodzi ustępów? Świadczyłby on właśnie, że tam, gdzie nie można nic więcej w tak wielkim oskarżeniu przytoczyć, jak jeden tylko szczegół choćby niewątpliwy, to oskarżenie jest uzasadnione. Ale nawet ten jeden cytat, który O. Generał przytacza, jakkolwiek w ścisłym jest związku z moralnymi metodami O. Siwka, nie został przeze mnie pomieszczony na liście argumentów, które przytoczyłem na dowód dokonanych przez O. Siwka zniekształceń moich tez.

Tezy moje, które zostały zniekształcone przez O. Siwka, pomieściłem pt. „Zniekształcone tezy", od str. 42-62, wyliczając zniekształcone moje myśli i przechodząc je po kolei pod tytułami: ekstazy, stygmatyzacja, łaski darmo dane, proroctwa, języki, typ Teresy 
Neumann. Prócz tego pomieściłem zniekształcenie mojego poglądu na badanie cudu przez O. Siwka w obszernej rozprawie o uzdrowieniach Teresy Neumann w mojej książce, w której od str. 222 do 231, a więc na czterech przeszło kartach druku wykazałem, jak O. Siwek zniekształcił zasadniczą moją tezę w poglądzie na cud i to zniekształcił iście koronkową robotę celowo, ażeby moją rzekomo tezę, zupełnie naukowo bezkrytyczną i naiwną, przeciwstawić swojej tezie naukowej. Prócz tego w rozprawie o głodzie jeszcze raz potrącam o tę kwestię.

Dlatego sądzę, że jeżeli Ojcu Generałowi powiedzieli uczeni, że nie miałem słuszności w zarzucaniu O. Siwkowi zniekształcenia moich tez, to musieli to być uczeni nieznający języka polskiego, którym został przedłożony tekst tylko w języku francuskim; nieprzedłożono im natomiast równocześnie mojej pracy $\mathrm{w}$ tłumaczeniu francuskim. W takim razie - rzecz naturalna - iż wierząc autorowi, że prawdziwe moje teksty przytacza musieli orzec, że nie widzą w tym żadnego zniekształcenia. Tak na przykład ks. dr Steuer, do którego jeszcze powrócę, czytając odpowiedź O. Siwka, napisał życzliwą recenzję o tej pracy do „Przeglądu Teologicznego”; ale kiedy mu z Konsystorza poznańskiego dano do recenzji moją książkę dla aprobaty, przekonał się o właściwej wartości pracy O. Siwka i natychmiast wycofał swoją recenzję, jeszcze nieogłoszoną w „Przeglądzie Teol[ogicznym]”, a ogłosił inną w „Ateneum [Kapłańskim]”. Muszę tu nawiasem dodać, że o tym nie wiedziałem i dowiedziałem się dopiero ex post.

Otóż, gdyby ci uczeni mieli takie samo tłumaczenie francuskie mojej pracy, jak mieli tłumaczenie pracy O. Siwka, to bym w ogóle w to uwierzyć nie mógł, ażeby rozgrzeszyli O. Siwka z dokonanego przez niego zniekształcenia moich tez. Przecie dowody, jakie przytoczyłem nie dadzą się obalić, bo to są cytaty przytoczone z mojej dawnej pracy i ze słów O. Siwka oświetlających ją. Cytat to tak jak liczba w dowodzie. Jeżeli więc wykazuję cytatami, że powiedziałem to a to, jeżeli równocześnie drugim cytatem wskazuję, że O. Siwek nie zniekształcił mojej pozycji znaczyłoby tyle, co twierdzić, że $2+2$ jest 5 ! Jak zaś łatwo dojść do sedna rzeczy bez niebezpieczeństwa zabłąkania się w podrzędnych szczegółach, to wskażę O. Generałowi tylko dwa cytaty, na których od razu poznać zniekształcenie i to zniekształcenie najistotniejszej rzeczy, bo zniekształcenie mojego poglądu na krytykę zjawisk nadprzyrodzonych.

Pisząc o hipotezie O. Siwka, iż nie można nic pewnego orzec o nadprzyrodzonym charakterze uzdrowień Teresy Neumann, zgodziłem się na tę tezę O. Siwka wyraźnie stwierdzając, iż „nic nie możnaby zarzucić podobnemu założeniu i rozwiązaniu przez ostateczne non constat”. („Ateneum [Kapłańskie]”, str. 8).

Jeżeli O. Siwek opuszcza to moje wypowiedzenie, a dochodzi do wniosku wręcz przeciwnego i przedstawia mnie, jako niekrytycznego wroga jego stanowiska non constat, to każdy wie od razu, co ma o takiej metodzie postępowania sądzić. Każdy, nie potrzeba na to komisji ani żadnych znawców, od razu powie, że to jest zniekształcenie. A jak złośliwie, z jaką sugestią podsuwa mi O. Siwek tezę przez siebie skomponowaną - o tym świadczą następujące słowa: „W metodach, jakimi się posługuje w tym celu, by pokazać «możliwość» - bo tylko w ten sposób kwestie stawiam uzdrowień na drodze naturalnej - widzi On «poważne niebezpieczeństwo». Bo czym się one np. różnią istotnie od 
tłumaczeń naturalistycznych uzdrowień, przynajmniej wielu w Lourdes? A warunki, jakie one przywiązują do cudu prawdziwego, czyż nie sięgają daleko poza Konnersreuth?” („Metody”, str. 13).

Drugie zniekształcenie, które tu przytaczam mojego stanowiska wobec zjawisk mistycznych dotyczy ekstazy, porywów mistycznych itd. Otóż w tej mojej tezie niedwuznacznie zarzuciłem O. Siwkowi brak dostatecznej krytyki naukowej, a w każdym razie wymagałem jej niezbędnie dla stwierdzenia tychże zjawisk: „To dopiero drogą analizy naukowej należy stwierdzić, albo też nie stwierdzić, gdyż krytyce naukowej a ścisłej nie wolno przyjmować za pewnik jakby na kredyt to, co dopiero analiza powinna wykazać" („At[eneum Kapłańskie]”, s. 317).

Cóż z tej tezy mojej zrobił O. Siwek? Zmieniwszy nadto zupełnie charakter mojego określenia zaliczył mnie do łatwowiernych, bezkrytycznych, uderzających w niego za krytykę i wołających: „Ekstaza Teresy Neumann to dzieło transcendentne wszechmocy Boga, to cud Boży!” („Met[ody]”, str. 74). Ukoronowaniem tego zniekształcenia mojej tezy jest wykrzyknik bolesny O. Siwka: „Jak boleśnie mnie musiało dotknąć, gdym przeczytał relacje mojej konkluzji w tej mniej więcej formie: ekstazy Teresy nie mogą być nadnaturalne, ponieważ podobne cechy znajdujemy również w patologii” („Met[ody]”, str. 75). Poddaje mi też jeszcze dyskretnie O. Siwek, jakobym czynił zarzut herezji. Pisze on: „Nie ma żadnego dogmatu wiary, z którego by metodą takiego referowania nie można było zrobić formalnej herezji. Ot[o] Piotr wypowiada zdanie takie: Bóg nie mógł stworzyć świata z konieczności - dogmat wiary! Paweł, cytując słowa Piotra mówi: Bóg nie mógł stworzyć świata! - herezja! („Met[ody]”, str. 75).

Otóż na tych dwu tezach zniekształconych oparł O. Siwek mój stosunek do zjawisk nadprzyrodzonych i mój stosunek do oceny cudów tak nienaukowo, tak bezkrytycznie, tak wobec badań naukowych niesprawiedliwie, że te dwa teksty zniekształcenia zupełnie wystarczą, ażeby mnie zdyskredytować w dziedzinie naukowej raz na zawsze.

A właśnie na zniekształceniu tekstów moich o cudach i zjawiskach nadprzyrodzonych opiera O. Siwek wielką kolubrynę, godzącą we mnie, jako człowieka, który wszędzie widzi cudowność, który go właśnie gani za to, że on swoim non constat stwierdza potrzebę ostrożności. Jeszcze w artykule „Dziennika Pozn[ańskiego]” widzę echo tego planu, gdzie autor artykułu dokonuje zniekształcenia mej myśli w samym tytule: Nie śpieszmy się w ocenie „cudów” z Konnersreuth.

To jest założenie jego programu polemicznego, to jest sekret jego strategii wobec mnie, którą wykazałem na dziesiątkach całych stron mojej książki. Praca ta zniekształciła, jak to wykazałem w niektórych miejscach, jest przeprowadzona z niesłychaną zręcznością i celowością, wprost rafinowana.

To, co tu mówię, jest proste jak na dłoni. Ktokolwiek przeczytał daną mi odpowiedź O. Siwka ten widzi jasno, że od początku do końca - jak to zaznaczyłem - odpowiedź cała opiera się właściwie na dwu zdaniach.

Pierwsze wyraża stanowisko O. Siwka, które on przedstawia, jako zgodne z krytyczną wiedzą i wolą Kościoła. Jest to stanowisko, które zjawiskom nadprzyrodzonym przeciwstawia ścisłą krytykę naukową. 
W drugim zdaniu jest znowu przedstawione wręcz przeciwne stanowisko moje. Ja bowiem mam za złe O. Siwkowi jego krytycyzm i domagam się uznania nadprzyrodzoności zjawisk w Konnersreuth bez krytyki rzeczowej. W tych dwu zdaniach jest rozwiązanie zagadki całego, jak już powiedziałem, strategicznego ataku O. Siwka na mnie.

A teraz pytam: czy jest możliwy podobny atak przy wiernym przedstawieniu moich tez? Taki atak, który jest zarazem obroną jest zupełnie nie do pomyślenia w razie, gdyby O. Siwek chciał moje tezy przedstawić tak, jak ja je przedstawiłem. Albowiem niemożliwe jest twierdzenie, jakobym ja był za bezkrytycznym uznaniem zjawisk nadprzyrodzonych w Konnersreuth, skoro się tylokrotnie zastrzegłem, iż się nie wypowiadam ani za, ani przeciw nadzwyczajności i cudowności tych zjawisk. Niemożliwym tedy było O. Siwkowi stać na wysokich koturnach krytycznej nauki w przeciwieństwie do mnie, skoro tak wyraźnie w mojej pracy zarzucałem O. Siwkowi dyletantyzm naukowy, powierzchowność, brak elementarnych znajomości zjawisk o których pisze, a z którymi się nie zapoznał, wreszcie brak wgłębienia się w przedmiot przez włączenie kryteriów, które wśród samych podobieństw wykażą różnicę. Jeśli więc O. Siwek chciał przeprowadzić moją główną ideę polemiczną ze mną i stoczyć ze mną zwycięską walkę, to nie miał do wyboru nic innego, jak tylko zniekształcić wszystkie moje tezy od „a” do „zet”.

Ten sposób, który ma służyć mu z jednej strony do uchylenia od polemiki na polu właściwym, a z drugiej do uderzenia we mnie za merytoryczne stanowisko wobec Konnersreuth, przeciw któremu się tak zastrzegałem, jest głównym znamieniem pracy O. Siwka. Dlatego daruje mi O. Generał, iż muszę odnieść wrażenie, iż O. Generał nie znalazł czasu na przeczytanie mojej pracy, jeżeli pisze o tym tylko tyle, „że mogą się u O. Siwka zdarzać pewne niejasności, co oczywiście przy większej ekscytacji łatwo może mieć miejsce".

Każdy też zrozumie, że właśnie tak systematycznie przeprowadzony plan, który z gruntu przemienia moje tezy, który zniekształca zupełnie tekst mojego listu prywatnego, nie może być potraktowany jako „psychologiczne zjawisko u ludzi poważnych u których o dobrej wierze wątpić nie można, którzy czasem zupełnie przemieniają to, co się im powiedziało". Niechaj O. Generał usunie zniekształcenia O. Siwka, a jego główna idea apologetyczna i strategia rozsypuje się w gruzy. Jakże więc można mówić o tym, że to jest nieświadome i niecelowe?

Jak bardzo zaś odpowiedź O. Siwka zrośnięta jest z tym właśnie planem antytezy pomiędzy jego naukowością i krytycyzmem, a moim obwinianiem go właśnie o tę naukowość i brak niekrytycznej wiary, o tym świadczą te wszystkie recenzje, które w obronie O. Siwka występują; wszystkie one zniekształcają moją zasadniczą tezę, iż się nie wypowiadałem ani za, ani przeciw zjawiskom w Konnersreuth; wszystkie przedstawiają mniej lub więcej wyraźnie O. Siwka jako ofiarę jego naukowego krytycyzmu, mnie zaś jako fideistę. Wszystkie jednym słowem powtarzają błąd zasadniczy i centralny O. Siwka w jego odpowiedzi, pomimo, że został przeze mnie doszczętnie jego własnymi cytatami jak i moimi obalony.

I ja doskonale rozumiem to stanowisko obrońców O. Siwka. Oni muszą iść tym fałszywym torem, na jaki zeszła książka O. Siwka; gdyby z niego zeszli, z tą chwilą punkt 
oparcia całej jego odpowiedzi i całej jego obrony zostanie obalony. Jakże więc celowym było kolejne zniekształcenie moich wszystkich tez przez O. Siwka, skoro tym właśnie zniekształceniem odpowiedź jego stoi lub upada. Krytycy, których tu wyliczyłem, wychodzący ze środowiska Ojców, na swój sposób tylko potwierdzają to, co powiedziałem.

Dlatego O. Generał mnie zrozumie, że nie mogę przyjąć żadnego zarzutu, iż krzywdzę O. Siwka, przeciwnie muszę stwierdzić, że to O. Siwek swoją metodą wyrządził wielką krzywdę nie tylko mnie, nie tylko prawdzie, ale samemu Zgromadzeniu, w szczególności uniwersytetowi, którego jest członkiem.

Takie jest przynajmniej moje najgłębsze przekonanie. Dlatego w sformułowaniu moich zarzutów moralnych, jakie uczyniłem O. Siwkowi po tym wszystkim sądzę, że nie może być mowy „tylko o pewnych niedokładnościach, które się wkradły”.

Co do krzywdy wyrządzonej mnie, to jak widzę z listu, Ojciec Generał nie kładąc nacisku na istotę przewinienia O. Siwka w zniekształceniu moich tez, nie może się też i dopatrzyć na czym wina główna polega. Oto polega ona przede wszystkim na tym, że O. Siwek, jak to wykazałem w kwestii cudów i innych podobnych, przedstawia mnie od początku do końca w swej książce na podstawie zniekształcenia moich cytatów, przez ciągłe kładzenie kropki nad „i”, jako fanatycznego i bezkrytycznego obrońcę Konnersreuth, przez co odebrał mi prestiż naukowy. Było to już logiczne następstwo choć może niezamierzone jego planu. Bo któż - pytam - weźmie do ręki książkę naukową autora, który się sprzeciwia badaniu naukowemu, który w imię bezkrytycznej wiary w cudowność uzdrowienia zwalcza ostrożność naukową swego oponenta?

Może O. Generał sądzić będzie, że ja tu przesadzam. Odpowiem konkretnym przykładem. Byłem właśnie w roku zeszłym w Krynicy, kiedy się ukazała książka O. Siwka. Wyczerpany fizycznie, a przy tym wciągnięty zupełnie w pracę o życiu Chrystusa, nie miałem w ogóle ochoty odpowiadać. Ale wtedy jeden z XX. Biskupów tam obecnych jak i kapłani z rozmaitych stron Polski i to najpoważniejsi wśród nich, przynaglali mnie do odpowiedzi mówiąc, że jeżeli nie dam na książkę O. Siwka odpowiedzi, to przypieczętuję wszelki mój prestiż naukowy. Ja jeszcze i wtedy nie zwracałem dostatecznej uwagi na to, aż dopiero zaczęły mnie dochodzić głosy z Warszawy o osobach, które dotąd czytały chętnie moje pisma, a teraz pod wpływem lektury O. Siwka odwracały się od nich z odrazą, jako od autora fanatycznie i bezkrytycznie naiwnego.

Z tego prestiżu naukowego dla siebie, mógłbym wprawdzie zrezygnować, gdyby niepotrzebny był dla mojego dzieła o życiu Chrystusa, które właśnie zacząłem wydawać. I wówczas faktom i namowom dałem się przekonać i lubo ze wstrętem wewnętrznym chwyciłem się pracy ponad moje siły fizyczne. Jeżeli O. Generał biada nad zdrowiem O. Siwka, to chyba wolno mi o tym wspomnieć, iż odpowiedź taką metodą, jakiej się chwycił O. Siwek, niezgodną z prawdą i obiektywną wiedzą, przyczyniła się niemało do podkopania mojego zdrowia nie tylko z powodu pracy nadmiernej, ale i dotkliwego bólu, bo przyzna mi Ojciec Generał, że przeciskanie się przez gąszcza, w których rafinowana sztuka zastępowała prawdy, było dla mnie czymś nad wyraz bolesnym. To, że mi O. Siwek napisze teraz, że nie myślał mnie obrazić, to chyba nie jest żadnym odpowiednikiem za tę krzywdę, jaką mi wyrządził. 


\section{Ton mojej książki}

Ojciec Generał charakteryzuje ton mojej książki, jako napisaną „z gryzącą ironią, cierpkim sarkazmem, zgryźliwymi porównaniami”.

Muszę zaznaczyć, że Najprzew[ielebniejszy] O. Generał uczyniłby bardzo dotkliwą krzywdę mojej pracy, gdyby ją rozumiał tak, jakby była jednym ironizowaniem książki O. Siwka. Kto uważnie przeczytał moją książkę ten wie doskonale, że na tych około czterystu stronicach dotknąłem i wedle moich słabych sił rozwiązałem wszystkie problemy związane z Konnersreuth z obiektywnością, powiedziałbym, z pewną wyłącznością, w której znika niemal do zera sama praca O. Siwka. I to był wzgląd, dla którego Niemcy tak gwałtownie napierali o tłumaczenie tej książki; sama polemika z O. Siwkiem mało ich interesowała, ale przedstawienie krytyczne ze stanowiska naukowego zjawisk w Konnersreuth, to miało dla nich główną siłę pociągającą. Jeżeli zaś O. Generał mówi o ironii, to niechaj zechce przyjrzeć się dokładnie tym miejscom, w których te uwagi, jakie O. Generał nazywa ironicznymi, są pomieszczone; przekona się wówczas, że tych kilka uwag na rozciągłości około czterystu stron druku głównie sprowadzić należy do odpowiedzi na ironiczne uwagi O. Siwka.

I pytam, jak można $\mathrm{z}$ ironią rozprawić się w sposób poważny, jak można inaczej ją potraktować, jeżeli nie ironiczną uwagą?

Użyję tu pewnego zwrotu z Pisma św. z góry się zastrzegając, że się posługuję sensem ogólnym tego zwrotu; określenia zaś w cytacie „głupi” nie stosuję do O. Siwka zupełnie. Otóż ten cytat opiewa: Odpowiedz głupiemu wedle głupstwa jego. Cytat ten tylko w tym znaczeniu ma przystosowanie do O. Siwka, że na sposób wprost z cyniczną ironią atakowania mnie, musi być też i odpowiedź charakterem swoim do takiego sposobu dostosowana i dostrojona.

Jeżeli O. Generał miałby czas przejrzeć te bardzo nieliczne miejsca w mojej książce, które nawet nie są w ścisłym tego słowa znaczeniu ironiczne, przekona się wówczas, że te wyjątkowe miejsca są tylko odpowiedzią na ironię O. Siwka. Ażeby nie obciążać tekstu przytaczam w dopisku niektóre teksty ironicznej aluzji do mnie, graniczące nieomal z cynizmem. Niech O. Generał do tego raczy doliczyć te wszystkie miejsca, w których O. Siwek daje mi lekcje logiki, przytaczając w języku łacińskim nazwy logicznego rozumowania i wytykające mi błędy popełnione przeciw temu rozumowaniu! Jakże takie ustępy nie miały mnie najdotkliwiej zadrasnąć i zaboleć!

Sądzę, że najlepszą ilustracją słów moich będą cytaty, których choć parę dla przykładu przytoczę. Oto co pisze O. Siwek: „Nikt nie buduje na samej tylko czystej «możliwości». Możliwym jest, że gdy wyjdę na ulicę, spadnie mi dachówka na głowę i uśmierci mnie. Lecz gdyby ktoś dla tej «możliwości» zaryglował «się w domu i powziął decyzję, iż przez całe życie już nigdy więcej głowy z domu nie wychyli - to każdy powie: najwyższy czas by go zaryglować w domu zdrowia»".

"A przecież innych stygmatów nie pokazuje nikomu” („Aten[eum] Kapł[ańskie]”, luty, str. 112). Odpowiadam na to: Jeszcze by tego potrzeba, by pokazywała innym stygmat boku! Wtedy by się już naraziła na nowy zarzut: „niemoralności!” (str. 86). 
„Czy zniekształcenia obrazu Teresy Neumann nie dokonują raczej ci, co ex post, tj. z przyjęcia za «nadprzyrodzone» dzisiejszych jej wizyt retuszują skrzętnie jej obraz moralny i fizyczny z wszelkich skaz, tylko in ordine logico godzą się na to, że ona ma swoje usterki, ma swoje wady, aby ją do nadprzyrodzonych jej darów dostroić..?” (str. 98).

„Wszyscy chyba nieraz chorowaliśmy. Ale nie wszyscy złościliśmy się na lekarza za jego diagnozę. Nie wszyscy mściliśmy się za nią na nim po jego odejściu! Nie wszyscy przedrzeźnialiśmy go za to... Nie wszyscy w czasie choroby jesteśmy nieznośnymi. Nie wszyscy knujemy na serio plan ucieczki ze szpitala... Proste nawet pielęgniarki umieją wyróżnić wśród swoich chorych: osoby «nerwowe» - w naszym języku: «osoby emotywne» - od osób nienerwowych. Nie wszystkich chorych mianem «nerwowych» darzą" (s. 67).

I co powiedzieć o ustępie 3-cim wyżej przytoczonym? Przecie ten ustęp jest wprost osobistą obrazą moją, jest wprost obrazą mojego moralnego charakteru, iż co innego myślę, a co innego piszę. Niech do tego doda $\mathrm{O}$. Generał te zarzuty, iż ja nie mam pojęcia o tym, co nauka Kościoła głosi o proroctwach, a przekona się, jak pobłażliwą jest obrona O. Siwka w tych słowach: „Mogło mu się wymknąć ostrzejsze słowo, ale to są rzeczy, które się w dyskusji łatwo zdarzają!"

Tu zarazem jest odpowiedź na twierdzenie O. Generała, iż „są nierówne szanse w rozprawie między mną a nim", gdyż jak pisze O. Generał „ja się znajduję w warunkach bez porównania lepszych niż O. Siwek, który choćby mu dozwolono pisać, nie mógłby ze względu na godność biskupa tak otwarcie pisać, jak Wasza Ekscelencja”.

Czy po tych dowodach może kto powiedzieć, że O. Siwek krępował się względami na mnie? Czyż komu mógł więcej powiedzieć ironicznych i cynicznych uwag, aniżeli mnie uczynił w swej odpowiedzi? Następuje tu cały szereg ustępów naukowo zupełnie nieuzasadnionych - ale mniejsza o to - ustępów, w których O. Siwek raz po raz przytacza nazwiska łacińskie z logiki, ażeby mi wykazać, że ja nielogicznie myślę i że błędy logiczne raz po raz powtarzam. Czynione są te zarzuty w formie, która sama za siebie mówi.

Jeżeli ks. Bogdanowicz w artykułach "Gazety Kościelnej” (nie wchodzę w ich meritum) posłużył się literalnie tą samą metodą wobec O. Siwka, jakiej on użył wobec mnie i zaczął wytykać błędy jego przeciw logice, to wystarczyło to, aby wywołać u O. Generała najwyższe oburzenie. Jeżeli tak się jest czułym i wrażliwym na tego rodzaju metody bądź co bądź uzasadnione, to cóż dopiero powiedzieć o tej metodzie stosowanej do mnie, której bezzasadność wykazałem w mojej książce. Niechże do tego doda O. Generał jeszcze to bawienie się i rozkoszowanie złośliwe w zarzucaniu mi nieznajomości elementarnych zasad wiary i mistyki, również zupełnie nieuzasadnione, jak to wykazałem obszernie, to łatwo zrozumie O. Generał, że te moje nieliczne aluzje były tylko prostym następstwem i koniecznym następstwem ataków ironicznych, a nawet cynicznych O. Siwka na mnie. Powiadam: następstwem koniecznym; albowiem podobne ataki w odpowiedzi nie pozwalają się brać na serio; jedyną metodą odpowiedzi na nie jest właśnie taka, jaką ja dałem. Dlatego uważam za jednostronność w tym problemie zupełną, jeżeli O. Generał widzi jedynie tylko skutki metody stosowanej przez O. Siwka, a sprawcę samego okrywa i przykrywa tak, jak gdyby on ze swej strony był pod tym 
względem niewiniątkiem; i jak gdyby nie on właśnie wywołał te ustępy w mojej książce i ich nie spowodował, które O. Generała tak gorszą i które, niestety, próbuje rozciągnąć O. Generał na cały charakter mojej tak obiektywnej i tak spokojnej, rzeczowej dyskusji o zasadniczym problemie stygmatyzacji.

\section{Reklama}

Co do reklamy pisze O. Generał: „...w pismach najróżniejszych odcieni, politycznych, naukowych, popularnych; w miesięcznikach, tygodnikach, pismach codziennych, przedstawia się O. Siwka pod względem moralnym i intelektualnym w jak najgorszym świetle, aby go zniszczyć - nie mogę znaleźć innego wyrazu - w opinii publicznej".

Otóż przede wszystkim na wstępie zaznaczyć muszę, że na te przeróżne recenzje, o jakich $\mathrm{O}$. Generał pisze, ja bynajmniej nie wpływałem; ja nawet nic nie wiedziałem, że się one pojawić mają. Wyjątek stanowi artykuł ks. Bogdanowicza, o którego pojawieniu się wiedziałem, chociaż zaznaczam wyraźnie, że ani na sam pomysł, ani na treść jego nie wpływałem. Sądząc z listu O. Generała powstało istne zatrzęsienie krytyk, które wszystkie godzą w O. Siwka i wszystkie chcą go zniszczyć zupełnie. Tymczasem sądzę, wystarczy samo zregestrowanie tych krytyk, aby się przekonać, jak ich bardzo mało; na palcach jednej ręki zliczyć je można wszystkie.

Nie wliczam tutaj krytyki, która jest odpowiedzią nie O. Siwkowi, ale recenzentowi O. Siwka, podpisującemu się literami J.N. Choć już jest wiadomym, kto się pod tym pseudonimem ukrywa, to jednak tylko bezprzykładny sposób obrony O. Siwka wywołał artykuły przeciwne. Co się zaś tyczy jednak pism innych, to jest rzeczą zrozumiałą i naturalną, iż po pojawieniu się mojej książki każde pismo uważało za swój obowiązek pomieścić recenzję o tej książce jako napisanej przez biskupa, zawierającej prawie 400 stron druku i zajmującej się problemem ściśle naukowym, ale bardzo aktualnym ze stanowiska mistyki, psychopatii etc. To tylko „Przegląd Powszechny” pozwala sobie na luksus, ażeby milczeniem zabić książkę, jak na przykład książkę moją o życiu Chrystusa: „Od Betlejem do Nazaretu”, pracę całego mojego życia, o której nie pomieścił ani wzmianki przez dwa lata, podczas gdy o lada dewocyjnej książeczce rozpisuje się szeroko. Każde z pism uważa wprost za swój obowiązek krytykę taką napisać, ale kto te krytyki przejrzy ten nigdy nie powie, iż one zmierzają do zniszczenia O. Siwka. Przejdźmy je po kolei.

Pokazała się krytyka w „Ateneum [Kapłańskim]” napisana przez ks. prof. Steuera, która przecie w tym piśmie, w którym się pojawiły moje artykuły z natury rzeczy być musiała; to chyba każdy zrozumie. Pojawiła się w „Przeglądzie Katolickim” krytyka Czarneckiego mojej książki, ale w tymże samym piśmie napisana przez tegoż autora pojawiła się życzliwa bardzo ocena książki O. Siwka. Autor podpisał się pseudonimem Roicki. Pokazała się krytyka w „Szkole Chrystusowej” napisana przez dominikanina O. Fica, również po poprzedniej krytyce bardzo sympatycznej w całości dla O. Siwka.

Pozostaje poza tym krytyka dość oględna i delikatna, napisana zdaje się pod pseudonimem Szary w „Kurierze Warsz[awskim]”. Tyle wszystkiego. 
Artykuły w „Gazecie Kościelnej” napisane przez ks. Bogdanowicza, które by się raczej nadawały do miesięcznika, nie zajmują się właściwie moją książką, ani nawet bezpośrednio nie są krytyką książki O. Siwka, tylko przedstawiają studium ze stanowiska logiki książki O. Siwka, zupełnie analogicznie z jego pracą w odniesieniu do mnie, jak to już gdzie indziej wskazałem.

A więc gdzież tu jest ta masa istna tygodników, miesięczników, pism codziennych najrozmaitszych odcieni, o jakich Najprzew[ielebniejszy] O. Generał pisze. Jak zaś różnią się te krytyki od krytyk po tamtej stronie! Najpierw liczebnością swoją. Ile to krytyk pojawiło się w „[lustrowanym] K[urierze] C[odziennym]”, którego rozpowszechnienie jest olbrzymie, że w żadnym stosunku nie stoi do tych krytyk przeważnie zamkniętych w pismach fachowych przez ogół nieczytanych. Charakter tych krytyk jakże jest odmienny od krytyk po tamtej stronie! Krytycy po stronie O. Siwka będący w bezpośredniej łączności z Ojcami [Jezuitami], zamiast oddać myśli moje dosłownie, wiernie, wszystkie co do jednej fałszują moje zasadnicze stanowisko i zmieniają je doszczętne przedstawiając mnie, jak to już pisałem gdzie indziej, wprawdzie nie pod względem moralnym, ale pod względem intelektualnym jak najujemniej. Tymczasem jeden rzut oka na krytyki mojej książki wykazuje, że wszyscy recenzenci przedstawiają obiektywnie rzeczy tak, jak one stoją, nawet nie wyjawiając swojej osobistej opinii jaką mają. W ten czy ów sposób streszczają poglądy w książkach zawarte. Krytyki po tamtej stronie biją i uderzają z tyłu, gdyż ich autorzy nie odkrywają przyłbicy i nie kryją się za pseudonimy; kiedy tymczasem wszyscy krytycy mojej książki występują z otwartą przyłbicą i podpisują swe nazwiska. Po tamtej stronie jedno tylko nazwisko jest podpisane p[ana] Szczepańskiego, który streszczając książkę O. Siwka, rozpowszechniał ogromnie po wszystkich częściach nie tylko Polski, ale i świata przekonanie, że już „Koniec legendy Konnersreuth" i uderzał zarazem na mnie, pisząc o mym pogromie i mej przegranej.

Niechże teraz Najprzew[ielebniejszy] O. Generał sam zechce zestawić bilans tych krytyk po obu stronach, a przekona się, że to, co w liście do mnie pisze nie odpowiada faktom zupełnie. To nie O. Siwek, ale ja raczej byłem szarpany po całym świecie przy współudziale pośrednim czy bezpośrednim Ojców [Jezuitów].

Jakże się znęca na przykład krytyk ze Zgromadzenia Ojców w „Czasie” i „Dzienniku Pozn[ańskim]" nade mną, z pogardą wyrażając się także o krytykach mojej książki i wszystkich nas kwalifikując do obozu ludzi ciemnych, zacofanych, bezkrytycznych, niezdolnych ocenić wielkiego światła profesora Gregorianum, którym nowe światło zaświta przez nową encyklikę Ojca św. o wiedzy chrześcijańskiej. Ile u tego autora pogardy lekceważącej, wprost cynicznej, która dochodzi aż do umyślnego ukłucia krytyka w samym tytule. Tak na przykład O. Fic, dominikanin, jest uczonym, który habilitował się na krakowskim uniwersytecie i który skończył teologię w Lowanium. Ażeby go zlekceważyć, ażeby pokazać, że brał się nie do swoich rzeczy, autor pisze o nim, że jest „geografem" tylko.

A teraz pozwolę sobie zadać pytanie, kto to właściwie spowodował w ogóle krytyki ujemne dla O. Siwka? Czy to nie on sam przede wszystkim? Przecie on swoją pierwszą książkę przez podanie nieprawdziwych szczegółów o Konnersreuth wprowadził w błąd 
tych uczonych, którzy mu zawierzyli i echa ujemnych krytyk o jego książce dadzą się sprowadzić do reakcji przeciwko podobnemu wprowadzeniu w błąd opinii. Tak było z krytyką Czarneckiego, który czuł się skompromitowany swoją pierwszą pochwałą O. Siwka; podobnie było z krytyką uczonego tak poważnej miary jak ks. prof. Steuera.

I kto, pytam, w ogóle zawinił, że książka O. Siwka druga, tj. odpowiedź mi dana, zeszła na forum publiczne i stała się przedmiotem publicznej krytyki? Przecie nikt inny w tym nie zawinił, jak tylko Ojcowie [Jezuici], a w szczególności O. Siwek; bo jest przecie przyjętym w świecie literackim, że się daje odpowiedź w tym piśmie, w którym się pojawiła krytyka. Krytyka pracy O. Siwka pojawiła się w „Ateneum [Kapłańskim]”; rzeczą już naturalną kurtuazji i lojalności wobec mnie zwłaszcza w wypadku tak nowym, jakim jest polemika zakonnika z biskupem, należało odpowiedź pomieścić tak samo w „Ateneum [Kapłańskim]”. Tymczasem pod zupełnie błahym pozorem, że „Ateneum [Kapłańskie]" nie chce dostarczyć korekty do Rzymu, puszcza O. Siwek odpowiedź na szerokie fale publicznej dyskusji.

Gdyby przynajmniej jeszcze wtedy wydał swoją odpowiedź jako manuskrypt, uniknęłoby się recenzji publicznej!

Ojcowie krakowscy czuli całą niewłaściwość wydania takiej książki, rozumieli, że polemika zakonnika z biskupem, którego traktuje w sposób niebywale lekceważący wywołać może tylko zgorszenie ponad forum publicznym nieprzygotowanym nawet naukowo do takiej pracy. Niestety, przychodzi nakaz z Rzymu, ażeby wbrew opinii Ojców krakowskich książkę wydać!

Wspomina O. Generał o ustępie mojego listu do Ks. Prymasa, w którym mu piszę, że mam druzgocące dowody przeciw O. Siwkowi. Mam je istotnie; ale O. Generał czyni mi wyrzut, że chcę O. Siwka zniszczyć. Lecz zarzut O. Generała jest niesłuszny, albowiem już to samo, że tych dowodów nie pomieściłem w mojej książce, że wolałem zamiast uderzyć wprost dokumentami jakie posiadam, czynić okrężną a bardzo dla mnie uciążliwą drogę, świadczy o tym, do jakiej miary oszczędzałem O. Siwka. Oczywiście wobec zapowiedzi O. Generała obecnej, o jakiej pisałem, wobec zapowiedzi późniejszego ukazania się pracy O. Siwka, trudno chyba ode mnie żądać, ażebym w obronie własnej nie wystąpił z dokumentami jakie posiadam.

Pisze mi O. Generał, iż ks. Bogdanowicz dla własnej reklamy napisał te artykuły. Otóż przed pojawieniem się tych artykułów, ks. Bogdanowicz jakkolwiek miał przygotowaną odpowiedź O. Siwkowi od września, to jednak nie publikował jej wcale; liczył się bowiem z tym, że moim pragnieniem jest, aby sprawę całą załatwić w drodze ile być może pokojowej i wstrzymać się od wszystkiego, co by z mojej strony wpływało drażniąco na tok krytyki. Tę wstrzemięźliwość ks. Bogdanowicza podnoszę z uznaniem, bo nie była ona wywołana zakazem moim, ale własnym jego poczuciem. Niestety, tak jak polemikę publiczną wywołało puszczenie odpowiedzi O. Siwka na drogę księgarskich publikacji, podobnie rozbudzenie krytyki w kołach mi bliskich zostało wywołane artykułami Ojców. Gdyby choć krytycznymi, choć naukowymi artykułami!

Nie w pismach fachowych i kapłańskich, ale w dziennikach zostają ogłoszone niesmaczne reklamy tak dla O. Siwka, jak dla jego pracy z aluzjami obraźliwymi do tych, 
którzy by się o nich z krytyką [zwracali] do mnie, jako do bezkrytycznego poszukiwacza cudowności w zjawiskach.

Należy więc to ustalić, że artykuły ks. Bogdanowicza były z umysłu w tym tonie utrzymane, $\mathrm{w}$ jakim nastąpił atak na mnie, ażeby raz nareszcie skończyć $\mathrm{z}$ takimi metodami polemiki i walk.

Nie myślę wchodzić w meritum artykułów ks. Bogdanowicza, stwierdzam tylko, że w posiadaniu archiwum dotyczącego Konnersreuth są moi kanonicy i że ks. Bogdanowicz swoją pracę pomieścił zupełnie na własną odpowiedzialność, a ja ze swej strony ani na jej pomysł, ani na jej treść w niczym nie wpływałem.

Na końcu dodaję jeszcze jedną uwagę. Otóż przed wydaniem mojej książki dałem manuskrypt trzem osobom obdarzonym niezwykłym taktem w takich kwestiach, prosząc każdą z nich, ażeby przejrzała cały manuskrypt i zwróciła moją uwagę na każde miejsce, w którym zwracałbym się w sposób osobisty przeciwko O. Siwkowi. Niechże w tym ma Ojciec Generał dowód, jak bardzo mi zależało na tym, aby osobiście O. Siwkowi nie ubliżyć i nie odpłacać mu równą monetą.

Oczywiście każdy ma właściwy sobie sposób polemizowania; u mnie zaś występuje on zawsze w sposób żywy i bezpośredni, ale muszę powiedzieć, że jeżeli O. Generał uważa ton mój w polemice za ostry, to jako uzasadnienie takiego tonu podaję metodę O. Siwka i ponadto sposób, w jaki on się obszedł w swej drugiej pracy z Teresą Neumann.

Jeszcze przed ukazaniem się mojej krytyki w „Ateneum [Kapłańskim]”, zanim O. Siwek wiedział, co ja napiszę, już się poważył w liście do mnie pisanym po moich odczytach w Krakowie wydrwiwać zarówno Teresę Neumann, jak i mnie samego. Teresę Neumann w liście do mnie nazywa: „ta dziewczynka”; do mnie czyni aluzję o moderniźmie etc., ale co najważniejsze w jednym ze swych listów już mi zapowiada, w jakim kierunku posunie się jego ewentualna krytyka, jeżeli się poważę ze swej strony poddać krytyce jego pracę. Pisze on: „będę musiał wytoczyć cały szereg punktów delikatnych, mniej więcej nawet, osobistych osób wmieszanych w kwestię Konnersreuth"!

Jakkolwiek te słowa możnaby jeszcze uważać za zbyt ogólnikowe, to w związku z innymi szczegółami było to jasne, iż O. Siwek grozi mi w razie podjęcia się rozprawy z nim pomszczeniem się za to na Teresie Neumann przez puszczenie rozprawy na osobiste kwestie związane z Teresą Neumann. Może użyłem zbyt drastycznego słowa: pomszczenia się. Ale trudno mi inaczej określić związek pomiędzy groźbą O. Siwka a między ewentualną moją rozprawą, której jeszcze wcale nie znał, gdyż się wówczas jeszcze nie ukazała.

Bądź co bądź zapowiedź swoją O. Siwek dotrzymał. Popełnia on niedyskrecję w najwyższym stopniu, gdy publikuje rewelacje konsystorza regensburskiego i jak się to pokazuje z listu biskupa Buchbergera, nieprawdziwe. Wyciąga szereg faktów kompromitujących Teresę Neumann opartych o anonimy, a jak się pokazuje, nieprawdziwych, w końcu sam jeszcze od siebie dodaje ustępy, które swymi domyślnikami i powiedziałbym swoją pikanterią uderzają z ironiczną złośliwością w najdelikatniejszą stronę charakteru Teresy Neumann, bo w stronę moralną. 
Pozostawiam osądzeniu O. Generała czy podobny sposób atakowania biednej, bezbronnej osoby, który się opiera o anonimy, a ignoruje świadectwa naocznych świadków, jak mnie i ks. biskupa Lisowskiego, i dokumenty drukowane, może się pogodzić z określeniem, jakiego O. Generał używa, iż „mu zawsze tylko dobrą wiarę przypisać można”? Dla mnie przynajmniej taki sposób postępowania i krytyki z dobrą wiarą pogodzić się nie da.

Otóż, proszę Ojca Generała, taka metoda moralna mówi sama za siebie i musi wywołać w każdym choćby najobojętniejszym dla sprawy Teresy Neumann nie tylko niesmak, ale wprost oburzenie. Takie obryzganie błotem Teresy Neumann było dla mnie jeszcze i z innej przyczyny wprost czasem wstrętnym i oburzającym, bo przecie teraz właśnie Ks.Ks. Biskupi bawarscy zlecili tę sprawę ks. b[is]k[u]p[owi] Buchbergerowi i on się nią bliżej zajmuje. Wiem z jego własnych słów rozmowy z nim przeprowadzonej, jakie on ma wysokie wyobrażenie o moralnym charakterze Teresy Neumann, a zresztą wyrażał się o tym publicznie w swych kazaniach.

Otóż rzucić postać Teresy Neumann z takim cynizmem, jak to uczynił O. Siwek w chwili właśnie badań Kościoła na pastwę protestantyzmu i racjonalistów, to jest czyn, który musi wywołać oburzenie.

Jeżeli teraz zbiorę razem wszystkie punkty obrony O. Siwka przez O. Generała, to przychodzi mi z przykrością stwierdzić, że ani jednemu punktowi tej obrony słuszności przyznać nie mogłem, choć byłem gotów rad to uczynić. Naturalnie, zawsze najsłabsze są te obrony, które zamierzają wszystko obronić i wszystko wymówić.

Ojciec Generał pragnął w swym szlachetnym, a dla O. Siwka - jak twierdzą zresztą wszyscy - aż do ojcowskiej słabości wyrozumiałym sercu, zatrzeć wszelką skazę swojego duchownego dziecka, bo nawet tam, gdzie coś przyznaje, równocześnie broni i zasłania.

A więc jeżeli O. Siwek z katedry atakował mnie z kpinami, to go broni O. Generał, że powiedzenie o kimś, że nie jest w obcym fachu bity, nie ubliża nikomu. I już na poczekaniu jest przesłonione ostrze winy O. Siwka, który właśnie kpił ze mnie, że biorę się do pisania nie mając pojęcia o rzeczy. Jakaż to wrażliwość jest u O. Generała na krytykę obecną O. Siwka, która uderza w jego prestiż intelektualny, a jaka wprost dziwna niewrażliwość nie już na rzeczową krytykę, ale na kpiny z umysłowości mojej.

Ataki O. Siwka gwałtowne, cyniczne, ironiczne to są tylko u niego nerwy. I nie jest zupełnie znany O. Generałowi ten gwałtowny ton w atakach O. Siwka tak dobrze znany redakcjom pism, z którymi się stykał, tak że aż mnie jedna redakcja wprost ostrzegała przed jego bezwzględnością wobec przeciwników.

Ironia i cynizm przebijające się poprzez karty jego pracy nie są dostrzegalne w obronie O. Generała i redukują się do rzeczy zupełnie nieznacznej, jakiegoś czasem silniejszego słowa!

Jego zniekształcenie sprytne, celowe wszystkich tez moich to tylko jakieś przeoczenie, które jest wpływem subiektywnego niedopatrzenia. Walczy się i szermuje z O. Siwkiem bronią jego argumentów, to się tym samym rozchodzi z przykazaniem miłości, bo tylko ten, co wszystko pojmuje, ten wszystko przebacza. Polemika z nim, odpowiedź na jego zarzuty nie odłącza się nigdy od wyrządzenia mu dotkliwej krzywdy etc., etc. 
Daruje O. Generał, że w taki ostateczny bilans zbieram charakter całej obrony i że z tego właśnie powodu muszę ją uważać za niewystarczającą. Dla sentymentu szczególniejszego ze strony Ojca Generała dla O. Siwka mam pełny szacunek, ale musiałem jasno podnieść to wszystko, co ten sentyment zakrywa, przez ten sentyment jest zamazane i zakryte.

\section{Konkluzja}

A teraz przystępuję do ostatecznej konkluzji. Najprzew[ielebniejszy] O. Generał przez pośrednictwo Ks. Prymasa podstawił mi myśl jakiegoś publicznego oświadczenia z mej strony. Odpowiedziałem na to Ks. Prymasowi, iż uważam ten projekt za bardzo trudny do zrealizowania i przedstawiłem powody tej mojej odmowy. W ogóle nawet z zasadniczego punktu uważam, iż tam, gdzie się kwestie rozstrzyga na drodze publicznej dyskusji, nie ma miejsca na jakiekolwiek oświadczenie. Ale mimo to, ażeby dogodzić O. Generałowi nie byłem w zasadzie przeciwny podobnemu rozwiązaniu kwestii, mimo całego sceptycyzmu mojego, z jakim się na nią zapatrywałem. Bo ostatecznie to, co jest trudne, jeszcze nie jest dlatego niemożliwe. Trudno z pewnością wymyślić sobie racje jakiegokolwiek mojego oświadczenia, jak gdyby półoficjalnego. Już to samo zakrawałoby na rektraktację moją.

Ale kto wie, czy na przykład w drodze wymiany listów, z których pierwszy byłby listem O. Siwka pisanym do mnie, nie mógłbym w odpowiedzi O. Siwkowi powołać się na te wszystkie dodatnie strony w moim dziele, w których pisałem o nim. Z tego powodu przedstawiwszy Ks. Prymasowi moje trudności, zdałem ostateczny sąd w tej sprawie w jego ręce. Oczekiwałem nawet, iż po porozumieniu się Ks. Prymasa z O. Generałem w Rzymie i po rozważeniu moich trudności, projekt ten przybiera konkretne formy.

Tymczasem zamiast odpowiedzi Ks. Prymasa otrzymuję list O. Generała z którego wnoszę, że O. Generał nie liczy się już zupełnie z pośrednictwem Ks. Prymasa, a więc i z moim oświadczeniem, jakie Ks. Prymasowi złożyłem, ale sam bierze sprawę w rękę bezpośrednio i dyktuje mi warunki oświadczenia.

Przyznaję, że tym sposobem postępowania zostaję w najwyższym stopniu zaskoczony. Sądzę, że ze względu na osobę Ks. Prymasa i ze względu na mnie, tego rodzaju obrotu rzeczy nie można nazwać ani pożądanym, ani nawet właściwym i odpowiednim. Skoro okazałem moją dobrą i szczerą wolę, skoro w tym duchu rozmawiałem z ks. metropolitą Sapiehą, także z ks. metropolitą Szeptyckim, to należało mi się uszanowanie tego mojego stanowiska i tej mojej godności. Ale pomijam już ten szczegół zupełnie. Obok układu tekstu mojego ewentualnego oświadczenia, które by mi kazało przyznać, iż metody O. Siwka są dobre, podczas gdy je ze stanowiska ogólno-naukowego zwalczałem, znajduje się w tych warunkach jeden ustęp najważniejszy. Mianowicie O. Generał oświadcza, iż nie osiągnąwszy ode mnie potrzebnych dla siebie wyjaśnień, uda się z tą sprawą wprost do Ojca św. Muszę powiedzieć, że takie oświadczenie O. Generała przecina od razu wszelką gotowość z mej strony, ażeby w tej sprawie pójść jak najbardziej na rękę Ojcu Generałowi. 
Albowiem czyniąc cokolwiek pod takim zagrożeniem, ściągnąłbym na siebie co najmniej pozory, iż sam przyznaję się do tego, jakoby w moich książkach było coś takiego, co by dostarczyło materiału do podobnego, wprost niebywałego oskarżenia. Nawet pozoru podobnego ściągnąć na siebie nie mogę.

Wobec takiego postawienia rzeczy przez O. Generała, ja z mej strony oświadczam lojalnie O. Generałowi, że ewentualnie i ja wniosę skargę do Ojca św. na O. Siwka. Skarga ta dotyczyć będzie głównie jego ataku na mnie na katedrze w Rzymie, który wcale tak skromnie nie wygląda, jak go O. Generał przedstawia. Albowiem O. Siwek drwił i kpił ze mnie przed uczniami. Mniejsza o to, czy ta rzecz się rozeszła mniej lub więcej, tu idzie o sam charakter występu, a jeżeli kapłani powracający z Rzymu, jak i zakonnice rzymskie mi donieśli o tym, to chyba nie przejaskrawiam tego faktu, jak to O. Generał sądzi.

Następnie oskarżę O. Siwka o to, że w swej odpowiedzi w sprawie proroctw publicznie uczynił mi zarzut nauki niezgodnej z Kościołem. Albowiem uzależnienie prawdziwości proroctw od istnienia ekstaz, co mi podsuwa O. Siwek jest niezgodne z nauką Kościoła, jest błędne w kwestii tak zasadniczej i pierwszorzędnej jak nauka o proroctwach. Dołączę nadto Ojcu św. dowodów na moralne poniżenie mnie przez O. Siwka, jako łatwowiernego i bezkrytycznego fideistę.

Mogę natomiast złożyć O. Generałowi oświadczenie, które złożyłem ks. metropolicie krakowskiemu dawno jeszcze przed ukazaniem się projektu O. Generała. Oświadczenie to moje składam bez względu na wszelkie ewentualne kroki O. Generała, albowiem one nie są nowe; są tylko powtórzeniem oświadczenia dawnego. Przedstawiłem ks. b[is] $\mathrm{k}[\mathrm{u}] \mathrm{p}$ [owi] krakowskiemu, że jeżeli Ojcowie [Jezuici] ze swej strony nie będą ze mną publicznie walczyć, to wówczas ja nie będę zupełnie poruszał więcej kwestii rozprawy z O. Siwkiem. Nie mogę być odpowiedzialnym za ewentualne krytyki, które by się pojawiły poza mną, choć sądzę, że już są prawie zamknięte, ja jednak nie będę kwestii z mej strony w żadnej formie poruszał. Sądzę, że to jest właściwie zasadnicze i istotne.

Los tedy dalszy dyskusji składam w ręce Ojców [Jezuitów]; od nich wszystko zależy czy sprawa ta zupełnie się uspokoi, czy też, czego nie przypuszczam i czego bym bardzo a bardzo nie pragnął, w dalszym ciągu się zadrażni.

W końcu pozwoli O. Generał na jedną uwagę, którą ten list zamykam. O. Generał pod adresem moim wystosował przestrogę, iż szkoda niezmiernie czasu na takie rzeczy, o jakie dzisiaj spór się toczy. Nie myślę bynajmniej brać O. Generałowi za złe tej admonicji tym bardziej, iż sam ją sobie przedtem czyniłem; ale mógłbym chyba ustnie kiedyś Ojcu Generałowi wyjawić, jak wbrew mej woli wprost byłem party do zajęcia się problemem Konnersreuth, którego już następstwem była nieodzowna rozprawa zasadnicza z O. Siwkiem. Natomiast pozwolę sobie z mej strony już pod adresem O. Generała uczynić pewne spostrzeżenie w tym przeświadczeniu, że mi je O. Generał za złe nie weźmie.

Problem Konnersreuth jest problemem, który dzisiaj wstrząsa światem i jak to zresztą O. Siwek w swej pierwszej książce przyznał, wszystko ma po temu, ażeby świat wstrząsnąć w posadach. Oczywiście to zależy od tego, czy ten problem jest złudą, czy też jest prawdą. Te kwestie musi rozstrzygnąć krytyka naukowa, a ostatecznie Kościół. Ale idzie teraz o to, jakie ma być nastawienie krytyki do tego problemu. Czy można nazwać 
nastawieniem poważnym i obiektywnym takie, jakiego wyrazem była ostatnia praca O. Siwka? On szedł na spotkanie z tym problemem przede wszystkim ze zdumiewającą ignorancją faktów, które są w Konnersreuth, przesądzając o nich z równą nieznajomością rzeczy, jak pewnością siebie; on szedł na spotkanie z tym problemem z uprzedzeniem graniczącym wprost z cynizmem w odniesieniu do samej osoby stygmatyczki; on po prostu ten problem ośmieszył i wydrwił w sposób, w jaki się dotąd nikt z racjonalistów na to nie odważył. On się odniósł do tego problemu przekreślając najwiarygodniejsze świadectwa świadków autentycznych, opierając się li tylko na anonimach.

Nic dziwnego, że książka taka staje się w ręku racjonalistów i protestantów ewangelią $\mathrm{w}$ walce $\mathrm{z}$ nadprzyrodzonym charakterem zjawisk w Kościele i to w chwili, gdy te zjawiska są przedmiotem badań Kościoła. Jeżeli problem ten jest znakiem działania Ducha św., to w takim razie nawet wobec samej tylko możliwości takiego działania podobne nastawienie się jest czymś karygodnym, nie tylko ze stanowiska obiektywności badań naukowych, ale i z przyczyn wrogiego nastawienia się do ewentualnego działania Ducha św. w świecie i do Jego zamierzeń, jakie On przez to zjawisko pragnie wywołać.

Tu już wcale o to nie idzie, czy ten ktoś, kto się wrogo ustawia do problemu nazywa się Siwek i jest profesorem Gregorianum, czy się nazywa Teodorowicz i jest biskupem! To są kwestie osobiste, które zupełnie wobec zjawiska tego problemu znikają; tu idzie o to, iż wobec ewentualnej możliwości, że w tym zjawisku działa Duch św., podobne oporne przeciwstawienie się z góry do tej możliwości obciąża odpowiedzialnością nie tylko badacza, ale w tej chwili i Zgromadzenie jego, o ile ono nie tylko nie widzi win, ale - powiedziałbym - wprost do upadłego ich broni.

Powiedziałem dosyć, może aż za wiele. Niech mi to O. Generał zechce wybaczyć, ale ja naprawdę boję się i drżę o odpowiedzialność O. Generała w tej sprawie.

Przytaczam tu dla przykładu O. Magera, którego O. Siwek przedstawia jako głowę wrogów Konnersreuth. Jak to wykazałem w mej pracy, tak nie jest, jak O. Siwek twierdzi i mam list O. Magera, w którym zupełnie aprobuje to stanowisko, jakie w jego sprawie w mojej książce zająłem. Otóż O. Mager miał tę szlachetną odwagę, że w ostatnim numerze „Benediktiner Bote” pomieścił list pewnej wysokiej damy niemieckiej, katoliczki, która mu szeroko odpowiada o cudownym nawróceniu zatwardziałego protestanta jej męża i jej syna, i wyraża O. Magerowi i ks. Wunderle'mu żal z tego powodu, iż wobec takich widocznych znaków Bożych ciągle zajmują wobec tego stanowiska nieprzyjazny nastrój. O. Mager wyjaśnia w przedmowie do tego listu, iż jego stanowisko jest mylnie nieraz tłumaczone, ale przez podanie treści listu zwróconego przeciw sobie przyznaje tym samym siłę i moc argumentom, jakimi się przeciw niemu posłużyła owa pani, mówiąc o odpowiedzialności przed Bogiem za sposób, z jakim się ktoś do tego problemu zgodnie czy niezgodnie z zasadami zdrowej krytyki ustawi.

To szlachetne stanowisko O. Magera, który nie wahał się rzucić na szalę prestiżu osobistego swojego, ugiąwszy się przed wymową nadzwyczajnych nawróceń, ośmieliło mnie do uczynienia tej uwagi Ojcu Generałowi popartej zdaniem jednego z naszych książąt Kościoła, bardzo osobiście oddanego Ojcu Generałowi.

Na tym mój list kończę. 


\section{Dokument 14}

Oryg.: AFKDOPW, teczka 141: Spuścizna abp. Józefa Teodorowicza, sygn. 1682/65 [5], List o. Włodzimierza Ledóchowskiego SJ do abp. Józefa Teodorowicza, Rzym 6 VI 1937 r.

Rzym, 6 czerwca 1937

Ekscelencjo ${ }^{a}$, Najprzewielebniejszy Księże Arcybiskupie!

Dowiedziałem się dopiero z „Osservatore Romano”88, że Wasza Ekscelencja obchodziła 50-letni jubileusz kapłaństwa. Śpieszę się więc, by złożyć Jej z tej okazji najserdeczniejsze życzenia coraz obfitszych łask Bożych, wsparte biednymi swymi modlitwami i ofiarą we mszy św. Raczy i Wasza Ekscelencja o mnie przed Bogiem pamiętać; coraz ciemniejszy horyzont, a jedynie w Bogu całą swą ufność pokładać można.

Całując z najgłębszą czcią ręce Waszej Ekscelencji pozostaję najniższym sługą

Wł[odzimierz] Ledóchowski SJ

\section{Dokument 15}

Oryg.: ARSIR, bsygn., List abp. Józefa Teodorowicza do o. Włodzimierza Ledóchowskiego SJ, Lwów 19 VI $1937 \mathrm{r}$.

$\dagger$

Przezacny $^{\mathrm{a}}$ Ojcze Generale!

List Ojca Generała sprawił mi prawdziwą i szczególniejszą pociechę. Proszę mi wierzyć, iż życzenia Ojca Generała przesłane mi, były odpowiedzią na potrzebę mojego serca. W liście tym wzniósł się Ojciec Generał nad chwilowe, przypadkowym zbiegiem wydarzeń spowodowane nieporozumienie, a dotarł do tego, co w stosunku do Osoby Ojca Generała i Zgromadzenia Ojców jest w mej duszy trwałe i nieprzemienne. Oceniam to w pełni i jestem Ojcu Generałowi szczególniej za to zobowiązany.

Już jako kleryk byłem w Stanisławowie ${ }^{89}$ jakby w szkole Ojców. Jeszcze dziś brzmią mi w uszach słowa O. Baczyńskiego ${ }^{90}$, który w dniu wigilii, gdy byłem u Ojców, a przywoływano mnie do domu, bym prędzej tam szedł, wypalił mi O. Baczyński naukę w swoim stylu o porzuceniu w kapłaństwie względów na dom i rodzinę. Przesunęły się dziś przed

a Tekst pisany czarnym atramentem na jednej stronicy papieru formatu zeszytowego. W prawym górnym rogu nota ręką archiwisty: „1682/65 [5]”.

${ }^{88}$ Zob. w niniejszej publikacji: J. Wołczański, Korespondencja abp. Józefa Teodorowicza z abp. Adamem Stefanem Sapieha, dokument 22.

a Tekst pisany na 1,5 stronicy papieru formatu A4. W lewym górnym rogu karty tytułowej nota inną ręką: „Metrop[olita] Teodorowicz - Leopol[is]”, w prawym górnym rogu noty inną ręką: „1937” i „Pol. Mai. 1025 bis - V - 64".

89 Stanisławów - miasto wojewódzkie w Małopolsce Wschodniej.

${ }^{90}$ Baczyński Teofil (1816-1886), święcenia kapłańskie w 1845 r. w Zakonie oo. Jezuitów, 1845-1847 nauczyciel gimnazjalny w Nowym Sączu, misjonarz na Śląsku i w Poznańskiem, 1862-1884 rekolekcjonista w Galicji, 1862-1869 administrator par. Stara Wieś, 1883-1886 superior domu w Stanisławowie. Baczyński Teofil, w: EWJ, s. 23. 
oczyma moimi tak niepospolite postacie do jakich lgnąłem - Ojców Bratkowskiego ${ }^{91}$, Tychowskiego ${ }^{92}$, Badeniego, Załęskiego ${ }^{93}$ i Jackowskiego ${ }^{94}$, i innych. Jako młody kapłan nosiłem się nawet z myślą wstąpienia do ojców i w tym celu pojechałem na rekolekcje do Starej wsi ${ }^{95}$. Zmroził mię tylko swoim pozornym chłodem O. Mycielski ${ }^{96}$.

Później byłem przy narodzinach „Przeglądu Powszechnego”, z którym niejednokrotnie współpracowałem. Umyślnie nie wspominam Ojca Generała, chociaż Ojciec Generał dobrze o tym wie, ile sympatii i głębokiego szacunku łączyło mnie z Osobą Ojca Generała. Dlatego z głębi serca przesyłam Ojcu Generałowi najgłębszą podziękę za tak mnie cenny dowód pamięci i przesłane mi życzenia.

Zawsze oddany w czci najgłębszej sługa

† Teodorowicz

Lwów, 19/VI [1]937

${ }^{91}$ Zob. w niniejszej publikacji: J. Wołczański, Listy abp. Józefa Teodorowicza do abp. Józefa Bilczewskiego, dokument 99.

${ }_{92}$ Tychowski Szymon (1841-1915), święcenia kapłańskie w 1868 r. w Zakonie oo. Jezuitów, 1865-1867 wykładowca w Kalksburgu, 1867-1872 i 1874-1880 wykładowca w Tarnopolu, 1881-1882 misjonarz ludowy w Nowym Sączu, 1882-1883 w Łańcucie, 1883-1885 i 1886-1892 w Stanisławowie, 1885-1886 w Czerniowcach, 1892-1893 w Krakowie, 1893-1894 superior w Ławrowie, 1894-1898 przełożony misjonarzy ludowych w Krakowie, 1898-1899 misjonarz w Cieszynie, 1899-1901 superior w Zakopanem, 1901-1915 przebywał w Krakowie. Tychowski Szymon, w: EWJ, s. 705.

${ }^{3}$ Załęski Stanisław (1843-1908), święcenia kapłańskie w 1870 r. w Zakonie oo. Jezuitów, w l. 60. XIX w. pracował w Tarnopolu, 1871-1874 i 1876-1879 kaznodzieja i współpracownik „Przeglądu Lwowskiego”, 1879-1881 wykładowca w Tarnopolu, 1885-1892 superior domu św. Barbary w Krakowie, 1893-1895 superior w Nowym Sączu, 1899-1902 superior we Lwowie, 1902-1908 pracował w Nowym Sączu; autor prac naukowych z historii Zakonu oo. Jezuitów. Zatęski Stanistaw, w: EWJ, s. 780.

${ }^{94}$ Jackowski Henryk (1834-1905), święcenia kapłańskie w 1860 r. w Pelplinie, w 1861 r. wstąpił do Zakonu oo. Jezuitów, 1865-1870 misjonarz w Śremie, 1871-1877 mistrz nowicjatu w Starej Wsi, 1878-1880 misjonarz unitów na Podlasiu, 1880-1881 rektor w Krakowie, 1881-1887 prowincjał Prowincji Galicyjskiej, 1887-1891 rektor w Chyrowie, 1893-1896 superior domu św. Barbary w Krakowie, 1902-1904 rektor w Cieszynie, inicjator powstania periodyków „Misje Katolickie”, „Roczniki Rozkrzewiania Wiary” i „Przeglądu Powszechnego”, animator erygowania Zakładu Naukowo-Wychowawczego w Chyrowie, autor licznych publikacji o tematyce religijno-społecznej. Jackowski Henryk, w: EWJ, s. 234.

${ }_{95}$ Właściwie: Stara Wieś - miejscowość w pow. Brzozów, woj. Lwów; funkcjonuje tam do dziś klasztor oo. Jezuitów.

${ }^{96}$ Mycielski Michał (1826-1906), święcenia kapłańskie w 1861 r. w Zakonie oo. Jezuitów, 1864-1865 wykładowca języków obcych w Tarnopolu, 1865-1872 rektor w Śremie, 1873-1877 sekretarz prowincjała, 1877-1881 i 1887-1893 prowincjał Prowincji Galicyjskiej, 1881-1882 superior domu w Krakowie, 18821883 rektor w Starej Wsi, 1883-1887 mistrz nowicjatu tamże, 1893-1895 dyrektor Apostolstwa Modlitwy w Krakowie, 1895-1897 rektor domu w Tarnopolu, inicjator powstania Wydawnictwa Apostolstwa Modlitwy w Krakowie, autor licznych publikacji religijnych. Mycielski Michat, w: EWJ, s. 447-448. 
A4. Uniwersytet Papieski

Tfand Jana Pawła I 